FACULDADE DE FILOSOFIA, LETRAS E CIÊNCIAS HUMANAS DEPARTAMENTO DE FILOSOFIA

PROGRAMA DE PÓS-GRADUAÇÃO EM FILOSOFIA

\title{
AUTONOMIA E SUAS EXPRESSÕES: \\ A QUESTÃO DA LEGITIMIDADE NA POLÍTICA KANTIANA
}

Rodrigo Luiz Silva e Souza Tumolo 
Rodrigo Luiz Silva e Souza Tumolo

\section{AUTONOMIA E SUAS EXPRESSÕES: \\ A QUESTÃO DA LEGITIMIDADE NA POLÍTICA KANTIANA}

Dissertação apresentada ao Programa de PósGraduação em Filosofia do Departamento de Filosofia da Faculdade de Filosofia, Letras e Ciências Humanas da Universidade de São Paulo, para obtenção do título de Mestre em Filosofia sob a orientação do Prof. Dr. Maurício Cardoso Keinert 
Autorizo a reprodução e divulgaçào total ou parcial deste trabalho, por qualquer meio convencional ou eletrônico, para fins de estudo e pesquisa, desde que citada a fonte.

Catalogaçẵo na Publicaçăo

Serviço de Biblioteca e Documentaçăo

Faculdade de Filosofia, Letras e Ciências Humanas da Universidade de São Paulo

Tumolo, Rodrigo Luiz Silva e Souza

Autonomia e suas expressoles: a questào da

legitimidade na politica kantiana / Rodrigo Lui Silva e Souza Tumolo, orientador Mauricio Cardoso Keinert. - Sao Paulo, 2016.

$111 \mathrm{f}$.

Dissertaçào (Nestrado) - Faculdade de Filosofia, Letras e Ciências Humanas da Universidade de Săo Paulo. Departamento de Filosofia. frea de concentraçao: Filosofia.

1. Autonomia. 2. Legitimidade. 3. Republicanismo. 4. Direito. 5. Politica. I. Keinert, Mauricio Cardoso, orient. II. Titulo. 


\section{FOLHA DE APROVAÇÃO}

TUMOLO, R. L. S. S. Autonomia e suas expressões: a questão da legitimidade na política kantiana. 2016. Dissertação (Mestrado) - Faculdade de Filosofia, Letras e Ciências Humanas. Departamento de Filosofia, Universidade de São Paulo, São Paulo, 2016.

Prof. Dr. Maurício Cardoso Keinert

Prof. Dr. Maria Lúcia Mello e Oliveira Cacciola

Prof. Dr. Bruno Nadai 
À José Luiz e Graça Tumolo, meus pais e maiores incentivadores. 


\section{SUMÁRIO}

INTRODUÇ̃̃

I - MORALIDADE: RELAÇÕES ENTRE ÉTICA, DIREITO E POLÍTICA....................... 17

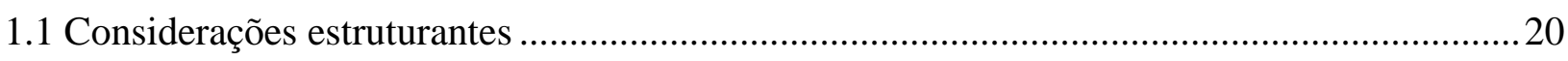

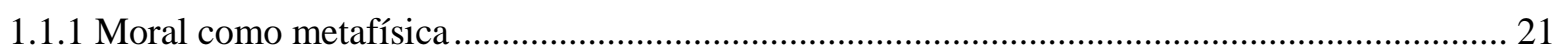

1.1.2. A teoria e a prática: a política como doutrina prática .............................................................. 23

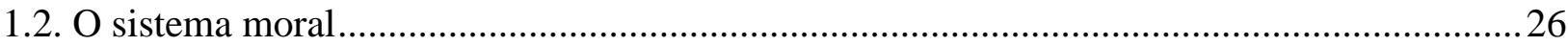

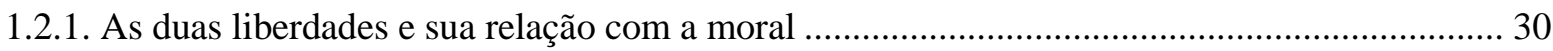

1.2.2. A doutrina universal dos costumes ("Philosophia practica universalis") .................................. 33

1.2.3. Unificando o imperativo categórico: autonomia e reino dos fins ............................................. 36

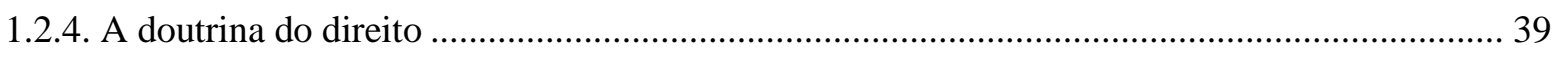

1.2.5.1. Questão incidental: o positivismo jurídico de Kelsen ......................................... 43

1.2.5.2. Questão incidental: a tese da independência do direito......................................... 45

1.3. A coesão do sistema: relações entre a política e a filosofia da história ................................ 48

II - O PERCURSO PELA POLÍTICA .............................................................................................51

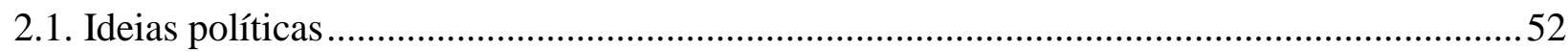

2.1.1. Da passagem do estado de natureza ao estado civil-jurídico.................................................... 52

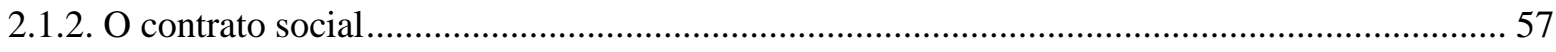

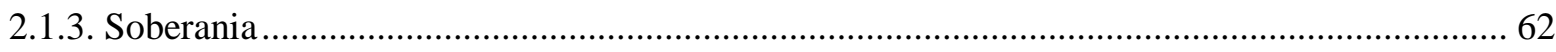

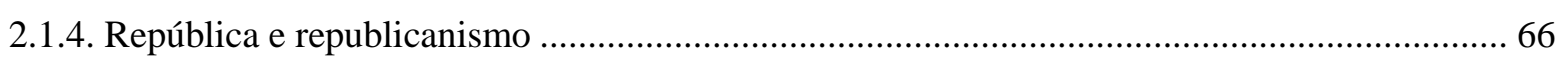

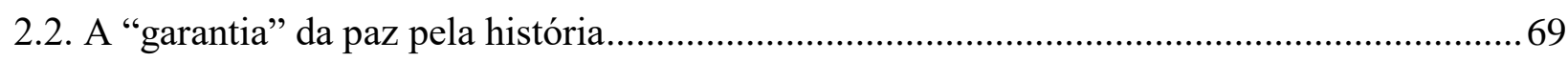

III - O USO PÚBLICO DA RAZÃO COMO AUTONOMIA POLÍTICA ............................ 74

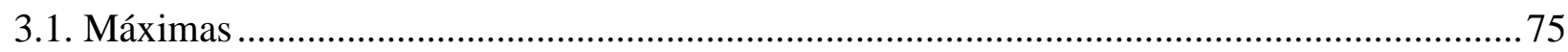

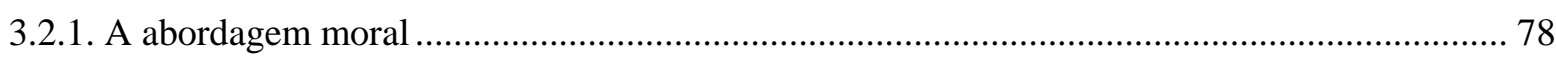

3.1.2. Máximas políticas: harmonizando a política com a moral ................................................... 87

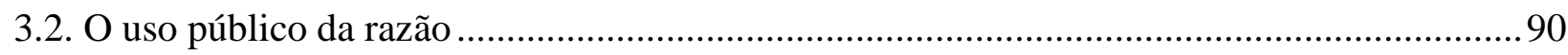

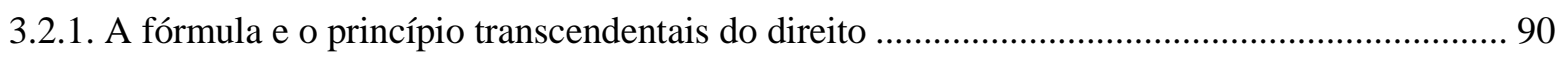

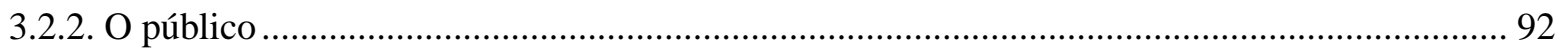

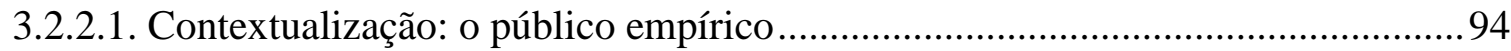

3.2.2.2. O público "a priori" da teoria .......................................................................... 97

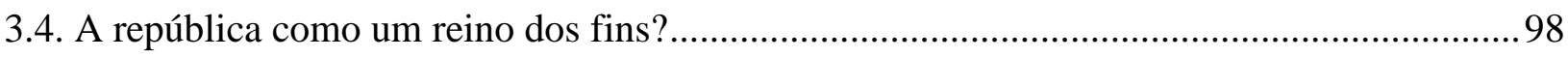

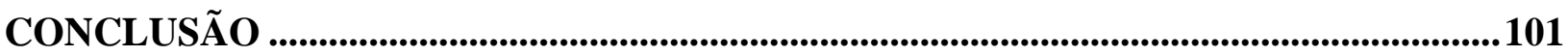

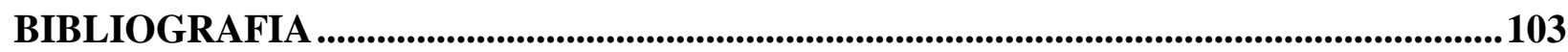




\section{AGRADECIMENTOS}

Não tenho palavras para expressar a gratidão que tenho com o Prof. Dr. Maurício Keinert, meu orientador, pela generosidade intelectual, pelo incentivo, pela tranquilidade na orientação e por ter sido o responsável pela abertura tantas oportunidades que qualquer aluno recém-graduado jamais cogitaria em ter em tão pouco tempo.

Agradeço particularmente à Profa. Dra. Monique Hulshof, presença constante em minha vida acadêmica desde a graduação e a cujas aulas devo a instigação de aprofundar os estudos em Kant. Também as muitas conversas enriquecedoras nos corredores, nos cafezinhos entre os estudos na biblioteca e nas reuniões do grupo de pesquisa.

Agradeço também à Profa. Dra. Maria Lúcia Mello e Oliveira Cacciola e ao Prof. Dr. Bruno Nadai pelas valiosas sugestões no extenso e prazeroso exame de qualificação, bem como por aceitarem compor agora a banca de defesa.

Devo agradecer também a pessoas que me ajudaram pontualmente ao longo de todo o mestrado: o Prof. Dr. Ricardo Terra, pelo acolhimento em seu grupo, em suas aulas na pósgraduação e pelas generosas sugestões bibliográficas todas incorporadas neste trabalho; aos Profs. Drs. Fernando Costa Mattos, Marisa Lopes, Rúrion Melo e Yara Frateschi pela acolhida no FICEM; e às meninas da secretaria do Departamento de Filosofia (especialmente à Marie Pedroso, Maria Helena, Luciana e Geni) pela simpatia desde o primeiro contato.

Por fim, agradeço à FAPESP: um empreendimento, tal como uma pós-graduação stricto sensu, para ser bem-sucedido depende de um concurso de fatores; um desses fatores, o apoio financeiro proporcionado, resultou na tranquilidade de dedicar-se integralmente aos estudos e na possibilidade de aproveitar as diversas oportunidades de viagens para troca de experiências e contatos acadêmicos em congressos brasileiros e internacionais. 


\section{RESUMO}

O que se pretende nesta pesquisa é buscar os procedimentos e pressupostos que conferem legitimidade à lei jurídica dentro da perspectiva da política kantiana. A pesquisa seguirá por três caminhos de investigação: primeiramente, a partir do artigo À paz perpétua e da Metafísica dos Costumes se busca lançar as bases do problema retomando a argumentação acerca da origem do Estado. Pela análise dos mecanismos e razões que conduziram à formação do Estado, perpassa-se por questões centrais da política kantiana como o estado de natureza, o contrato originário, a organização jurídica do estado civil e o republicanismo. Em um segundo momento, um passo inicial é incitar o debate sobre a fundamentação do direito ser externa ou interna, isto é, se a própria norma jurídica é suficiente para fundamentar a si mesma ou se necessita de um embasamento externo. Recorre-se à Fundamentação da metafísica dos costumes a fím de resgatar dali os conceitos de autonomia da vontade, o procedimento de universalização da máxima e o imperativo categórico a fim de estabelecer como se legitima a lei moral. Enfim, a última etapa argumentativa pretende efetivamente explorar se há um conflito e como resolvê-lo no que tange à conciliação entre o direito e a ética: como harmonizar a lei legítima fruto do republicanismo (advinda de uma representatividade) à lei que concorda com a autonomia da vontade.

Palavras-chave: Autonomia; Legitimidade; Republicanismo; Direito; Política 


\begin{abstract}
This study aims to seek the mechanisms and conditions that legitimise the legal law on the scope of kantian politics. This research will be divided in three argumentative moments. The first one is related to groundworking the problem by proceeding the arguments of "Toward Perpetual Peace" and "Metaphysics of Morals" about the origins of the State. Through the analysis of the mechanisms and reasons that guide to the State formation we aim to point some central questions on the kantian politics as the state of nature, the original contract, the juridical civil organisation of the state and the republicanism. The second argumentative moment, our first step is to promote the debate about the foundation of Law being internal or external. So we use the "Groundwork of Metaphysic of Morals" to rescue the concepts of autonomy of will, categorical imperative and the universalisation of maxim in order to expose how the moral law finds its legitimacy as well as if this procedure serves as example to be followed to legitimise the legal law. Finally, the last moment of this study is dedicated to think if there is a conflict between Law and ethics and how to solve it - how to articulate the legitimacy of the republicanism law (that comes from a political representation) to the law that comes from the autonomy of will.
\end{abstract}




\section{NOTAS SOBRE AS CITAÇÕES E ABREVIATURAS}

Os textos do filósofo têm por base a organização dada pela Academia (Akademieausgabe von Immanuel Kants Gesammelten Werk, 29 vols. Berlin: Walter de Gruyter, 2005). Para fins de referência durante o texto e nas notas de rodapé, utilizar-me-ei do sistema e das abreviações propostos pela Academia conforme descrição abaixo:

- À paz perpétua como ZeF seguido da indicação do volume (VIII) e o número da página;

- Antropologia de um ponto de vista pragmático como Anth seguido da indicação do volume (VII) e o número da página;

- Crítica da Razão Pura como $K r V$ seguido da indicação B (segunda edição revisada de 1781) e o número da página;

- Crítica da Razão Prática como $K p V$ seguido da indicação do volume (V) e o número da página;

- Crítica da Faculdade de Julgar como $K U$ seguido da indicação do volume (V) e o número da página;

- Fundamentação da Metafísica dos Costumes como GMS seguido da indicação do volume (IV) e o número da página;

- Ideia de uma história universal de um ponto de vista cosmopolita como IaG seguido da indicação do volume (VIII) e o número da página;

- Sobre a expressão corrente: isto pode ser correto na teoria, mas nada vale na prática como T.P. seguido da indicação do volume (VIII) e o número da página;

- Metafísica dos Costumes como MS seguido da indicação do volume (VI) e o número da página;

- Resposta à questão: que é o Esclarecimento? como WA seguido da indicação do volume (VIII) e o número da página;

- Sobre um suposto direito de mentir por amor à humanidade como VRML seguido da indicação do volume (VIII) e o número da página. 


\section{INTRODUÇÃO}

O presente trabalho busca investigar a justificação da lei jurídica no horizonte da política kantiana, isto é, reconhecer como se dá a legitimação da lei jurídica no contexto teórico preciso do republicanismo: "a constituição política de cada Estado deve ser republicana”, enuncia Kant no primeiro artigo definitivo do tratado À paz perpétua (ZeF, AA VIII:349). Dentre as maneiras de se organizar as formas constitucionais dos Estados, Kant afirma ser possível adotar dois eixos distintos para análise: segundo o modo como o chefe de governo exerce o poder (forma de governo) ou segundo as pessoas que detêm o poder supremo (forma de soberania); o republicanismo, esclarece-nos ele, é justamente uma das duas formas de governo possíveis: quando o poder executivo é distinto do poder legislativo, em contraposição ao despotismo, isto é, quando não se vislumbra a separação de poderes - a essas formas de constituição se mesclam as formas de soberania, que são três: autocrática, se a soberania é exercida por um só; aristocrática, se exercem a soberania somente alguns; ou democrática, se todos juntos perfazem o poder soberano ${ }^{1}$. É possível, portanto, um gradiente de formas constitucionais: um Estado autocrático pode ser republicanamente orientado sem constituir-se, de fato, em uma república ${ }^{2}$. O elemento distintivo do republicanismo é, portanto, a representatividade — ao mesmo tempo é também uma condição sine qua non: “toda forma de governo que não é representativa é propriamente uma nãoforma, porque o legislador não pode ser em uma mesma pessoa ao mesmo tempo executor de sua vontade" (ZeF, AA VIII:352).

Um paralelo com a ética e o princípio de autonomia da vontade é inevitável. Tal necessidade de se falar em autonomia para tratar da lei jurídica tem uma face curiosa no caso específico de Kant: tradicionalmente, a noção de autonomia é vinculada ao pensamento político e tem suas raízes na autonomia das cidades-estados gregas; contudo, podemos entender que é com e a partir de Kant que o uso do termo autonomia se aplica diretamente à capacidade do agir individual $^{3}$ — noutras palavras, a noção de autonomia é moralizada para o sujeito agente por Kant

\footnotetext{
${ }^{1}$ Cf. ZeF, AA VIII:351-353.

${ }^{2}$ É o caso de se reconhecer uma tênue distinção entre a república e republicanismo: a república é propriamente a ideia da constituição política perfeita $(\mathrm{KrV}, \mathrm{B} 373)$; o republicanismo, por sua vez, é quando a orientação republicana é adotada in abstrato porém não in concreto. Cf. NOUR, Soraya. À paz perpétua de Kant: filosofia do direito internacional e das relações internacionais. São Paulo: Martins Fontes, 2004, p. 44.

${ }^{3}$ Cf. O’NEILL, Onora. Bounds of Justice. New York: Cambridge University Press, 2000, pp. 40-41. O’Neill, por sua vez, trabalha a partir de uma distinção bem estabelecida por Scheewind: distinguir "autogoverno" de "autonomia" (cf. SCHNEEWIND, Jerome B. The invention of autonomy. New York: Cambridge University Press, 1998, pp.513515). A filiação de O’Neill a essa tese e seu alargamento em direção a "pensar que a autonomia no sentido que Kant atribui ao termo é decerto tanto uma concepção de razão prática como também fundamental para a moralidade" pode ser conferida em O'NEILL, Onora. “Autonomia, pluralidade e razão pública”. In: Cadernos de Filosofia Alemã. São Paulo: FFLCH-USP, v. 19, n. 1, jan-jun. 2014, pp. 15-34. A tese de Schneewind é que a moralidade como autonomia é uma das expressões de moralidade como autogoverno e, nesse sentido, pode ser compreendida propriamente uma
} 
ao torná-la princípio constitutivo e imanente da vontade humana. A face curiosa fica por conta de que nesta investigação pretende-se justamente perscrutar a ética kantiana a fim de saber se é possível estabelecer algum paralelo entre o princípio de autonomia da vontade e a autonomia jurídico-política: a unidade de medida que consideramos boa e, portanto, o ponto seguro de partida para procurar uma boa constituição para o campo da política é justamente fruto de uma inversão própria do autor frente à tradição. A questão da legitimidade, em Kant, se aclara na medida que demonstramos o que é a autonomia ${ }^{4}$.

Há um tipo de lei que incontestavelmente goza de insuspeita segurança quanto à sua fundamentação e esta é a lei moral. A segurança dessa lei, no tocante da questão da sua legitimidade, baseia-se no fato que ela obriga categoricamente ao mesmo tempo em que não é ditada por nem espelhada em uma racionalidade externa (como via de regra foi o caso da tradição — ou a autoridade da lei repousava no sábio, ou na autoridade divina ou na força de outrem mais forte $^{5}$ ): então de onde decorre seu caráter obrigante? Ora, decorre da sua gênese mesma: a lei moral

invenção kantiana. Outros autores, justifica ele, trabalharam com uma noção de autonomia que, baseado no fato de que nessas concepções restava sempre a dependência da teoria a um vínculo ou intermediação de algum elemento externo que ditava as medidas da moralidade, não alcançavam a autonomia em sua forma plena posto que dependente de autoridade externa. Restava sempre uma dependência naturalista ou uma dependência divina como a fonte da moralidade (fosse voluntarista ou intelectualista); senão, como nas noções modernas mais bem-acabadas de Hume e Rousseau, repousava-se em noções de um sentimento moral ou da autonomia como efeito da participação em algum tipo especial de sociedade. Nesse sentido, afirma que a "a autonomia kantiana pressupõe que sejamos agentes racionais cuja liberdade transcendental tire-nos do domínio da causação natural. Pertence a cada indivíduo, seja no estado de natureza ou bem em sociedade", de maneira que "porque está ancorada na liberdade transcendental, jamais a perderemos" porque capacidade própria da humanidade mesma.

${ }^{4}$ A questão da autonomia diz respeito a toda a razão, sendo a figura mais emblemática no âmbito da filosofia crítica aquela do tribunal da razão como símbolo da empresa crítica. A figura do tribunal da crítica nos guia, novamente, à alegada origem política do termo "autonomia" e à conclusão que com a questão da autonomia se liga indelevelmente a questão da autoridade. A pergunta que fica em suspenso e que, apesar de não dizer respeito ao escopo estrito desta investigação, merece ser posta é a seguinte: até que ponto se pode compreender o status de "inversão" quando falamos em apropriação pela moral de uma noção historicamente política? Houve mesmo uma inversão ou seria o caso de reconhecer que todo o empreendimento crítico tem um interesse iminentemente político desde seu verdadeiro início? A favor dessa tese, são muito felizes os trabalhos que chamam a atenção para as metáforas político-jurídicas presentes em toda a obra crítica (cf. os trabalhos de SANTOS, Leonel Ribeiro. Metáforas da razão. Lisboa: Fundação Calouste Gulbenkian, 1994, pp. 561-632; SANTOS, Leonel Ribeiro. "Da linguagem jurídica da filosofia crítica à arqueologia da razão prática”. In: SANTOS, Leonel Ribeiro; ANDRÉ, José Gomes. Filosofia kantiana do direito e da política: seminário internacional. Lisboa: Universidade de Lisboa, 2007, pp.205-223; O’NEIL. Constructions of reason. Cambridge: Cambridge University Press, 1989, pp. 3-50; TREVISAN, Diego. "O problema da linguagem no discurso filosófico kantiano como questão político-jurídica”. In: Cadernos de Filosofia Alemã. São Paulo: FFLCH-USP, ${ }^{\circ}$ 20, jul-dez. 2012, pp. 81-100).

${ }^{5}$ Sobre esse ponto, é interessante notar desde já um apontamento de Kant que será muito caro para nossa investigação: ao tratar, no segundo artigo definitivo d'À paz perpétua, sobre a situação de guerra entre os Estados e estabelecer que o estado de natureza ocorre entre indivíduos bem como Estados constituídos se estes não estabeleceram entre si uma ordem jurídica, isto é, um direito internacional cuja forma perfeita fosse um federalismo, o filósofo faz a constatação de que o interesse na ideia de direito é um signo de uma boa disposição no homem. Noutras obras (especialmente o primeiro capítulo d'A religião nos limites da simples razão) está presente a noção de uma natureza humana essencialmente má; já n’À paz perpétua essa ideia se fazia presente: "pela maldade da natureza humana, que se faz ver descoberta na relação livre dos povos (ao passo que se dissimula muito no estado civil e legal pela coerção do governo), é de se admirar que a palavra direito ainda não tenha sido inteiramente relegada em política de guerra como pedante, e ainda nenhum Estado tenha-se atrevido a declarar-se publicamente pela última opinião" (ZeF, AA VIII:355). Contudo, ele continua, há de se notar que em matéria de guerra os Estados continuavam a invocar juristas como Grotius ou Pufendorf a fim de legitimarem suas intenções no solo do direito. Ora, "essa homenagem que cada 
nada mais é que o reconhecimento por cada vontade humana que seu princípio de ação tem caráter universal inequívoco, isto é, de cada vontade poder se ver como legislando a própria lei e que, ao mesmo tempo que se vê como autora da lei, é também subordinada a ela por seu próprio querer. Se considerarmos que o princípio de autonomia de um ser pode ser compreendido como a propriedade de "uma vontade que legisla universalmente através de todas as suas máximas" (GMS, IV:432) de tal sorte que, utilizando-se do linguajar político da Fundamentação da Metafísica dos Costumes, essa vontade é ao mesmo tempo legisladora e súdita da legislação que ela mesmo cria, então a pergunta fundamental desta investigação pode ser recolada diretamente à luz dos novos termos: em um ambiente republicano e, portanto, necessariamente representativo como pode ser legítima a lei jurídica para Kant? Pois na ética, isto é, nas questões da virtude, não há nada entre a vontade e a atividade legislativa mesma; contudo, no campo jurídico-político, há um "princípio intermediário"6 na equação da autonomia - a representatividade. O problema que se esboça é este: o cidadão tem de acatar as leis positivas, mas há algum componente autônomo na obediência ao direito instituído? Quais seriam as possibilidades que permitiriam não apenas ao indivíduo, mas também aos cidadãos agirem autonomamente?

O fundamento mais básico da autonomia é um único: o princípio supremo da moral. E expressa-se à maneira canônica da primeira formulação do imperativo categórico, de acordo com a Fundamentação da Metafísica dos Costumes, “age apenas segundo a máxima pela qual possas ao mesmo tempo querer que ela se torne uma lei universal" (GMS, AA IV:421) ou, em sua forma final dada na Introdução da Metafísica dos Costumes, "aja conforme a uma máxima que possa valer ao mesmo tempo como uma lei universal" (MS, AA VI:225). De fato, Kant afirma que o imperativo categórico é um só e que as diversas formulações nada mais são do que o mesmo princípio expresso de outras maneiras. É lícito concluir, portanto, que o princípio de autonomia é um só porque ancorado no imperativo categórico - que é um único. Contudo, segundo cada campo do saber que se forma de acordo o ponto de vista que se toma a liberdade, não seria o caso de se dizer que há diferentes expressões de autonomia? Sendo essa hipótese razoável, deveríamos conceder também que há diferentes formas de mensurar a legitimidade da lei de acordo com cada campo.

Estado presta ao conceito de direito (pelo menos segundo as palavras) demonstra, contudo, que se encontra no homem uma disposição originária maior" (ZeF, AA VIII:355 - grifo nosso): qual seria essa disposição originária maior? Aquela vontade de ser senhor do princípio mau encerrado em sua natureza e, de maneira justa, esperar a mesma disposição dos outros. O signo dessa disposição é o conceito de direito - isso nos dá pistas sobre o tipo específico de teoria do direito que Kant irá propor e que aclararemos no decorrer de nossa exposição.

${ }^{6}$ VRML, VIII:427. 
A questão fundamental desta investigação tem sua chama inicial a partir do conceito de Estado. Em Kant, o problema do estabelecimento do Estado é tratado em termos originais n'À paz perpétua:

O problema do estabelecimento do Estado, tão duro como isso soe, pode ser solucionado mesmo no caso de um povo de demônios (se somente eles tiverem entendimento) e exprime-se assim: 'ordenar uma multidão de seres racionais, que no todo exigem leis universais para sua conservação, das quais, porém, cada um está inclinado a eximir-se em segredo, e estabelecer sua constituição de modo que, embora tentem uns contra os outros em suas disposições privadas, as contenham uns aos outros de modo que o resultado em sua conduta pública seja justamente o mesmo como se não tivessem nenhuma das tais más disposições'. Pois não é o aperfeiçoamento moral dos homens, mas somente o mecanismo da natureza, do qual é exigida a tarefa de conhecer como se pode utilizá-lo nos homens para dirigir de modo tal o conflito das disposições hostis num povo que eles mesmos forcem uns aos outros a submeter-se a leis de coerção e assim tenham de conduzir ao estado de paz, no qual as leis têm força" (ZeF, VIII:366)

Há alguns blocos de questões que concorrem entre si para ser possível abarcar toda a problemática que esta pesquisa pretende debruçar-se e em vista disso a presente dissertação apresenta-se em três capítulos. Uma maneira de compreender a razão da divisão a que procedemos é pelo ponto de vista da questão mais premente de ser perseguida: como afirmamos há pouco, avançar na exposição da autonomia nos guia infalivelmente em direção ao reconhecimento da legitimidade da lei e esse avanço se faz aqui com gradações que têm por finalidade adentrar na filosofia kantiana respeitando as tensões originais (sem intenção de solvê-las arbitrariamente). No pensamento kantiano faz-se presente sempre algum tipo de tensão; duas delas são particularmente tangenciadas e por vezes exploradas nesta dissertação: primordialmente, a todo momento se faz presente uma tensão entre indivíduo e espécie - pela perspectiva da moral exclusivamente teórica (ética e direito) a ação individual aparece como elemento de maior relevo mesmo quando pensada socialmente; pela perspectiva da filosofia política e da filosofia da história, ganha corpo o enfoque na espécie e na ideia de um progresso acumulado do gênero humano passado e aumentado geração em geração. Decorrente dessa primeira tensão, entre a filosofia do direito e as filosofias da política e da história, há uma tensão entre elementos liberais e elementos republicanos em seu pensamento. Nossa interpretação aqui é a seguinte: o filósofo mantém a tensão entre uma concepção jurídica preferencialmente liberal e uma concepção político-histórica, mais abrangente, preferencialmente republicana; a concepção de autonomia em sua expressão política, tal como lidamos aqui, requer bases republicanas ${ }^{7}$.

\footnotetext{
${ }^{7}$ O terceiro capítulo desta dissertação trabalha sobre a noção de que é possível o progresso de uma sociedade por si mesma no curso da história, isto é, que a possibilidade que a política kantiana desvela é afirmar seguramente a possibilidade de autodeterminação de uma sociedade. Essa autodeterminação é uma expressão de autonomia em seu caráter político - a questão que se põe nesse terceiro capítulo é: “como essa autodeterminação é possível?”. A ideia de autodeterminação da sociedade só se pode tornar efetiva se pensarmos um processo pelo qual os cidadãos tomam conhecimento de si mesmos enquanto sociedade e, assim, habilitam-se a modificar no curso da história sua própria identidade. Os elementos liberais do pensamento kantiano devem ser tomados como garantidores das condições
} 
Se o direito político se mostra a via preferida para analisar a questão do estabelecimento do Estado, é necessário proceder anteriormente a algumas aclarações sobre as bases do direito em Kant e a diferenciação entre direito e política tomando por base a relação entre a doutrina teórica e a doutrina prática - especialmente aquela doutrina cujo objeto é o dever. Muito tem-se escrito na literatura kantiana sobre especificidades próprias da filosofia política e da filosofia da história kantianas; em Kant, ambos os campos trazem uma dupla novidade ao inaugurar tanto uma nova maneira de enxergar o próprio papel desses campos do saber quanto um conteúdo novo de reflexão. Questões da filosofia da história surgem nos três capítulos seguintes. Primeiramente, deve ser demonstrada a relação entre a filosofia moral e a filosofia da história enquanto estruturas maiores: qual o papel que cabe e a especificidade de cada campo do saber dentro do sistema completo - a filosofia da história surge assim como o fator de coesão do campo prático na medida que lida com fins. Em um segundo momento, quando do estudo específico das ideias políticas e, portanto, fazendo uma leitura bastante próxima do tratado d’À paz perpétua, a filosofia da história novamente surge no horizonte da reflexão: desta vez, insere-se na discussão trazendo "garantias" para o progresso institucional proposto no projeto político ao tirar o foco do sujeito e lançar luzes ao todo da espécie. Por fim, no terceiro capítulo trata-se especificamente de um tópico retirado da reflexão sobre a história - a questão do progresso e, mais especificamente, como realizar o progresso moral.

À luz das formulações do princípio transcendental do direito público, apresenta-se o locus onde se dá a autonomia em sua expressão política: no uso público da razão — a máxima necessita poder ser confessada publicamente para saber se a pretensão que porta consigo é justa ou injusta.

O esforço que se fará nas páginas seguintes é um esforço de compor um mosaico: segmento do texto que ora se apresenta é como um pedaço que se esforça em articular-se aos outros pedaços autônomos a fim de construir uma forma completa. O que faremos, de um capítulo a outro, são passagens no sentido kantiano estabelecido do termo: sem desconsiderar o ponto de vista próprio de cada campo do saber, passamos à análise das mesmas questões sob os pontos de vista distintos da filosofia moral, da filosofia política e da filosofia da história mantendo as tensões próprias da articulação das partes com o todo do sistema e seu inter-relacionamento. A figura final desse esforço nos permitirá concluir se é lícito falar em uma expressão política da autonomia e se esse

mínimas necessárias para a efetividade dos elementos republicanos, isto é, tomamos o trecho em que Kant afirma que "a verdadeira política não pode, pois, dar um passo sem antes prestar homenagem à moral” (ZeF, AA VIII:380) literalmente afirmando que a doutrina do direito é necessariamente anterior à política: só se pode pensar em ganhos republicanos quando a estrutura mínima liberal (o direito público garantido por instituições públicas) está posto. Alguns autores seguem interpretação diferente; acerca desse assunto, cf. POGGE, Thomas. "Is Kant's Rechtslehre a 'comprehensive liberalism'?”. In: TIMMONS, Mark (org.) Kant's Metaphysics of Morals: interpretative essays. Oxford: Oxford University Press, 2002, pp. 133-158; TRENTANI, Federica. "A política como realização do projeto da razão prática". In: Studia Kantiana, nº 16, 2004, pp. 91-104. 
tipo de autonomia é merecedor do mesmo status seguro que gozam a autonomia ética e a autonomia jurídica relativamente à teoria. 


\section{I - MORALIDADE: RELAÇÕES ENTRE ÉTICA, DIREITO E POLÍTICA}

No presente capítulo pretende-se explorar o terreno amplo sobre o qual se assenta esta investigação: a moral kantiana e suas inter-relações. Para seguir nesse intento, tomamos centralmente por base as seguintes obras a fim de estabelecer os fundamentos e o sistema da moralidade: a Fundamentação da Metafísica dos Costumes (1786) e a própria Metafísica dos Costumes (1797). O objetivo que nos propomos neste segmento específico da argumentação é, como já mencionado anteriormente, adentrar no sistema moral kantiano de maneira que reconheçamos a autonomia em suas expressões características segundo cada um dos campos do saber que compõem a moralidade - ética, direito e política.

Tratar da moralidade, no âmbito da filosofia kantiana, requer que nos detenhamos em algumas aclarações conceituais. Como primeiro ponto, devemos reconhecer que há uma polissemia no uso do termo moral: algumas vezes é utilizado em um sentido estrito (referindo-se à ação praticamente necessária) e noutras vezes aponta para um sentido mais amplo ${ }^{8}$. O que nos interessa aqui é a moral em sentido amplo: a articulação entre o par formado pela ética e pelo direito - campos da liberdade interna e liberdade externa (do ponto de vista da legislação da liberdade) ou dos deveres da virtude e dos deveres jurídicos (do ponto de vista do modo de obrigação). A moral em seu sentido amplo é o mesmo objeto que aponta a expressão "doutrina universal dos costumes", nos termos da Metafísica dos Costumes, sendo essa a razão pela qual utilizaremos os termos de maneira inteiramente intercambiável. Kant distingue duas maneiras de efetuar a divisão da doutrina universal dos costumes: através da análise centrada no conceito de dever ou senão da análise centrada no conceito de fim"; contudo, há uma terceira divisão tradicional tal como supramencionada - segundo o ponto de vista das legislações da liberdade. As expressões de autonomia que surgem no interior de cada uma dessas divisões são a autonomia ética e a autonomia jurídica.

Prosseguindo no mapeamento do campo da moral, o campo do direito pode ser dividido também em duas doutrinas: enquanto uma doutrina teórica e enquanto uma doutrina prática. O que Kant compreende como "doutrina prática ${ }^{10}$ do direito" é senão a política:

\footnotetext{
${ }^{8}$ TERRA, Ricardo. Kant e o direito. Rio de Janeiro: Jorge Zahar Editor, 2004, p. 13-14.

${ }^{9}$ Cf. MS, AA VI:381.

${ }^{10}$ Há uma escolha interpretativa na maneira como traduzimos a expressão «als ausübender Rechtslehre» como "doutrina prática do direito". Ricardo Terra (Passagens: estudos sobre a filosofia de Kant. Rio de Janeiro: Editora da UFRJ, 2003, p. 91) utiliza-se por vezes da forma "doutrina executiva do direito" em seus estudos, Marco Zingano traduz a expressão do alemão como "doutrina aplicada do direito" e Artur Morão grafa como "teoria do direito aplicado". O verbo ausüben pode ser traduzido como "exercer" ou "praticar", portanto acredito tornar-se mais intuitivo referir-se à política como doutrina prática do direito para, inclusive, manter coesão em torno de um mesmo campo semântico entre os trabalhos de Kant (tenho em mente o escrito kantiano Sobre a expressão corrente: isto pode ser correto na teoria, mas nada vale na prática).
} 
Não pode haver nenhum conflito da política, como doutrina aplicada do direito «als ausübender Rechtslehre», com a moral, como doutrina do direito, mas teórica (por conseguinte, nenhum conflito da prática com a teoria) (ZeF, AA VIII:370).

O sentido da política ser a doutrina prática do direito deve ser cuidadosamente verificado para afastar a concepção que a política é a mera execução direta e instantânea dos princípios preconizados pela doutrina do direito teórica. Uma interpretação nesse sentido tem de ser rechaçada firmemente como errônea, pois revela desconhecimento tanto do papel e da natureza do Direito e da prática (em sentido kantiano estrito) no sistema.

Nestes parágrafos iniciais foram apontadas definições aparentemente conflitantes: primeiramente apresentou-se a moralidade como um campo tripartite (ética/direito/política), para então ser caracterizada em seguida como um campo bipartite (ética e direito). Subjaz a essas divisões a noção que cada um desses campos tem uma expressão de autonomia própria - então por que ainda não se falou de uma autonomia política? Esse problema tem a ver com o status e o lugar da política no sistema kantiano; justamente a primeira seção deste capítulo debruçar-se-á sobre as condições preliminares que temos de levar em conta para analisar a natureza de uma prática para objetos que só se representam mediante conceitos (como é o caso da moralidade). A política, como parte prática do direito, deve fazer parte da moral se tiver status ontológico próprio (e tem $)^{11}$; contudo, a política que não atende às condições necessárias para ser prática não faz parte da moral e, portanto, seria melhor que nos referíssemos a essa política como práticas políticas apartadas de sua teoria mater (a moral) — alhures, nesta investigação ${ }^{12}$, se confirmará essa diferenciação entre dois tipos de acepção da política.

Uma vez que tenha sido alcançada a importante distinção entre a teoria e a prática, em sentido kantiano, a continuação de nossa investigação será dedicada a retomar os principais elementos constituintes de cada uma das partes teóricas do sistema moral: seguimos fiéis à afirmação anteriormente sustentada de que expor a autonomia e suas expressões é a forma mais segura de se alcançar a questão da legitimidade das leis (sejam éticas ou jurídicas). Compreendemos que a filosofia moral de Kant está exposta largamente na Fundamentação da

\footnotetext{
${ }^{11}$ A expressão "status ontológico próprio" deve ser lida com cautela: o status que se refere aqui é diferentemente do tratado na Introdução a esta dissertação (nota 7 - na qual Pogge defende uma independência da política frente à teoria moral kantiana). Trata-se aqui do comentário de Hassner: “em certo sentido, não há uma filosofia política kantiana estritamente falando; há consequências políticas de uma filosofia jurídica fundada sobre uma filosofia moral e garantidas por uma filosofia da história" (cf. HASSNER, Pierre. "Situation de la philosophie politique chez Kant". In: WEIL, Eric. (org.) Annales de philosophie politique no 4: la philosophie politique de Kant. Paris: Presses Universitaires de France, 1962, p. 101). Nossa posição concorda com Hassner na medida que reconhece uma dependência do direito à moral e a garantia da realização do direito pela filosofia história, contudo discordamos quanto ao status da filosofia política como meros efeitos de uma filosofia jurídica - a filosofia política tem, nesse sentido, um status ontológico próprio no sistema kantiano como doutrina prática.

${ }^{12}$ No capítulo terceiro se desenvolve a tese que há máximas típicas das práticas políticas que devem ser submetidas a um procedimento análogo ao imperativo categórico para saber se são justas ou injustas; se foram justas, essas máximas políticas harmonizam-se com a moral e assim se forma o repertório material de uma política-moral.
} 
Metafísica dos Costumes, contudo utilizamos aqui para estruturar nossa argumentação o caminho apontado pela Metafísica dos Costumes: a exposição daqueles que são os elementos mínimos para qualquer teoria moral racional; esses elementos mínimos têm seu lugar na Introdução geral e comum a toda a Metafísica dos Costumes, na seção "Conceitos preliminares da Metafísica dos Costumes" ou "Philosophia practica universalis".

Se ética e direito são campos contíguos do interior de uma mesma teoria, a saber, a doutrina universal dos costumes, é justa a expectativa de que estejam sob o império de um mesmo princípio:

O princípio supremo da doutrina dos costumes é, portanto: aja segundo uma máxima que possa valer ao mesmo tempo como lei universal. Cada máxima que não se qualifica a isso é contrária à moral. (MS, AA VI:226)

Noutras palavras, o imperativo categórico é o princípio supremo que mantém a coesão sistemática tanto para os deveres jurídicos quanto para os deveres da virtude. Contudo, há um problema de omissão: Kant em nenhum momento diz como se coordena essa coesão, isto é, como se dá a subordinação tanto do direito quanto da ética sob o imperativo categórico. Tal omissão é o suficiente para que alguns intérpretes questionem a natureza do direito no interior da filosofia kantiana: havemo-nos neste tocante com o questionamento da fundamentação do direito - se o direito é dependente externamente de uma moralidade ou se constitui uma disciplina apartada e meramente reportada à moral de maneira não vinculante. Então, caberá a esta investigação debruçar-se em algum momento sobre essas teses da justificação interna e independente do direito a partir de dois estudos de caso: a teoria pura do direito (de Hans Kelsen) e a tese da independência do direito (abordada a partir de Wood e Willaschek). A escolha desses dois casos se justifica na medida que ambas as teorias se reportam inegavelmente ao pensamento kantiano e ambas resultam no mesmo efeito por caminhos diferentes, a saber, afastar a justificação do direito do campo moral - a teoria pura pela via da refutação de valores estranhos à validade do direito e a tese da independência do direito frente a moral no interior da filosofia prática kantiana pelo argumento de que os deveres jurídicos não se derivam do imperativo categórico.

Para findar as reflexões deste capítulo, abordaremos questões de ordem sobre o status da política e da filosofia da história e seus inter-relacionamentos dentro do sistema prático: ambos os campos têm uma orientação à coesão arquitetônica do sistema. São, portanto, elementos privilegiados que promovem algum tipo de coesão na medida em que apontam para o todo da espécie; método oposto ao direito e à ética, que focalizam o sujeito (ainda que um sujeito inserido em uma pluralidade). 


\subsection{Considerações estruturantes}

Esta primeira seção é dedicada a duas considerações para se adentrar no sistema moral kantiano, que julgamos necessárias abordar: em um primeiro momento, a questão da metafísica por abranger todo o sistema; em seguida, em qual sentido se deve compreender o que é a teoria «Theorie» e o que é a prática «Praxis». A seara desta investigação é o campo da política, sendo que a filosofia política kantiana deve ser encarada como uma metafísica de caráter prático.

É preciso, portanto, remarcar o caráter metafísico inerente à doutrina dos costumes e por que não afirmá-lo? - inerente mesmo a todo o campo prático do pensamento político kantiano ${ }^{13}$. Assim, a pergunta a se fazer é: o que se compreende exatamente por "metafísica" quando falamos da moral em sentido amplo? Não há um único sentido de metafísica em Kant, assim como também não houve um único sentido de metafísica para a tradição filosófica. Não poucos comentadores chamam a atenção para o fato de se haver centrado o foco da ribalta, durante muito tempo, ao núcleo duro da filosofia crítica (sob o viés especialmente da Crítica da Razão Pura): não é o caso de que com isso se pretende sugerir aqui que suas demais obras foram relegadas ao esquecimento, pois olhar para a história da recepção do pensamento kantiano é o suficiente para dar ciência do esforço de uma longa tradição no debate e revitalização de seu pensamento. O que se chama a atenção aqui é, justamente, para se ter em mente as diferentes recepções e os efeitos díspares que se formaram a partir das inúmeras apropriações ${ }^{14}$. Assim desfazem-se mitos populares acerca da filosofia crítica kantiana e sua relação com a metafísica. Acentuar preliminarmente o caráter metafísico da filosofia prática kantiana serve para aclarar a natureza do chão sobre o qual esta investigação se erige (a moralidade) e possibilita chamar a atenção para diferenças sutis, tal qual de que existem sentidos de metafísica em Kant, e tornar claro que, certamente, o sentido que formava o problema central na Crítica da Razão Pura não é o mesmo que aquele em uso na Metafísica dos Costumes. Relativo ao sistema dos costumes, uma metafísica em sentido crítico é, por sua natureza mesma, uma teoria pura que se erija a partir de proposições a priori ao mesmo tempo que lida com elementos empíricos mínimos (e por isso pode ser dito que oferece uma passagem entre a teoria em sua pureza à sua consecução). Veremos que uma

\footnotetext{
13 Há posições controversas sobre o tema. A filosofia política e a filosofia da história, em Cassirer, são indubitavelmente descritos como metafísicos: os textos políticos e os textos sobre história são intimamente conectados em sua análise (cf. CASSIRER, E. Kant's life and thought. New Haven: Yale University Press, 1981, pp. 218-231). Por outro lado, como já abordamos e veremos adiante com mais vagar em momento apropriado, Hassner defende a posição que a não há propriamente uma filosofia política em Kant, mas, estritamente, consequências políticas que são efeito de uma filosofia jurídica — a política não teria um estatuto próprio.

${ }^{14}$ Uma dessas apropriações tem como centro de gravidade o trabalho da Crítica da Razão Pura, que é contemporânea ao próprio Kant e pode ser verificada em cartas, indicava no sentido que o empreendimento crítico tivesse devorado o próprio projeto que o suscitara - a metafísica; cf. LEBRUN, Gerard. Kant e o fim da metafísica. São Paulo: Martins Fontes, 2002, p. 394.
} 
metafísica assim é possível e, inclusive, uma contraparte necessária àquela teoria que lida com elementos empíricos no sistema do conhecimento.

Também já se definiu a política como a "doutrina prática do direito". Com essa definição introdutória se colocou um problema específico de grande monta: por trás desses termos, que carregam uma generalidade em si mesmos, o que precisamente se quer dizer com essa expressão? Sugere-se que a política é meramente a aplicação ou meramente a execução imediata dos princípios expressos na Doutrina do Direito? Certamente que não. Pretende-se trazer à tona a diferença entre a teoria e a prática apoiando-nos na introdução do opúsculo "Sobre a expressão corrente: isto pode ser correto na teoria, mas nada vale na prática” (TP, VIII:275-278), pois ali há um valoroso esclarecimento do filósofo sobre a questão. Entendemos que a política "enquanto doutrina prática do direito" deve ser compreendida com esse sentido preciso de prática «Praxis»e que qualquer outra tentativa de acepção do termo não seria senão um desvio mesmo da prática.

\subsubsection{Moral como metafísica}

A moral é uma metafísica em Kant. O que se deve compreender por essa afirmação? O termo metafísica não tem um sentido unívoco em toda a obra kantiana ${ }^{15}$ : seria um erro grosseiro considerar a ideia prática da república como sendo de uma mesma natureza inalterada que as três grandes ideias da Crítica da Razão Pura. Lebrun ${ }^{16}$ afirma que a metafísica habilitada por Kant tem como único tema a relação com o suprassensível: é uma afirmação verdadeira, porém não de todo abrangente e em razão disso ora abordamos os sentidos de metafísica na obra kantiana.

Por sentidos de metafísica ${ }^{17}$ reconhecemos ao menos quatro tipos na obra kantiana: o primeiro deles é o de uma metaphysica generalis, ou seja, nada mais que a ontologia clássica. $\mathrm{O}$ segundo tipo é a metaphysica specialis, que investiga os objetos clássicos da metafísica tradicional e relaciona-se com as disciplinas da teologia natural (Deus), psicologia racional (alma) e cosmologia geral (mundo). O terceiro tipo é a metaphysica naturalis, que trata da disposição

\footnotetext{
${ }^{15}$ A maior parte dos autores consultados não faz a distinção entre os tipos de metafísica; todos, contudo, referem-se a um único sentido de metafísica e tal sentido corresponde ao sentido que aqui pretendemos apontar, isto é, de metafísica aplicada. O comentário de Allen Wood sintetiza a posição da maior parte dos comentadores: "Já no tempo da Crítica da Razão Pura, 'metafísica' (quando aplicada tanto para a natureza quanto para a moral) referia-se a um corpo de princípios sintéticos a priori e esse sentido governou o uso kantiano do termo na Fundamentação (1785). Nessa altura, Kant concebia uma 'metafísica dos costumes' como um sistema de princípios morais, mesmo de deveres morais, que poderia ser inteiramente a priori e, portanto, poderia ser construído de forma totalmente independente de qualquer conhecimento empírico da natureza humana" (cf. WOOD, Allen. "The final form of Kant's practical philosophy". In: TIMMONS, Mark. (org.) Kant's Metaphysics of Morals: interpretative essays. New York: Oxford University Press, 2004, p. 2).

${ }^{16}$ Cf. LEBRUN, op. cit., p. 50.

${ }^{17}$ Essa divisão corresponde à divisão procedida por Christian Wolff e à qual a filosofia alemã lidou classicamente. Cf. TREVISAN, 2011, p. 125-127; CAIMI, Mario. La Metafísica de Kant. Buenos Aires: UBA, 1989.
} 
natural do homem em tentar conhecer os objetos clássicos da metafísica tradicional no movimento de descolar-se em favor do suprassensível e conhecer assim os objetos da metafísica especial. O quarto tipo, de maior relevância para nossa investigação, é a metaphysica applicata: a disciplina que aplica proposições a priori relativamente a um dado elemento empírico mínimo. O esforço do empreendimento da Crítica da Razão Pura foi no sentido de negar o caráter científico ao suposto conhecimento alcançado pela metafísica geral e pela metafísica especial, mas em salvaguardar a metafísica aplicada como "legítima" - esse entendimento coaduna-se com a divisão do conhecimento racional retomada no Prefácio da Fundamentação da Metafísica dos Costumes:

Todo conhecimento racional é ou material, e considera um objeto qualquer, ou formal, e ocupa-se meramente da forma do entendimento ou da razão ela própria e das regras universais do pensamento em geral, sem distinção dos objetos. A filosofia formal chamase Lógica; a material, porém, que tem a ver com objetos determinados e com as leis a que estão submetidos, é, por sua vez, dúplice. Pois essas leis ou são leis da natureza ou são leis da liberdade. A ciência da primeira chama-se Física, a da outra é a Ética; àquela também dá-se o nome de Doutrina da Natureza; a esta, Doutrina dos Costumes (GMS, IV:387).

Com efeito, à metafísica aplicada pertencem tanto a Metafísica da Natureza quanto a Metafísica dos Costumes. Na sequência do mesmo prefácio, Kant procede a uma nova divisão da filosofia:

Pode-se chamar empírica a toda Filosofia na medida em que ela se estriba em razões empíricas, mas àquela que apresenta suas doutrinas unicamente a partir de princípios $a$ priori, Filosofia pura. A última, se ela é meramente formal, chama-se Lógica, mas se ela se restringe a objetos determinados do entendimento, então ela se chama Metafísica (GMS IV:388).

Kant defende que o conhecimento de verdades universais e necessárias deve ser dado a partir de juízos a priori puros, pois a experiência pode unicamente informar como as coisas são contingencialmente em uma dada circunstância, mas não como devem ser; destarte, à experiência pertencem os chamados juízos a posteriori ou, quando muito, juízos a priori híbridos ${ }^{18}$. O que se desvela aí é um mapa do sistema filosófico: cada campo do conhecimento que se dirige a objetos determinados se desdobra em uma parte pura (baseada em juízos sintéticos a priori) e em uma parte empírica (baseada em juízos sintéticos a posteriori); dessa maneira, o campo do saber cujo objeto é a natureza, tem sua parte pura em uma Metafísica da Natureza e sua parte empírica na Física; e a disciplina tradicional da Ética também se encontra nessa divisão, de maneira que sua

\footnotetext{
${ }^{18}$ Sobre os juízos a priori, Kant afirma que são aqueles que têm independência absoluta de qualquer experiência (KrV, B3). Acrescenta ainda que alguns desses juízos a priori são puros: "na terminologia kantiana, «puro» é aquilo que nada tem de empírico. Os juízos a priori puros, portanto, são aqueles que não envolvem sequer conceitos empíricos, ou seja, conceitos que formamos a partir da experiência" (cf. GALVÃO, Pedro. "Introdução". In: KANT, Immanuel. Fundamentação da Metafísica dos Costumes. Lisboa Edições 70, 2009, p. VIII). Os juízos a posteriori são também denominados empíricos porque se deve recorrer a experiência para atestar sua veracidade — e.g., que o fogo é quente não se pode saber a priori.
} 
parte pura é chamada de Moral «Moral», ou Metafísica dos Costumes, e sua parte empírica de Antropologia.

É nesse sentido, portanto, que deve ser compreendida a metafísica relativa aos costumes: como um sistema de conhecimentos a priori que tem por objeto determinado a liberdade do arbítrio (MS, VI:216).

\title{
1.1.2. A teoria e a prática: a política como doutrina prática
}

Dá-nos conta Kant que a definição do que seja a teoria e do que seja a prática modifica-se de acordo com o objeto que se pretende conhecer ${ }^{19}$. Há três tipos possíveis de objetos com o quais se pode lidar: primeiramente, os objetos empíricos que se dão em uma experiência possível (os objetos relacionados à natureza); em seguida, os objetos puros da intuição (os objetos da matemática); e, enfim, os objetos que só se representam mediante conceitos (os objetos da filosofia). Essa diferenciação nada mais é que a marca distintiva da filosofia crítica: precisar e reconhecer os objetos com os quais a razão lida; por um lado, objetos que, uma vez que são dados na experiência possível, podem ser conhecidos com certeza e, de outro lado, objetos que podem ser pensados, mas não podem ser conhecidos posto que não são dados na experiência. $\mathrm{O}$ tratamento que interessa a esta investigação é aquele que se dá aos objetos puramente conceituais, pois a moral kantiana encontra seu fundamento no conceito de dever.

De maneira geral e ainda sem efetuar a divisão segundo os objetos,

\begin{abstract}
chama-se mesmo teoria a um conjunto de regras práticas quando estas regras são pensadas como princípios numa certa universalidade. (...) Inversamente, denomina-se prática não a toda execução «Hantirung», mas apenas a efetuação de um fim conseguida como adesão a certos princípios de conduta representados na sua generalidade (TP, VIII:275, passim).
\end{abstract}

Vê-se que a prática, ainda que de maneira abrangente, não é uma execução de qualquer tipo. O mero fazer, o mero executar que não envolva um ato da faculdade de julgar não é prática em sentido estrito:

É evidente que entre a teoria e a prática se exige ainda um elemento intermediário de ligação e de passagem «Überganges» de uma para a outra, por mais completa que possa ser a teoria; com efeito, ao conceito de entendimento, que contém a regra, deve-se acrescentar um ato da faculdade de julgar, mediante o qual o prático distingue se algo é ou não um caso da regra (TP, VIII:275).

\footnotetext{
19 Dado o escopo preciso que necessitamos do assunto para avançar nesta investigação, trataremos da questão primariamente a partir da introdução do tratado Sobre a expressão corrente: isto pode ser correto na teoria, mas nada vale na prática (TP, VIII: 275-278). Aconselha-se também consultar paralelamente os capítulos sobre o cânone da razão pura (KrV, B823-859) e, especialmente, sobre a arquitetônica da razão pura (KrV, B860-879) a fim de comparar o tratamento que o tema teve.
} 
As três condições, que devem concorrer concomitantemente, para caracterizar uma ação prática podem ser elencadas assim: (1) a necessidade da ação ser uma realização orientada por um fim; (2) a necessidade de estar ligada a princípios de conduta e não a um fazer de acaso; e (3) a necessidade de um ato da faculdade de julgar ou, especificamente, da ação resultar de um juízo reflexivo. Há, portanto, indubitavelmente uma interdependência entre a teoria e a prática: diz Kant $^{20}$ que ninguém se pode pretender versado na prática de uma ciência ao desprezar a teoria sem deixar claro que é um ignorante no seu ramo, bem como um teórico cuja faculdade do juízo é deficiente poderia nunca se tornar um prático em seu campo do saber.

Para campos do saber que lidam com os objetos do conhecimento que são empiricamente dados (tal como a física), a passagem da teoria à prática não representa mais um problema filosófico tão intrincado na seara da filosofia crítica. Ainda no esteio da doutrina crítica, por sua raiz na intuição, até mesmo os objetos matemáticos não representam em si um problema de monta e isso se deve mesmo à sua natureza: a segurança dos objetos matemáticos reside no fato de que as fontes desse conhecimento se encontram nos princípios puros e verdadeiros da razão; a intuição pura, destarte, é livre de falhas.

O ponto de tensão na questão da teoria e da prática orbita, portanto, em relação aos objetos que só se representam mediante conceitos, como é o caso da moralidade: a moral é uma teoria que se funda sobre o conceito de dever. Como se poderia, nesse caso, avaliar a correção da prática?

Uma teoria cujos objetos só se representam mediante conceitos está mais suscetível a tornar-se uma idealidade vazia ${ }^{21}$ : então seria o caso de o dito comum estar correto e toda a teoria

\footnotetext{
20 TP, VIII:276.

${ }^{21}$ A expressão "idealismo vazio" levou Philonenko (Theorie et Praxis dans la pensée de Kant et Fichte en 1793. Paris: Vrin, 2000) a aproximar Kant de Platão na questão da teoria e da prática. A análise final de Philonenko é ter havido uma mudança na maneira que Kant se aproximava da questão do idealismo na política. Divide sua análise entre forma e conteúdo: do ponto de vista da forma a interdependência entre a teoria (que dá os princípios mais gerais) e a prática (que se desdobra na consecução da teoria) tudo funciona perfeitamente bem; do ponto de vista do conteúdo, a doutrina kantiana fracassa em unir teoria e prática (Philonenko, 2000, pp. 69-73) e isso força o filósofo a tomar um outro rumo - deixar de acreditar na natural efetivação da teoria pela prática e se mover no sentido de buscar estabelecer saídas para que a efetivação realmente ocorra. Noutras palavras, Kant seria obrigado a adiar o sonho da realização in concreto da teoria. O ponto nevrálgico dessa mudança de perspectiva é explicitado ao tratar da origem do Estado dois anos depois que o tratado de 1793, n'À paz perpétua (em 1795): o ato da criação do Estado não decorre da moralização do homem e nem é símbolo dela, mas é fruto meramente da necessidade natural de sobrevivência. O trecho que Philonenko invoca é aquele relativo ao povo de demônios localizado no primeiro suplemento d'À Paz Perpétua - que trata da garantia da paz: "o problema do estabelecimento do Estado, tão duro como isso soe, pode ser solucionado mesmo no caso de um povo de demônios (se somente eles tiverem entendimento) e exprime-se assim: 'ordenar uma multidão de seres racionais, que no todo exigem leis universais para sua conservação, das quais, porém, cada um está inclinado a eximir-se em segredo, e estabelecer sua constituição de modo que, embora tentem uns contra os outros em suas disposições privadas, as contenham uns aos outros de modo que o resultado em sua conduta pública seja justamente o mesmo como se não tivessem nenhuma das tais más disposições’ Pois não é o aperfeiçoamento moral dos homens, mas somente o mecanismo da natureza, do qual é exigida a tarefa de conhecer como se pode utilizá-lo nos homens para dirigir de modo tal o conflito das disposições hostis num povo que eles mesmos forcem uns aos outros a submeter-se a leis de coerção e assim tenham de conduzir ao estado de paz, no qual as leis têm força" (ZeF, VIII:366). Afirma Philonenko que até 1793, portanto ainda na escrita do tratado sobre a Teoria e Prática, acreditava Kant na síntese perfeita entre a teoria e a prática e, portanto, na completa realização da teoria; confrontou-se em certa
} 
não passar de um palavrório guiado por boas intenções, mas que não se ajusta ao mundo real — constatar-se-ia que tais conceitos ou são inúteis para a prática ou causariam mais dano que benefício se tentados ser praticados. Duas figuras surgem com segurança à mente em um paralelo frutífero junto aos dois apêndices d'À paz perpétua (os quais, a descrever os títulos, descortinamos também a estratégia adotada pelo filósofo na questão da teoria à prática nos assuntos da filosofia moral: o primeiro apêndice faz uma constatação do estado da arte acentuando o desacordo entre a moral e a política e o segundo apêndice trata de harmonizar a moral com a política): se a teoria é um palavrório bem intencionado, mas vazio, a política fica à guisa do moralista político e às suas práticas - pois o moralista afirma que não há teoria para a política; se, entretanto, for possível estabelecer uma teoria e um método de mensurar a prática, então o político moral pode afirmar com certeza que a política e a moral devem andar unidas de tal forma que a primeira não dê um passo sem prestar reverência à segunda. A mesma ideia se corrobora no Suposto direito de mentir por amor à humanidade: "o direito nunca se deve adaptar à política, mas é a política que sempre deve se ajustar ao direito" (VRML, VIII:429).

O problema é resolvido da seguinte maneira:

com efeito, aqui havemo-nos com o cânone da razão (no campo prático), onde o valor da prática se funda inteiramente na sua conformidade com a teoria que lhe está subjacente (TP, VIII:277 - grifo nosso)

O conceito de dever não é qualquer espécie de conceito: é um conceito do uso prático da razão - o uso prático da razão não é dialético como o uso especulativo e, portanto, comporta um cânone (um conjunto abrangente de princípios a priori do uso correto de certas faculdades do conhecimento em geral). Se a prática não é uma mera execução cega, se exige as três condições fundamentais para ser chamada de fato prática (estar orientada por um fim, estar ancorada em princípios de conduta explícitos e dar-se mediante um ato da faculdade de julgar), sua correção só pode ser determinada pela sua irrestrita fidedignidade à teoria.

\footnotetext{
altura com a questão do "povo de demônios" e se viu obrigado a postergar a conta-gotas o sonho da realização da teoria pela via do direito - o autor se refere à futura Metafísica dos Costumes (de 1797). Não compartilhamos de todo a posição de Philonenko, especialmente pelo fato das ideias expressas na garantia da paz já terem sido trabalhadas no opúsculo da Ideia universal de um ponto de vista cosmopolita (anterior nove anos ao tratado sobre a teoria e a prática que o autor se debruça em sua análise), no entanto concordamos em um aperfeiçoamento da doutrina que conduz a um aclaramento maior, por parte de Kant, dos "dispositivos técnicos" necessários para a consecução da teoria pela prática; para utilizar-se de uma fórmula bem acabada da filosofia da história kantiana, tais "dispositivos técnicos”, entendidos especialmente como o direito político, podem ser reconhecidos à maneira de "condição facilitadora" para a moralidade - coaduna-se, nessa interpretação, a filosofia da história ao trecho de análise d'À paz perpétua supratranscrito. Cf. Também a introdução da dissertação de mestrado de Luiz Paulo Rouanet (A paz perpétua: estudo sobre o pensamento político kantiano. Dissertação (mestrado) — Departamento de Filosofia, Faculdade de Filosofia, Letras e Ciências Sociais. USP. São Paulo, 1993, pp. 03-10).
} 
Deve-se reconhecer uma progressão no pensamento kantiano relativamente à questão da teoria e da prática na política: alguns intérpretes ${ }^{22}$ são unânimes em colocar nos apêndices $d$ 'À paz perpétua a forma final ou, noutras palavras, a conclusão das reflexões que se iniciaram no Teoria e prática (as quais ora apresentamos) - se no escrito mais antigo a questão era excessivamente teórica e abstrata, n'À paz perpétua ganha nitidez o ponto ao qual o filósofo quer chegar. Ali n'À paz perpétua, a palavra "política" aceita uma dupla distinção: enquanto uma técnica autônoma que vise lidar com forças sociais já existentes e orientada por finalidades egoísticas (é o jogo político efetivo) e enquanto uma doutrina metafísica cujo esforço é a mediação entre a doutrina do direito e os problemas empíricos. Os moralistas políticos são aqueles que "em lugar da prática, de que se gabam estes estadistas astuciosos, lidam com práticas" (ZeF, VIII:373), noutras palavras, lidam com o jogo político de interesses casuísticos; é o prático que desdenha da teoria. Aquele que faz a passagem entre a teoria e o problema empírico é o político moral, de maneira que para ele

\begin{abstract}
se forem encontrados defeitos na constituição do Estado ou na relação entre Estados que não se pôde prevenir, então é dever, sobretudo para os chefes de Estado, estar atento a partir daí a como pode ser melhorada, tão logo quanto possível, e ser adequada ao direito natural, tal como ele figura aos nossos olhos como modelo na ideia da razão (ZeF, VIII:372).
\end{abstract}

A tarefa do filósofo — que aqui se identifica com o político moral — consiste em "passar de uma metafísica do direito (que abstrai de todas as condições da experiência) a um princípio da política (que aplica estes conceitos aos casos da experiência) e por meio deste chegar à solução de uma tarefa da política" ${ }^{23}$.

\title{
1.2. O sistema moral
}

Conforme afirmamos anteriormente, há dois sentidos para se compreender os termos "moral" e "moralidade"; Kant constantemente intercala esses usos em suas obras. Em um sentido estrito, os termos se referem ao valor de uma ação: uma ação moralmente boa é aquela que toma o dever como móbil, correspondendo ao imperativo ético "fazer o dever por dever". É o sentido amplo de moralidade que interessa no tocante às relações internas das partes do sistema da filosofia prática: tem a ver com o campo amplo da liberdade ou, mais especificamente, às leis da liberdade.

\footnotetext{
${ }^{22}$ MARCOS, Maximiliano Hernández. "Política y antropología en Kant”. In: SANTOS, Leonel Ribeiro; ANDRÉ, José Gomes. Filosofia kantiana do direito e da política: seminário internacional. Lisboa: Universidade de Lisboa, 2007, pp. 65-100.

${ }^{23}$ VRML, AA VIII:429. As noções abstratas de "prática" do Teoria e prática são interpretadas por Marcos (op. cit., pp. 68-71) noutras palavras; segundo ele, a expressão "teoria prática do direito" como a consecução de duas noções: do idealismo moral universal lapidado por um realismo político contingente. Isso significa que a ação política tem de ser derivada de uma teoria normativa do dever específica, a saber, baseada em princípios racionais puros da ideia de liberdade; em segundo lugar, que "a idealidade moral dos princípios tem de ser complementada e restringida pelo realismo político dos meios e das condições fáticas de seu traslado efetivo a uma determinada sociedade humana".
} 
Esse entendimento relaciona-se com a filosofia crítica haver feito, desde seu estabelecimento mais elementar, uma distinção entre as leis da natureza e as leis da liberdade — a legislação da liberdade é a legislação "moral”, cujas leis são ditas leis práticas puras, seus fins são dados a priori pela razão e não são empiricamente condicionadas $^{24}$. A liberdade é uma só; contudo, pode-se reconhecer dois tipos de legislações - uma legislação que diz respeito à liberdade interna do sujeito e a qual chamamos de legislação ética; outra legislação que diz respeito à liberdade externa e que chamamos de jurídica:

Essas leis da liberdade, à diferença das leis da natureza, chamam-se morais «moralisch». $\mathrm{Na}$ medida em que se refiram às ações meramente exteriores e à conformidade destas à lei, elas se chamam jurídicas «juridisch»; mas, na medida em que se exijam que elas próprias devam ser os fundamentos de determinação das ações, então são éticas «ethisch» (MS, AA VIII:213).

Um ponto de interesse para esta investigação, no tocante à filosofia moral kantiana, diz respeito à articulação das obras do núcleo crítico originalmente publicado ${ }^{25}$; em nosso caso específico, a tarefa de articulação se restringe àquela entre a Fundamentação da Metafísica dos Costumes e a própria Metafísica dos Costumes. Alguns comentários acentuam o peso do caráter iminentemente ético que se imprimiu à Fundamentação da Metafísica dos Costumes, de maneira que, apesar de ser uma obra sobre a moral em sentido amplo, acabou por enfraquecer os elementos jurídicos do sistema - efeito que só seria corrigido na Introdução da Metafísica dos Costumes: essa questão incidental leva a relevantes reformulações de uma obra à outra e dessas mudanças se acentuam as tensões no interior do sistema dos costumes; o resultado dessas tensões, irreconciliáveis e cuja resolução seria a retirada completa do direito do interior do sistema dos $\operatorname{costumes}^{26}$ (o que seria ir contra a própria ambição original da Metafísica dos Costumes de ser um sistema abrangente e consistente dos deveres em geral), conduz a questionamentos recorrentes sobre a pertença ou não da doutrina do direito à doutrina universal dos costumes. Um dos argumentos é que do princípio supremo da moralidade não se pode deduzir os deveres jurídicos tomados unicamente como deveres jurídicos.

A questão preliminar na articulação de ambos os textos é pacificar o uso de termos distintos que apontam para um mesmo objeto - essa tarefa por si já desfaz mal-entendidos interpretativos,

\footnotetext{
${ }^{24} \mathrm{KrV}, \mathrm{B} 828$.

${ }^{25}$ Compreendemos pela expressão "núcleo crítico originalmente publicado" o grupo dos trabalhos oficiais publicados em vida pelo filósofo. A Akademieausgabe von Immanuel Kants Gesammelten Werk, conhecida também como "edição da Academia", pauta-se pela proposta de oferecer reunida toda a obra escrita kantiana conhecida e outros textos não publicados em vida pelo autor também estão disponíveis. Assim, há outras fontes de estudo da moral ou do direito para além das obras publicadas — desde anotações e reflexões de próprio punho à margem das páginas até anotações feitas por alunos de cursos ministrados. Por exemplo, algumas questões desta pesquisa poderiam ser abordadas pelas Preleções sobre a moral, Preleções sobre a pedagogia ou Direito Natural Feyrabend.

${ }^{26}$ Cf. WILLASCHEK, Markus. "Porque a Doutrina do Direito não pertence à Metafísica dos Costumes: sobre algumas distinções básicas na filosofia moral de Kant”. In: TRAVESSONI, A. Kant e o Direito. Belo Horizonte: Mandamentos, 2009, pp. 257-259.
} 
como veremos oportunamente. Desta maneira, compreendemos que "moral em sentido amplo" e "doutrina universal dos costumes" têm o mesmo significado: o sistema moral duplamente articulado em seu interior entre a doutrina ética e a doutrina do direito em seu caráter teorético. Como também as expressões "princípio supremo da moral", "princípio supremo da moralidade"27 e "princípio supremo da doutrina dos costumes" apontam todas para o imperativo categórico: àquela recomendação prática de agir somente sob o império de uma máxima que ao mesmo tempo possa ser aceita como legislação universal.

Nem todo problema interpretativo se esvai com o aclaramento preliminar dos termos: alguns desses problemas persistem em decorrência de uma real mudança no trato de alguns pontos por Kant. O caráter acentuadamente ético da Fundamentação da Metafísica dos Costumes e a suposta correção kantiana na Metafísica dos Costumes orbitam em torno de três eixos: primeiramente, a ênfase do arbítrio em detrimento da vontade; em segundo lugar, o deslocamento da centralidade do critério de avaliação da ação deixar de ser o dever para ser a legislação, expresso pela substituição do par "ação conforme ao dever" e "ação por dever" pelo par "legalidade" e "moralidade"; por fim, a inserção explícita de noções que não haviam ficado suficientemente claras e que acentuam a maior proximidade da doutrina dos costumes ao discurso jurídico. É interessante notar que tais diferenciações dão o tom a toda a obra, vez que se encontram na Introdução mais geral à Metafísica dos Costumes e não nas introduções específicas de uma ou outra doutrina constitutiva dos costumes: fica pressuposta a jurisdição em toda a doutrina dos costumes dessas diferenciações.

Vale a pena recuperar a continuação do trecho que estabelece a ligação das leis da liberdade às leis morais. Assim, na Metafísica dos Costumes lemos que:

Essas leis da liberdade, à diferença das leis da natureza, chamam-se morais. Na medida em que se refiram às ações meramente exteriores e à conformidade destas à lei, elas se chamam jurídicas; mas, na medida em que se exijam que elas próprias devam ser os fundamentos de determinação das ações, então são éticas. Diz-se, portanto: a concordância com as primeiras é a legalidade, com as segundas a moralidade da ação.A liberdade a que se referem as primeiras leis só pode ser a liberdade no uso externo do arbítrio, enquanto aquela a que se referem as últimas pode ser a liberdade em seu uso tanto externo como interno, contanto que ela seja determinada pela lei da razão (MS, AA VI:213 - grifos nossos).

Essa é a primeira aparição da definição de legalidade «Gesetzmässigkeit» e moralidade «Sittlichkeit». É estabelecido o critério e sua amplitude para cada tipo de legislação. A liberdade

\footnotetext{
${ }^{27}$ Kant é enfático em tratar o princípio supremo da moralidade como autonomia da vontade: "a autonomia da vontade é o princípio supremo da moralidade «Sittlichkeit»", diz na Fundamentação da Metafísica dos Costumes (GMS, AA IV:440). Mas que seria o princípio de autonomia da vontade senão a aplicação do imperativo categórico? Se quiséssemos proceder a uma diferenciação, deveríamos pensar o imperativo categórico em uma posição superior como princípio supremo da moral e o princípio de autonomia da vontade um nível abaixo (porque decorrente dele) como o princípio supremo da moralidade.
} 
no seu uso externo deve meramente concordar com as leis; é jurídica, portanto. Ao passo que o uso da liberdade interna do arbítrio é dita moral e o critério de moralidade pode abranger as considerações do agir em seu uso tanto externo quanto internamente - que se quer dizer com isso se aclara com o confrontamento da segunda passagem em que Kant aborda a diferenciação entre legalidade e moralidade:

A mera concordância ou discrepância de uma ação com a lei, sem consideração com o móbil da mesma, denomina-se legalidade (conformidade à lei), mas aquela em que a ideia do dever pela lei é ao mesmo tempo o móbil da ação se chama moralidade (eticidade) da mesma (MS, AA VI:219 - grifos nossos).

A moralidade da ação é um critério mais vinculante, porém menos abrangente; é mais vinculante na medida que, vez extraída a legislação que permite uma coação ao nãocumprimento de uma obrigação, resta ainda o dever ético do seu cumprimento por parte do sujeito contraente da obrigação: se efetuou um empréstimo mediante um título com caráter de confissão de dívida que se mostre ineficaz juridicamente, o contraente que tomou o empréstimo ainda tem a obrigação ética de pagar seu credor. A maior abrangência fica por conta da legalidade da ação, visto que toda ação moral deve necessariamente ser legal do ponto de vista da legislação prática; é o mesmo que se passava na Fundamentação da Metafísica dos Costumes: toda a ação por dever é, necessariamente, uma ação conforme ao dever. A menor amplitude dos deveres jurídicos (que serão referidos como estritos ou restritos) frente aos deveres de virtude (amplos) é estabelecida de maneira negativa, isto é, como condição restritiva da jurisdição de cada uma das legislações do arbítrio:

A legislação ética é aquela que não pode ser externa (quando muito os deveres também podem ser também externos); a jurídica é a que também pode ser externa (MS, AA VI:220).

Para estabelecer o par de critérios legalidade/moralidade, Kant é obrigado a mudar seu critério de consideração do querer para a legislação. Assim, afirma que:

\footnotetext{
A toda legislação (prescreva ela ações interiores ou exteriores e estas ou a priori, através da mera razão, ou por meio do arbítrio de um outro) pertencem dois elementos: primeiro, uma lei que representa objetivamente como necessária a ação que deve ocorrer, ou seja, que faz da ação um dever; segundo, um móbil que conecta subjetivamente o arbítrio para esta ação à representação da lei (MS, AA VI:218).
}

O móbil da ação, que na Fundamentação da Metafísica dos Costumes era elemento presente tanto nas ações conformes ao dever quanto realizadas por dever, não é considerado para o critério de legalidade. O móbil da ação interessa em uma perspectiva ética, mas é irrelevante do ponto de vista jurídico.

Eis que uma metafísica se legitima no campo da filosofia prática: 
Se um sistema de conhecimentos a priori por meros conceitos, assim, chama-se metafísica, então uma filosofia prática, que tem por objeto não a natureza, mas a liberdade do arbítrio, irá pressupor e requerer uma metafísica dos costumes (MS, VI:216).

Cabe chamar a atenção para a função de passagem «Übergang» que acompanha a metafísica: a metafísica, para Kant, é um sistema de conhecimentos que se erige a partir de juízos a priori e que, apesar da origem pura na razão, os efeitos serão sentidos de alguma forma no mundo natural $^{28}$. Nesse sentido é que, no Prefácio à Metafísica dos Costumes, a título de exemplo, Kant diz que "mesmo enquanto conceito puro, porém, o conceito de direito é baseado na práxis (a aplicação aos casos que se apresentam na experiência) e, portanto, um sistema metafísico do mesmo precisaria levar também em conta, em sua divisão, a diversidade empírica daqueles casos" (MS, AA VI:205).

\subsubsection{As duas liberdades e sua relação com a moral}

Há dois tipos de liberdades em Kant: a liberdade transcendental ou cosmológica e a liberdade prática. Respectivamente, referem-se à independência da causalidade sensível e à independência de determinação das afecções ${ }^{29}$.

\footnotetext{
${ }^{28}$ Abordar a questão de maneira detida guiaria a abordar a questão das duas liberdades de maneira mais estreita tarefa que anteriormente nos escusamos. Kelsen (Teoria pura do Direito. São Paulo: Martins Fontes, 1999, p. 261) traça um estado da arte resumido sobre a questão em uma nota de rodapé e aqui transcrevemos: "Kant identifica vontade e razão prática e afirma que esta razão tem de, 'como razão prática ou como vontade de um ser racional, ser considerada como livre por si mesma' (Grundlegung zur Metaphysik der Sitten, p. 448). Visto que, assim, é a razão prática que, como vontade, é livre, e a lei moral é estabelecida por esta vontade, vontade esta que, como vontade livre, apenas pode ser uma vontade inteligível, também a lei moral - assim se leva a construção kantiana até o fim - se situa no mundo inteligível. Kant crê poder evitar a contradição entre causalidade e liberdade pela referência da causalidade ao mundo empírico e da liberdade ao mundo inteligível. Mas a imputação produz-se de fato com base numa ordem normativa que regula a conduta do homem empírico e vale no mundo empírico. Só se imputa algo ao homem empírico. Kant diz expressamente (Kritik der reinen Vernunft, pp. 372-73): 'As nossas imputações apenas podem ser referidas ao caráter empírico'; mas afirma também: 'Com respeito a este caráter empírico não há... qualquer liberdade'. A liberdade do homem empírico, única que interessa, crê Kant salvá-la admitindo que o homem empírico, isto é, o homem como fenômeno, e o homem como coisa em si, o homem inteligível, são um e o mesmo ser. Isto, porém, não é possível segundo a representação do próprio Kant da relação entre fenômeno e coisa em si. Com efeito, a coisa em si é a causa ou o fundamento do fenômeno e não pode, por isso mesmo, ser idêntica a este. A contradição entre causalidade e liberdade reside precisamente no fato de se afirmar de uma e a mesma coisa que ela é causalmente determinada e, ao mesmo tempo, que ela é livre, isto é, não causalmente determinada. Kant pode evitar a contradição apenas pelo fato de não referir à mesma coisa causalidade e liberdade, mas referir a causalidade à coisa como fenômeno e a liberdade à coisa em si - portanto, precisamente pelo fato de pressupor que o homem, como fenômeno, não é o mesmo ser que ele designa por homem como coisa em si". O que interessa a nossa investigação é a liberdade prática pelo seu caráter legiforme, porém mister é salientar que o lastro da liberdade prática remanesce no terreno da liberdade transcendental na medida que Kant procedeu à separação fenômeno/natureza, de um lado, e de outro númeno/liberdade.

${ }^{29}$ Não pretendemos nos alongar na diferenciação dessas liberdades e nos pressupostos de cada uma delas à luz da Crítica da Razão Pura, pois foge ao escopo proposto por esta investigação (para maior densidade de análise, cf. ALLISON, Henry. "Practical and transcendental freedom". In: Kant's theory of freedom. New York: Cambridge University Press, 1990, pp. 54-70). Este trecho argumentativo tem a finalidade unicamente de demarcar o tipo de liberdade que interessa à moral (a liberdade prática - como será acentuado adiante) e resgatar a separação crítica dos pontos de vista do mundo fenomênico e mundo numênico. Também foge de nosso objeto de interesse de análise a questão da crítica da razão prática pura; nesse sentido, aceitamos pacificamente a asserção de Kant que "só conhecemos nossa própria liberdade (da qual procedem todas as leis morais, portanto também todos os direitos, assim como os deveres) através do imperativo moral, que é uma proposição que ordena o dever e a partir da qual pode ser
} 
Pela via da liberdade transcendental, Kant se limitava a garantir a possibilidade lógica de se pensar a liberdade como não estando em contradição latente com a causalidade natural; esse é um tema, por excelência, ligado ao empreendimento da primeira Crítica - cabe à razão teórica demonstrar a não-contradição. Isso se passa na problemática da terceira antinomia ${ }^{30}$. A possibilidade de pensar uma liberdade causal reside em projetar a si mesmo como ser pertencente a um mundo numênico e que, em decorrência disso, tem a capacidade de abstrair-se da necessidade de causação natural. Do ponto de vista da razão teórica, então, a liberdade pode ser pensada, mas não conhecida (em razão de não ser dada na experiência). Nesse sentido, "a razão especulativa não funda a filosofia moral, mas permite seu desenvolvimento ao mostrar que não há contradição entre a liberdade e as leis da natureza" 31 .

Contudo, é a liberdade prática que interessa liminarmente à moralidade: em sentido prático, liberdade é definida como a independência do arbítrio livre em estabelecer seus fins. Uma das marcas distintivas da liberdade do homem é, portanto, a sua capacidade de se propor fins e esta capacidade está intimamente ligada ao arbítrio $^{32}$, cuja representação de um fim insta-o no sentido de realizar uma ação prática com a finalidade de produzir o objeto representado ${ }^{33}$. Essa faculdade, devemos estabelecer esse paralelo, é expressa naquela definição dita negativa de liberdade que Kant dá conta na terceira seção da Fundamentação da Metafísica dos Costumes:

A vontade é uma espécie de causalidade de seres vivos na medida em que são racionais, e a liberdade seria aquela propriedade dessa causalidade na medida em que esta pode ser eficiente independentemente da determinação de causas alheias (GMS, AA IV:446)

A liberdade não pode ser definida unicamente de maneira negativa, pois senão seria afirmar que liberdade é simplesmente anomia. A definição da liberdade como independência de determinação de causas alheias é uma definição simplesmente negativa de liberdade; dessa explicação se pode extrair um conceito positivo, a saber,

a liberdade, embora não seja uma propriedade da vontade segundo leis naturais, nem por isso é de todo sem lei, mas, antes pelo contrário, tem de ser uma causalidade segundo leis

desenvolvida, depois, a faculdade de obrigar aos outros, isto é o conceito do direito" (MS, AA VI:239) visto que se coaduna com a posição apresentada na terceira seção da Fundamentação da Metafísica dos Costumes também.

${ }^{30}$ Cf. KrV, B472/473; a solução do problema, que aponta para uma ilusão transcendental (cf. KrV, B529/530) e é ligada à natureza arquitetônica da razão, que guia naturalmente a aceitar a tese em favor da liberdade (cf. KrV, B502/502). A solução do problema, como se verá, é alcançada com a diferenciação crítica entre os caráteres empírico e inteligível (cf. KrV, B560/586). Para a diferenciação entre phaenomena e noumena: cf. KrV, B306/313.

${ }^{31}$ NOUR, 2004, p. 16.

${ }^{32}$ A exposição principal que se segue no texto acompanha o conteúdo tal qual consta na argumentação da Metafísica dos Costumes. Kant é enfático em acentuar o papel proeminente do arbítrio na Metafísica dos Costumes, ao passo que sempre se refere à vontade na Fundamentação da Metafísica dos Costumes — o trecho que podemos estabelecer um paralelismo à questão de dar-se fins é este: "a vontade é pensada como uma faculdade de se determinar a si mesma a agir em conformidade com a representação de certas leis. E uma tal faculdade só pode ser encontrada em seres racionais. Ora, o que serve à vontade como fundamento objetivo de sua autodeterminação é o fim, e este, se é dado pela mera razão, tem de valer igualmente para todos os seres racionais. O que, ao contrário, contém tão-somente o fundamento da possibilidade da ação cujo efeito é um fim, é o que se chama meio" (GMS, AA IV:427).

${ }^{33}$ Cf. MS, AA VI:381. 
imutáveis. (...) O que pode ser, então, a liberdade da vontade senão autonomia, isto é, a propriedade da vontade de ser para si mesma uma lei? (GMS, AA IV:446-447, passim).

A capacidade do arbítrio de dar-se fins ${ }^{34}$ é uma capacidade racional, pois necessita representar o fim desejado e buscar meios de produzi-lo: isso seria o mesmo que dizer que o homem age praticamente, visto que age segundo princípios com a finalidade de consecução de um fim. Para fins em geral, é o caso de utilizar-se de um cálculo de meios e fins: "se quero tal, devo fazer isso e isso" - a medida para a consecução do fim não é senão um imperativo hipotético. A faculdade prática da razão exige a racionalidade justamente para derivar ações dos princípios - se para executar uma ação não se exige a racionalidade, mas somente o mero instinto, essa não é uma ação prática: é um mero guiar-se pela natureza. O "modelo da razão" (especialmente aqui em seu uso prático), nas palavras de O’Neill, é uma "legiformidade sem leis"35: o método mais fundamental da razão é iminentemente legiforme ainda que o conteúdo das leis venha a ser definido depois; Ricardo Terra ${ }^{36}$ faz referências a um modelo procedimental sem ser um algoritmo nem ter valores fixos estabelecidos previamente. A ideia de uma legiformidade básica inicialmente vazia de conteúdo permite compreender a afirmação de Kant que:

à ideia de liberdade está inseparavelmente ligado o conceito de autonomia, a este, porém, o princípio universal da moralidade, o qual subjaz, na ideia, a todas as ações de seres racionais, do mesmo modo que a lei natural a todas as aparências (GMS, IV:452-453).

O princípio universal da moralidade, a que Kant faz referência, é o princípio da autonomia da vontade; por sua vez, ligado ao imperativo categórico da Fundamentação da Metafísica dos Costumes ("age apenas segundo a máxima pela qual possas ao mesmo tempo querer que ela se torne uma lei universal" ${ }^{37}$ ) ou o princípio supremo da doutrina dos costumes ("aja segundo uma máxima que possa valer ao mesmo tempo como lei universal" ${ }^{38}$ ). O imperativo categórico é um único, afirma Kant, ao mesmo tempo que apresenta algumas variantes: a formulação da autonomia, que aponta para "a ideia da vontade de todo ser racional enquanto vontade universalmente legisladora" ${ }^{39}$, é uma dessas variantes. Daí dizer Kant que à ideia de liberdade se liga o conceito de autonomia - é o sujeito que preencherá o conteúdo das leis.

Com a centralidade da análise na capacidade de propor-se fins, a diferença entre o direito e a ética pode ser traçada novamente a partir dessa faculdade:

\footnotetext{
${ }^{34}$ A liberdade prática é trabalhada anteriormente na Dialética e no Cânone da Crítica da Razão Pura em termos similares de uma independência do arbítrio livre e sua contraposição é feita com relação à determinação do arbítrio bruto por causas naturais como o instinto.

${ }^{35}$ O'NEILL, O. "Autonomia, pluralidade e razão pública". In: Cadernos de Filosofia Alemã, v. 19, n. 1, Jan-Jun/2014, p. 30.

36 TERRA, 2004, pp. 12-13.

${ }^{37}$ GMS, AA IV:421.

${ }^{38}$ MS, AA VI:226.

${ }^{39}$ GMS, AA IV:431. Essa é a primeira versão da formulação da autonomia na Fundamentação da Metafísica dos Costumes.
} 
É possível pensar a relação do fim com o dever de duas maneiras: ou partindo do fim para descobrir a máxima das ações conformes ao dever, ou, inversamente, começando desta para descobrir o fim que é ao mesmo tempo dever. A doutrinado do direito segue o primeiro caminho (MS, AA VI:382-383).

A diferenciação a ser feita é bastante simples: ninguém pode ser coagido externamente a ter um fim porque o fim é um ato da liberdade do arbítrio - o sujeito racional deve propor por si e a si mesmo seus fins. Apesar de ser impossível a coação externa com a finalidade de dar um fim a outrem, há um tipo específico de fim que é ao mesmo tempo um dever: esses fins não comporiam a doutrina do direito por extrapolarem a jurisdição das obrigações jurídicas; esses fins, que são ao mesmo tempo dever, têm de pertencer à ética posto que ela é "a única que traz consigo em seu conceito a autocoerção segundo leis (morais)" $" 40$.

\subsubsection{A doutrina universal dos costumes ("Philosophia practica universalis")}

$\mathrm{Na}$ Introdução à Metafísica dos Costumes, é curioso notar que o filósofo usa o título de "Philosophia practica universalis" para retomar toda a fundamentação comum à doutrina universal dos costumes. O leitor da Fundamentação da Metafísica dos Costumes há de se lembrar dessa expressão no prefácio daquela obra em uma referência de apreciação crítica à obra de Christian Wolff: "não se pense, porém, que o que é exigido aqui já se encontre na propedêutica do célebre Wolff à sua filosofia moral, a saber, a que intitulou Filosofia prática universal, e que aqui, pois, não se tenha precisamente nada de novo". Adiante, explica a sua censura: a filosofia moral "deve investigar a ideia e os princípios de uma possível vontade pura e não as ações e condições do querer humano em geral, as quais são extraídas da Psicologia" (GMS, AA IV:390) - ou seja, a fundamentação da filosofia moral deve ser o oposto e estabelecer-se a partir de juízos a priori.

O que nos propomos aqui é resgatar os elementos mínimos da moralidade em sentido alargado e para tanto seguiremos de perto o texto kantiano. A primeira distinção é entre arbítrio e vontade:

as leis procedem da vontade; as máximas, do arbítrio. Este último é, no homem, um livrearbítrio; a vontade que se refere apenas à lei não pode ser denominada nem livre nem não livre, porque ela não se refere às ações, mas imediatamente à legislação para as máximas das ações (portanto à razão prática mesma), e por isso é absolutamente necessária e insuscetível, ela mesma, de necessitação. Somente o arbítrio, portanto, pode ser denominado livre (MS, AA VI:226).

A doutrina universal dos costumes oferece duas legislações práticas segundo sua divisão. Qualquer que seja essa legislação

(prescreva ela ações interiores ou exteriores e estas ou a priori, através da mera razão, ou por meio do arbítrio de um outro) pertencem dois elementos: primeiro, uma lei que

\footnotetext{
${ }^{40}$ MS, AA VI:381.
} 
representa objetivamente como necessária a ação que deve ocorrer, ou seja, que faz da ação um dever; segundo, um móbil que conecta subjetivamente o fundamento de determinação do arbítrio para esta ação à representação da lei (MS, AA VIII:218).

Estamos novamente de frente com a divisão entre a ética e o direito; desta vez não em função do fim (fim em geral ou fim que é ao mesmo tempo dever) nem do tipo de obrigação (dever jurídico ou dever de virtude), mas centrando-nos na relação entre os polos da lei em uma ponta e na ação noutra ponta. Havemo-nos aqui com uma característica própria da Metafísica dos Costumes que é uma espécie de anterioridade do direito frente à virtude. Essa perspectiva põe como critério mais fundamental a legalidade da ação, isto é, sua conformidade ao dever:

A mera concordância ou discrepância de uma ação com a lei, sem consideração ao móbil da mesma, denomina-se legalidade (conformidade à lei), mas aquela em que a ideia do dever pela lei é ao mesmo tempo o móbil da ação se chama moralidade (eticidade) da mesma (MS, AA VIII:219).

No mesmo trecho, Kant destaca que a legislação externa é dita jurídica e a legislação que não é externa é dita ética ${ }^{41}$. A legislação ética não pode ser externa, contudo os deveres da ética podem ser deveres externos: todos os deveres pertencem à ética, mas a legislação que lida com esses deveres não necessariamente tem de ser a ética (se sua não-obediência interfere na coletividade $)^{42}$. É o caso do cumprimento de um contrato: vez que se haja empenhado a palavra nos termos de um contrato, o dever de cumpri-lo é em última análise um dever ético; contudo, como o contrato envolve um acordo entre vontades, tem-se o direito de obrigar ao cumprimento daquele contrato e o dever de cumpri-lo. Assim, a legislação que rege esse dever é preferencialmente jurídica - sem a exclusão do dever ético que suplanta o jurídico e concorre com ele concomitantemente. Assim se pronuncia Kant:

A ética ensina somente o seguinte: se também é suprimido o móbil que a legislação jurídica une com aquele dever, a saber, a coerção externa, a ideia do dever sozinha já é suficiente como móbil. Pois se não fosse assim, se a legislação mesma não fosse jurídica, se o dever que dela nasce não fosse propriamente, portanto, um dever jurídico (à diferença de um dever da virtude), então o cumprimento da fidelidade (conforme a promessa em um contrato), as ações de benevolência e a obrigação em relação a elas se colocariam em uma mesma classe, o que de modo algum deve ocorrer (MS, AA VI:220).

O que muda entre o direito e a ética é o modo de obrigação: o sujeito racional percebe uma necessitação da razão como um mandamento que comanda; a formulação desse mandamento é o imperativo categórico (o único imperativo incondicional e, portanto, aquele que diz respeito à moral porque se refere unicamente à forma da lei).

Obrigação é a necessidade de uma ação livre sob um imperativo categórico da razão (MS, AA VI:222).

\footnotetext{
${ }^{41}$ MS, AA VI:220.

${ }^{42}$ MS, AA VI:220.
} 
A matéria da obrigação é o dever e, por dever, compreende-se a ação a qual se está obrigado. Um imperativo em geral não é em si mesmo uma lei prática propriamente, mas apenas uma regra prática que torna necessária uma ação até então subjetivamente contingente - o imperativo categórico é um imperativo diferente, pois é de fato uma lei prático-moral. Daí porque o imperativo categórico ser referenciado como o imperativo moral: o imperativo categórico não traz um fim, mas torna a ação subjetivamente contingente em obrigação, isto é, em dever.

O princípio que torna certas ações em dever é uma lei prática. A regra que o agente elege como princípio para si mesmo a partir de fundamentos subjetivos chama sua máxima; donde as máximas dos agentes poderem, em uma mesma lei, ser contudo muito diferentes (MS, AA VI:225)

Forma-se uma tipologia de deveres conforme a relação entre dever e lei: deveres perfeitos ou estritos são deveres jurídicos e deveres imperfeitos ou amplos são deveres de virtude; os deveres se relacionam ao sujeito mesmo ou em relação aos outros — isso não quer dizer que essa divisão remeta imediatamente à divisão entre ética e direito, pois há deveres para consigo mesmo que são jurídicos (da humanidade em nossa própria pessoa) e outros que são éticos (o fim da humanidade em nossa pessoa), bem como deveres para com os outros igualmente jurídicos (o direito dos homens) e éticos (o fim dos homens).

O imperativo categórico (cujo efeito é determinar o arbítrio através da ideia de qualificar sua máxima à universalidade como critério de pertencimento à moral da pretensão contida sob a formulação da máxima) e o princípio supremo da doutrina dos costumes são uma única e mesma coisa:

Aja segundo uma máxima que possa valer ao mesmo tempo como lei universal (MS, AA VI:226) ${ }^{43}$

Ainda sobre leis práticas morais, Kant estabelece uma distinção entre a legiferação e a autoria:

Aquele que comanda (imperans) através de uma lei é o legislador (legislator). Ele é o autor da obrigatoriedade conforme a lei, mas nem sempre o autor da lei. No último caso, a lei seria positiva (contingente) e arbitrária (MS, AA VI:227).

$\mathrm{O}$ ato de legiferar confere o poder de comandar. Aqui reside uma chave interpretativa para o que foi dito anteriormente sobre a ética e o direito diferirem-se quanto ao modo de obrigação: na lei jurídica, o legislador não é o autor da lei e daí segue que a lei positiva do direito não tem a mesma força vinculante e obrigatória da lei da vontade e que, também, o móbil da ação seja externo (uma inclinação ou uma coerção). A lei ética é a a lei que promana diretamente da vontade como

\footnotetext{
${ }^{43}$ A formulação é a mesma para o trecho que o filósofo se refere ao imperativo categórico, cf. MS, AA VI:225.
} 
legisladora e autora da sua legislação e seu caráter fortemente vinculante (o motivo para obedecer) é sua natureza autônoma.

\subsubsection{Unificando o imperativo categórico: autonomia e reino dos fins}

O imperativo categórico é o princípio supremo da moral ${ }^{44}$. Segundo a Metafísica dos Costumes, o imperativo categórico é expresso na Doutrina Universal dos Costumes ("Philosophia practica universalis") com os seguintes comentários:

O imperativo categórico, que em geral só enuncia uma obrigação, é: aja conforme a uma máxima que possa valer ao mesmo tempo como uma lei universal. - Você tem, portanto, de considerar suas ações primeiramente conforme ao princípio subjetivo dos mesmas. Que esse princípio seja também objetivamente válido, porém, você só pode reconhecer na medida em que, submetido por sua razão a essa prova por meio da qual você se pensa ao mesmo tempo como legislador universal, ele se qualifique a uma tal legislação (MS, AA VI:225).

Para chegar a essa formulação condensada, foi preciso definir a máxima como regra que o sujeito agente toma como o fundamento subjetivo de seu agir (portanto como seu princípio de ação) e definir a lei prática como o princípio que torna certas ações em dever. O imperativo categórico é, portanto, uma lei prática segundo a qual o sujeito prova sua máxima mediante a qualificação ou não ao status de lei prático-moral mediante o critério da universalidade.

Nos termos da Fundamentação da Metafísica dos Costumes, a questão recebe tratamento mais pormenorizado. Nessa obra, encontramos algumas formulações ${ }^{45}$ distintas que se remetem todas ao imperativo categórico. Devemos ter em mente, contudo, que o critério central para qualificar as ações morais nessa obra não é o par "ações conforme ao dever" (ações boas na medida

\footnotetext{
${ }^{44}$ Se procedermos à diferenciação que alguns autores procedem no sentido de separar o princípio supremo da moral, o princípio supremo da moralidade e o princípio supremo da doutrina dos costumes teremos de confessar alguns pontos. O primeiro deles é que o princípio supremo da moral e o princípio supremo da doutrina dos costumes são a mesma coisa, mas ambos diferem-se do princípio supremo da moralidade — que não haja apenas essa diferenciação (que só é possível à luz da Fundamentação da Metafísica dos Costumes), somos obrigados a concordar com Mary Gregor que Kant faz mesmo uma inversão (ou uma verdadeira confusão) de princípio na Fundamentação da Metafísica dos Costumes: o objetivo da obra, em suas próprias palavras, era "a busca e estabelecimento do princípio supremo da moralidade «obersten Princips der Moralität»" (GMS, AA IV:392), contudo o que verdadeiramente se fundamentou ali foi o princípio supremo comum da moral. Kant teria invertido a maneira de se referir aos dois princípios ou não considerava suficientemente claro, à época, que fossem dois princípios distintos. Cf. Mary Gregor apud TREVISAN, 2011, p. 258 (o comentário será transcrito palavra a palavra quando nos depararmos, mais adiante, com o problema da diferenciação dos princípios a título de solução para a segunda das questões incidentais do direito). ${ }^{45}$ Cf. PATON, Herbert James. The categorical imperative. Philadelphia: University of Pennsylvania Press, 1971, p. 129. Tomamos por base a distinção proposta por Paton que distingue três formulações distintas do imperativo categórico, sendo que duas formulações possuem tamanha proximidade em torno de um ponto em comum que as tornam apenas variantes de uma mesma formulação, conforme o esquema a seguir:

Ia. Fórmula da lei universal

Ib. Fórmula da lei universal da natureza

II. Fórmula da humanidade ou dos fins em si mesmos

IIIa. Fórmula da autonomia

IIIb. Fórmula do reino dos fins
} 
que concordam com o dever mas efetuadas sem necessariamente serem dotadas de motivação) e “ações por dever" (ações boas cuja motivação é o próprio dever e que vão contra a disposição natural do sujeito agente, que as realiza por meio de um juízo moral consciente). De maneira que:

Logo, nada resta para a vontade que possa determiná-la senão, objetivamente a lei e, subjetivamente, o puro respeito por essa lei prática, por conseguinte a máxima de dar cumprimento a uma tal lei mesmo com derrogação de todas as minhas inclinações (GMS, AA IV:399).

É interessante retomar a argumentação acerca das formulações do imperativo categórico à fim de chegarmos ao estabelecimento do princípio de autonomia da vontade e do conceito fecundo apenso a ele que é o reino dos fins. O princípio da autonomia da vontade pode ser encarado como a síntese de dois princípios anteriores expressos nas formulações do imperativo categórico da universalidade da lei e da dignidade inerente à natureza racional sempre como fim em si mesma (todos decorrentes do imperativo categórico).

A primeira formulação do imperativo categórico na Fundamentação da Metafísica dos Costumes é aquela formulação dita "canônica", pois mesmo após apresentar as várias formulações Kant reafirma tratar-se de um único e mesmo princípio que remete àquela formulação inicial:

Age apenas segundo a máxima pela qual possas ao mesmo tempo querer que ela se torne uma lei universal (GMS, AA IV:421).

Sua variação é a chamada fórmula da lei universal da natureza. As novidades da nova formulação com relação à formulação anterior, são os termos "como se" (que estabelece uma analogia) e a "lei da natureza" (com o que se estabelece a analogia). A ideia central é fazer uma analogia entre uma ação e sua lei segundo a perspectiva de dois domínios diferentes, tendo como fio condutor os efeitos da ação: certas causas, no domínio da natureza, geram necessariamente os mesmos efeitos, de maneira que é possível enunciar uma lei universal da natureza — propõe-se uma abstração similar no domínio da liberdade: se fosse possível pensar uma "necessidade" à semelhança da natural aqui, deveríamos adotar uma máxima que nos trouxesse sempre o efeito desejado como se fosse dotada da mesma necessidade de uma lei da natureza. Para John Raws ${ }^{46}$, que toma a formulação da natureza como a mais significativa de todas, estabelece-se o que ele chama de procedimento do imperativo categórico: "para que o imperativo categórico se aplique à nossa situação, precisa adaptar-se às nossas circunstâncias na ordem da natureza. Essa adaptação é realizada pelo procedimento do IC, na medida em que leva em conta as condições normais da vida humana por meio da formulação da lei da natureza".

O princípio da dignidade é alcançado na segunda formulação do imperativo categórico:

\footnotetext{
${ }^{46}$ RAWLS, John. História da filosofia moral. São Paulo: Martins Fontes, 2005, p. 193.
} 
Age de tal maneira que tomes a humanidade, tanto em tua pessoa, quanto na pessoa de outro, sempre ao mesmo tempo como fim, nunca meramente como meio (GMS, AA IV:429).

O princípio de autonomia da vontade, como dissemos, pode ser tomado como uma síntese dos dois princípios anteriores expressos cada um em uma das formulações do imperativo categórico: o princípio da universalidade como critério da moralidade e o princípio da humanidade como dignidade em si mesma. O princípio da autonomia da vontade nada mais é que a ideia de uma vontade universalmente legislante através de suas máximas, de tal forma que se reconheça como autora e súdita das leis que legisla universalmente:

Assim, o princípio de toda vontade humana, como uma vontade que legisla universalmente através de todas as suas máximas, conviria muito bem, desde que tudo o mais nele estivesse correto, a um imperativo categórico (GMS, AA IV:432).

Um conceito apenso e fecundo à ideia do princípio de autonomia da vontade é o de um reino de vontades autônomas, isto é, um reino dos fins. Uma pluralidade de dignidades em si mesmas tem de ser pensada da seguinte maneira: que esses seres estabeleçam relações entre si será necessário e, através do respeito mútuo em tratarem-se sempre também como fins em si mesmos e nunca meramente como meio, estabelece-se a legislação que liga esses seres uns aos outros de maneira vinculante. Poderíamos postular uma máxima, segundo a ideia do reino dos fins, como: "age como se fosse sempre, através de suas máximas, um membro legislador no reino universal dos fins" $"$.

Aproximando-nos de uma leitura rawlsiana, o conceito de reino dos fins é interessante visto que estabelece uma dinâmica social ao princípio da autonomia da vontade ao aplicá-lo às relações de uma pluralidade de dignidades e seus fins: é nesse conceito que se alcança uma determinação completa do imperativo categórico, reunindo a forma (o princípio de universalidade) e a única materialidade que convém à moral (o princípio da dignidade em si mesma da racionalidade).

A ideia de um reino dos fins convém sobremaneira a esta pesquisa na medida que buscaremos nos apoiar na noção de progresso tomada de empréstimo da filosofia da história: o direito é tido como condição facilitadora da moralidade, isto é, que ajuda na moralização de um povo. O fim da moralização seria alcançar um todo moral — seria o todo moral o reino dos fins (vez que todo dever jurídico é também um dever ético)? Se sim, a contínua moralização guiaria a utilizar-se cada vez menos do instituto da coerção, previsto na doutrina do direito, como medida de convencimento: as ações dos cidadãos guiar-se-iam cada vez mais ao agir por respeito ao dever, isto é, virtuosamente anteriormente mesmo à obrigação jurídica.

\footnotetext{
${ }^{47}$ Cf. GMS, AA IV:433-434.
} 


\subsubsection{A doutrina do direito}

O princípio da autonomia da vontade foi exposto na seção anterior; a autonomia jurídica, contudo, não pode ainda ser exposta neste capítulo: alcançá-la depende de um estudo mais aprofundado do direito político e especialmente da ideia de soberania - e essa tarefa compete ao capítulo vindouro. Por ora, esta seção tem como objetivo apresentar os principais pontos da doutrina do direito kantiana de maneira a abrir caminho para o direito político: cabe compreender a gênese e algumas especificidades da doutrina kantiana dos costumes, de maneira a esclarecer a natureza da doutrina do direito e demarcar claramente sua posição frente aos novos desenvolvimentos contemporâneos (esta é a função das questões incidentais aqui apresentadas).

Primeiramente, é preciso efetuar uma distinção básica no sistema dos costumes: o direito tem a ver unicamente com a relação entre arbítrios, abstraído dos motivos que conduzem à ação; a ética tem a ver com o trabalho da vontade, isto é, com os motivos que subjazem às ações. Desta maneira, a legislação ética concerne menos às ações (pois esse é o escopo da legislação jurídica), mas apenas para as máximas que norteiam as ações ${ }^{48}$. O direito não tem a ver, portanto, com o comando ético universal: “aja em conformidade com o dever por dever” (MS, AA IV:391); fundar e avivar em si essa intenção é meritório, mas não é juridicamente exigível.

A diferença fundamental entre o direito e a ética pode ser assim descrita:

A doutrina do direito tinha a ver apenas com a condição formal da liberdade externa (por meio da concordância consigo mesma, quando sua máxima se convertia em lei universal), isto é, com o direito. A ética, pelo contrário, proporciona ainda uma matéria (um objeto do livre-arbítrio), um fim da razão pura que é representado ao mesmo tempo como um fim objetivamente necessário, isto é, como um dever para o ser humano (MS, VI:380).

Se as leis procedem da vontade e as máximas procedem do arbítrio ${ }^{49}$, então o princípio de autonomia pertence à vontade e, como foi referido anteriormente, o conceito de autonomia está intimamente ligado ao conceito de legislação — da capacidade da vontade ser para si mesma uma lei. Cabe estudar como e por que razão foi possível o surgimento de leis que regulem a liberdade externa, isto é, uma legislação jurídica.

A Introdução da Doutrina do Direito é dividida inicialmente em cinco seções a partir dos quais depreendemos cinco pontos básicos da teoria kantiana: que $(\S A)$ a presente doutrina do direito refere-se a uma doutrina do direito natural; que $(\S B)$ à presente doutrina do direito concerne o problema do justo e do injusto, apresentando-se um conceito de direito ligado à moral; que ( $\$ C$ ) assim sendo, apresenta-se o princípio universal que baliza o conceito de direito apresentado; que $(\S D)$ a coerção deve ser pensada como legítima em vista do conceito moral de direito, visto que

\footnotetext{
${ }^{48}$ Cf. MS, AA VI:388.

${ }^{49}$ Cf. MS, AA VI:226.
} 
garante o princípio universal do direito; finalmente $(\S E)$, a justificação do porquê a coerção é legítima em vista do direito estrito - aquele não mesclado a elementos da virtude. Por fim, estabelece o direito inato de todos os homens em virtude de sua humanidade (a liberdade).

Na primeira seção, Kant estabelece uma diferenciação indireta entre a doutrina do direito e o conceito de direito, mas a centralidade da seção é a determinação precisa do que se refere a doutrina do direito. Assim, diz Kant, "chama-se doutrina do direito o conjunto de leis para as quais é possível uma legislação externa” (MS, AA VI:229). Se tal legislação tem efetividade empírica é o chamado direito positivo; contudo, lembremo-nos que a doutrina do direito kantiano é uma metafísica e, portanto, uma teoria erigida a partir de princípios a priori, isto é, um conjunto de princípios universais abstraídos de elementos empíricos mínimos, mas tal teoria não possui positivação efetiva. A presente doutrina do direito é uma doutrina do direito natural; um direito natural cuja gênese nada mais é que a própria razão - nesse sentido, a expressão direito natural «Naturrecht» liga-se à tradição do direito natural por seu humanismo e (do ponto de vista político) a preocupação de estabelecer uma legislação que ofereça limites ao poder estabelecido. Cabe destacar, contudo, que a doutrina do direito natural pode ser descrita também como uma doutrina do direito racional dado que toda sua justificação repousa em princípios racionais, o que legitima francamente a doutrina do direito kantiana frente às outras doutrinas jusnaturalistas — veremos adiante que, relativamente a esse caráter racionalista, Kant é fortemente devedor da doutrina jusnaturalista de outro jurista alemão, a saber, Samuel von Pufendorf.

Goyard-Fabre faz um apontamento esclarecedor que acentua claramente a diferença da doutrina kantiana frente à tradição jusnaturalista anterior: ao contrário da tradição do direito natural de até então, Kant não tem a pretensão de fundar o direito positivo sobre a autoridade do direito natural; antes, interessa-lhe que o direito positivo existente possa ser comparado àqueles princípios metafísicos do direito natural ${ }^{50}$.

A argumentação kantiana da seção segue caminhos mais tortuosos: baseia-se nas habilidades daquele que lida com o direito para abstrair daí a diferença entre o direito positivo e o direito natural. Aquele jurista teórico que é versado no direito positivo é o jurisconsulto, ao passo que o jurista prático (aquele que sabe aplicar as leis positivas aos casos que se apresentam no empírico) é o perito em direito - essa capacidade é a jurisprudência. Tanto o jurisconsulto quanto o perito em direito têm o conhecimento técnico do direito. Aquele jurista, contudo, que tem o conhecimento sistemático do direito alcança a ciência do direito: conhece os princípios imutáveis para toda legislação positiva possível, isto é, conhece os princípios do direito natural. A doutrina do direito kantiana refere-se, portanto, àquela legislação imutável dos princípios do direito natural.

\footnotetext{
${ }^{50}$ Cf. Goyard-Fabre, Simone. Kant et le problème du droit. Paris: Vrin, 1978, p. 128.
} 
O direito natural pode ser resumido em quatro proposições: primeiramente, é constituído de princípios a priori e não necessita de efetividade empírica; em segundo lugar, sua fonte é a razão pura e não a vontade do legislador; em terceiro lugar, ao direito natural concerne a questão da justiça e não a questão "o que é de direito" (o escopo desta questão é meramente técnico); por fim, o direito natural são os princípios imutáveis que devem balizar todo o direito estatutário possível para fins da legitimidade da legislação positiva ${ }^{51}$.

Falta determinar o conceito de direito: a doutrina do direito refere-se sempre a um conceito moral do direito, àquele direito que corresponda uma obrigação na medida que na relação externa das ações de uma pessoa à outra se gere influência ou impacto de uma pessoa à outra; desta sorte, o direito não tem por objeto a relação do arbítrio de um com o desejo do outro, mas única e simplesmente a relação de um arbítrio com o arbítrio de outrem ${ }^{52}$. Noutras palavras, o direito preocupa-se em regular as ações e sua conformidade, não a intenção (portanto não a materialidade do agir, isto é, os fins).

O conceito do direito é enunciado assim:

O direito, portanto, é o conjunto das condições sob as quais o arbítrio de um pode conciliar-se com o arbítrio de outro segundo uma lei universal da liberdade (MS, AA $\mathrm{VI}: 230)$.

E o princípio que subjaz a esse conceito deve ser:

É correta toda ação que permite, ou cuja máxima permite, a liberdade do arbítrio de cada um coexistir com a liberdade de todos segundo uma lei universal etc (MS, AA VI:230).

É incorreta e, portanto, um obstáculo ao direito toda pretensão ou ação que atente à liberdade segundo leis universais; assim, deve ser lícita somente aquela resistência a uma ação que vise garantir a liberdade de todos. Essa resistência lícita é a coerção própria do direito: um impedimento de um obstáculo à liberdade ou potência de agir para garantir a liberdade segundo leis universais. O direito estrito, ou seja, aquela legislação externa que se refira somente à relação entre arbítrios "pode ser representado também como a possibilidade de uma coerção recíproca universal em concordância com a liberdade de cada um segundo leis universais" (MS, AA VI:232).

O ponto de determinação da doutrina do direito kantiana é a propriedade: a partir dessa constatação abre-se dois caminhos de reflexão sobre o direito kantiano e cabe explorá-los agora. Pelo primeiro caminho, Goyard-Fabre ${ }^{53}$ distingue finamente a justificação da propriedade em Kant e em sistemas clássicos da filosofia política tais como em Locke ou em Harrington: com efeito, o caráter liberal da doutrina do direito e a forte defesa da propriedade privada tornaria inegável a

\footnotetext{
${ }^{51}$ Cf. Nour, 2004, p. 7.

${ }^{52}$ Cf. MS, AA VI: 230.

${ }^{53}$ Cf. Goyard-Fabre, op. cit., p. 124-126.
} 
maior aproximação de Kant à doutrina de John Locke e outros autores liberais. Segundo a autora, à noção de posse e do direito à propriedade ainda estava ligada uma visão de direito sagrado do indivíduo na filosofia política clássica; por outro lado, em Kant a posse e a propriedade decorrem de um postulado próprio da razão prática. Mais uma vez, havemos com a especificidade própria do direito kantiano: uma metafísica no sentido de erigir-se sobre princípios a priori, isto é, um embasamento interno que não recorre a outra autoridade senão a própria razão — assim, a propriedade não é sagrada senão decorrente do uso natural da razão aos objetos exteriores. O postulado da razão prática, recordemos, é este:

É possível ter como meu qualquer objeto exterior de meu arbítrio. Ou seja: é contrária ao direito uma máxima tal que, se ela se tornasse lei, um objeto do arbítrio teria de ser, em si (objetivamente), sem dono (res nullius) (MS, AA VI:246 - grifos nossos).

A esse importante pormenor, da fundamentação do direito repousar em bases puramente racionais, podemos adentrar em duas considerações aparentemente desconexas entre si: a principal delas é uma consideração de Habermas ${ }^{54}$, que imputa a Hobbes uma petição de princípio dos indivíduos descritos por eles serem incapazes de uma noção de reciprocidade que motivasse o pacto originário ${ }^{55}$; a outra é de Philonenko ${ }^{56}$, que explora a dívida confessa de Kant para com Rousseau e conclui que a doutrina do direito kantiana é muito mais devedora daquela doutrina de Pufendorf — pois a fundamentação da doutrina jusnaturalista deste repousava no reconhecimento comum de uma certa racionalidade, isto é, de certos princípios que não podiam ser negados sem que se incorresse em contradição. A resolução do problema que Habermas imputa a Hobbes depende em grande medida de conceitos do direito político, especialmente a ideia política de soberania, razão pela qual o problema é apontado aqui, mas somente resolvido no capítulo vindouro. Por ora, objetivamos chamar a atenção para o ponto de origem das relações jurídicas em Kant ser puramente racional: o postulado jurídico da razão prática.

É mediante o artefato do contrato social é que se adentra em um estado civil e, portanto, ao legitimar o direito público legitima também a passagem de uma posse real a possibilidade uma posse inteligível, uma posse de caráter inicialmente temporário no direito privado à posso de caráter peremptório ${ }^{57}$. O contrato social como "fonte pura do direito" resulta no justo e no injusto manterem, ao cabo, uma tensão dialética sempre presente - por um lado, a fundamentação mais básica do direito é a razão, isto é, os princípios racionais a priori, imutáveis e dotados de universalidade; tais princípios, pela ideia mesma do contrato social pelo qual recebem sua

\footnotetext{
${ }^{54}$ HABERMAS, J. Direito e democracia: entre factibilidade e validade. Rio de Janeiro, 1997, pp. 122/128.

${ }^{55}$ Sobre este ponto, mais será tratado no capítulo seguinte quando abordarmos a questão da passagem do estado de natureza ao estado civil-jurídico.

${ }^{56}$ PHILONENKO, Alexis. "Souveranité et legitimité chez Kant et Fichte". In: Études kantiennes. Paris: Vrin, 1982, pp. 91-96.

${ }^{57}$ Cf. PERES, Daniel Tourinho. Kant: metafísica e política. Salvador: EDUFBA/UNESP, 2004, pp. 75-88.
} 
materialidade empírica, apontam para uma teoria linguística (a um acordo ou pacto) que determine o justo e injusto. É o caráter de público no sentido de "aberto" «öffentliche» do pacto social que institui o direito público que também determina a justiça ou injustiça relativa, por exemplo, a uma nova modalidade de posse - a posse jurídica.

Essa tensão entre o "fechado" imutável da razão pura e o "aberto" do público que possibilita a pergunta pela legitimidade do direito: a reflexão sobre as fontes da legitimidade do direito emerge naturalmente neste ponto porque pretendemos trabalhar com a noção de autonomia articulada à legitimidade da lei jurídica. Trata-se de reconhecer a diferenciação entre os conceitos de legitimidade e legalidade quando aplicados à norma jurídica; noutras palavras, se seria o caso da legitimidade dessa norma repousar em um fator externo ou se a própria norma jurídica bastaria em si mesma para fundamentar-se. Vimos que a doutrina do direito kantiana refere-se à doutrina do direito natural e, portanto, preocupa-se centralmente com a questão "o que é justo ou injusto": Höffe observa que a doutrina kantiana mira não somente ao direito positivo mas também às teorias do direito positivo que não se preocupam com a questão do justo e do injusto — aquelas teorias que se encerram na regulamentação interna do direito, tais como a teoria pura do direito de Kelsen e a aplicação da teoria dos sistemas autopoiéticos ao direito proposta por Luhmann. Duas questões precisas serão abordadas aqui em razão de, à primeira vista, oporem-se à leitura que até então associamos ao pensamento kantiano e, mesmo assim, ambas se autodeclaram filiadas ao kantismo: de um lado, a teoria pura do direito de Kelsen e, de outro lado, a controvérsia na literatura kantiana de comentadores que advoga uma tese de independência do direito pelo motivo de não ser possível extrair do imperativo categórico todos os deveres jurídicos e, daí, o não pertencimento do direito à moral. Nos dois casos, advoga-se algum grau de auto-regulamentação do direito à primeira vista.

\subsubsection{Questão incidental: o positivismo jurídico de Kelsen}

O que se pretende mostrar brevemente nesta seção é pontuar claramente que há distinções entre os objetivos da Doutrina do Direito de Kant e a Teoria Pura do Direito de Kelsen. No século XX, a teoria pura do direito de Kelsen e a teoria do agir comunicativo de Habermas estiveram em postos diferentes e contrários; ambas ligadas, de alguma maneira, à recepção do pensamento kantiano. Contudo, vez que essas distinções sejam tomadas em consideração, invalida-se de pronto uma oposição entre as teorias de Kelsen e Kant: os objetivos que cada uma se pretende é diferente relativamente à outra e qualquer oposição só pode surgir da confusão de acreditar que ambas as teorias visem a um mesmo fim.

A frase de abertura do livro Teoria Pura do Direito dá ideia do escopo pretendido por Kelsen: "a Teoria Pura do Direito é uma teoria do direito positivo". Primeiramente, como 
esperamos haver deixado suficientemente enfatizado, a Doutrina do Direito de Kant é uma teoria metafísica que se apoia em juízos apriorísticos a fim de remontar a uma ideia de direito: não pretende ser uma teoria para o direito positivo nem nasce do direito positivo; a teoria de Kelsen, por outro lado, debruça-se na produção de normas ${ }^{58}$ pelo homem e na produção do direito pela autoridade competente ${ }^{59}$. Kelsen prossegue: "como teoria, quer única e exclusivamente conhecer o seu próprio objeto. Procura responder a esta questão: o que é e como é o direito? Mas já não lhe importa a questão de saber como deve ser o direito, ou como deve ele ser feito"60. Esses são pontos de grande contraste entre os objetivos dos dois autores: Kelsen afasta-se da noção da teoria do direito como ideia reguladora; e, em Kant, encontramos a noção metafísica do Direito Natural «Naturrecht».

O ponto nevrálgico de distinção entre as duas teorias diz razão à distinção entre a busca pelo valor do direito e a busca pela validade do direito: noutras palavras, o problema da norma ser justa e o problema da norma ser válida ${ }^{61}$. $\mathrm{O}$ valor do direito diz respeito à questão da justiça, é uma questão filosófica por excelência; a validade da norma nada tem a ver com a questão da justiça senão, unicamente, com a pergunta "o que é de direito?” — isto é, limita-se na consideração pelos atos que estão em consonância técnica com a norma positivada. Não importa, para a teoria pura, a justiça ou injustiça da norma como critério de sua validade: frente às teorias da justiça, a teoria pura do direito é indiferente. Vê-se, pois, que os objetivos não-coincidentes determinam um afastamento linearmente contínuo.

A teoria pura responde especificamente a duas tradições históricas em sentido contrário: a tradição do jus naturalismo (que fornece valores fundamentais a fim de avaliar a legitimidade do direito positivo) e a tradição sociológica (que tenta introjetar valores sociais ou ideologias temporais e contingenciais ao direito como parâmetro de justiça). É verdade que haja, em Kant, um direito natural «Naturrecht», contudo o direito natural kantiano difere-se da tradição jus naturalista por não ser um conjunto de valores políticos temporais fechados.

\footnotetext{
${ }^{58}$ KELSEN, 1999, p. 4: "com o termo 'norma' se quer significar que algo deve ser ou acontecer, especialmente que um homem se deve conduzir de determinada maneira". A normatização aponta, portanto, para os costumes de maneira geral: tanto uma norma instituída mas não positivada (ética) quanto para a norma legislada e instituída pelo poder. ${ }^{59}$ Cf. KELSEN, 1999, p. 52: "Também é verdade que, no sentido da teoria do conhecimento de Kant, a ciência jurídica como conhecimento do Direito, assim como todo o conhecimento, tem caráter constitutivo e, por conseguinte, 'produz' o seu objeto na medida em que o apreende como um todo com sentido. Assim como o caos das sensações só através do conhecimento ordenador da ciência se transforma em cosmos, isto é, em natureza como um sistema unitário, assim também a pluralidade das normas jurídicas gerais e individuais postas pelos órgãos jurídicos, isto é, o material dado à ciência do Direito, só através do conhecimento da ciência jurídica se transforma num sistema unitário isento de contradições, ou seja, numa ordem jurídica. Esta 'produção', porém, tem um puro caráter teorético ou gnoseológico. Ela é algo completamente diferente da produção de objetos pelo trabalho humano ou da produção do Direito pela autoridade jurídica".

${ }^{60}$ KELSEN, 1999, p. 1.

${ }^{61}$ Cf. BOBBIO, N. Direito e poder. São Paulo: UNESP, 2008, p. 25.
} 
Para Kant, conforme vimos, o direito é metafísico e parte constitutiva da moral por estar subordinado ao imperativo categórico — o problema com o qual o filósofo está preocupado é a ideia de Direito e isso tem duas implicações: em um primeiro momento, é essencialmente metafísico e difere-se da teoria pura do direito nesse aspecto; em um segundo momento, a Doutrina do Direito, caracterizada como uma ideia do direito, exerce função reguladora.

Os empreendimentos de ambos os autores se cruzam em certa medida:

Assim como Kant pergunta: como é possível uma interpretação, alheia a toda metafísica, dos fatos dados aos nossos sentidos nas leis naturais formuladas pela ciência da natureza, a Teoria Pura do Direito pergunta: como é possível uma interpretação, não reconduzível a autoridades metajurídicas, como Deus ou a natureza, do sentido subjetivo de certos fatos como um sistema de normas jurídicas objetivamente válidas descritíveis em proposições jurídicas ${ }^{62}$

No entanto, Kelsen tem de afastar o dever jurídico de qualquer vínculo com o dever moral ${ }^{63}$ para ser consequente com o que se propõe em sua teoria: que o escopo bastante restrito de sua teoria pura centre-se na validade da norma legislada e instituída. Não lhe interessa a justificação do poder (como faz Kant) nem lhe cabe uma ideia de progresso pelo direito - a teoria pura do direito nada tem a ver com a política ou a politização do direito, diz Kelsen; portanto, não se encontra o problema da teoria e da prática do direito nos termos em que se encontra em Kant e, assim, remanesce o problema do direito se encerrar em sua própria auto-regulamentação sem questionar-se reflexivamente sobre a justiça.

\subsubsection{Questão incidental: a tese da independência do direito}

A chamada "tese da independência do direito" não tem a mesma solução que apresentamos no caso da teoria pura do direito: neste caso toda a problemática é interna à doutrina kantiana e o ponto sensível da questão se assenta em uma discordância interpretativa, a saber, que não se

\footnotetext{
62 Cf. KELSEN, 1999, p. 141.

${ }^{63}$ Cf. KELSEN, 1999, pp. 82-83: A palavra “dever" ("Pflicht”) está ligada na língua alemã - especialmente depois da Ética de Kant - a idéia de um valor moral absoluto. O princípio segundo o qual o homem deve cumprir sempre o seu "dever" ou os seus "deveres" pressupõe evidentemente que haja deveres absolutos, inteligíveis para todos. De outro modo, isto é, se se admitisse que não há uma moral absoluta, mas várias e muito diversas ordens morais que prescrevem condutas que se contrariam, o princípio citado, que constitui o princípio fundamental da ética kantiana, reconduzir-se-ia à tautologia de que o homem deve sempre fazer aquilo que, de conformidade com a ordem moral tomada em consideração, é prescrito, ou seja: que ele deve fazer o que deve fazer. O conceito de dever jurídico referese exclusivamente a uma ordem jurídica positiva e não tem qualquer espécie de implicação moral. Um dever jurídico pode - embora isso se não 83 verifique necessariamente - ter como conteúdo a mesma conduta que é prescrita em qualquer sistema moral, mas também pode ter por conteúdo a conduta oposta, por forma a existir - como costuma admitir-se em tal hipótese - um conflito entre dever jurídico e dever moral. Para evitar a possibilidade de um tal conflito foi mesmo afirmado que o dever em geral não é um conceito jurídico, que apenas a Moral, e não o Direito, obriga, que a função específica do Direito - diferentemente da Moral - é conferir direitos. Se, contudo, se reconhece que ser obrigado a uma conduta não significa senão que esta conduta é prescrita por uma norma - e não pode negarse que a ordem jurídica (como toda ordem normativa) prescreve uma determinada conduta humana - então obrigar (constituir na obrigação de) tem de considerar-se uma função essencial do Direito e, como se mostra pela análise que faremos em seguida da função do conferir-direitos, tem mesmo de se reconhecer que tal função ocupa um lugar de primazia em relação a esta última.
} 
poderia derivar todos os deveres jurídicos do princípio supremo da moralidade e isso gera uma tensão no interior da doutrina dos costumes nos termos da filosofia kantiana. À primeira vista, parece ser o caso de uma defesa de uma branda auto-regulamentação do direito. Tomamos como estudo de caso os argumentos de Wood $^{64}$ sobre o assunto.

Wood oferece inicialmente uma lista de pontos conflitantes para questionar que o princípio supremo da moralidade seja base comum para derivar os deveres jurídicos e os deveres da virtude. Argumenta que Kant fala explicitamente que o conceito de direito se deriva do imperativo categórico, mas que ele não diz de maneira explicita que o princípio universal do direito também se derive do imperativo categórico. Argumenta também que a declaração que "o princípio supremo da doutrina do direito era analítico; o da doutrina da virtude é sintético" (MS, AA VI:396) aponta definitivamente que o direito é apartado da moral em razão da analiticidade de seu princípio. $\mathrm{O}$ cerne de seu argumento, contudo, é este:

De certo, o direito (Recht) junto com a ética (Ethik), no contexto da Metafísica dos
Costumes, ambos pertencem à filosofia prática ou 'costumes' (Sitten). Ambas as partes
envolvem imperativos categóricos porque Kant sustenta que os deveres jurídicos são
também deveres éticos (MS 6:219). Na medida que deveres jurídicos são considerados
como deveres éticos, podem ser conduzidos sob o princípio da ética, que pode ser usado
também para mostrar que temos boas razões para valorizar a liberdade externa (ou o
direito) e respeitar as instituições que protegem o correto através de coações externas.
Dessa maneira, pode ser correto dizer que a teoria do direito kantiano repousa ou pode
ser derivada do princípio da moralidade. Isto é, isso pode ser afirmado na medida em que
os deveres jurídicos podem ser considerados não meramente como deveres jurídicos mas
também como éticos. Considerados simplesmente como deveres jurídicos, contudo,
pertencem a um ramo da metafísica dos costumes que é inteiramente independente da
ética e também do seu princípio supremo

A questão precisa ser reposta, passo a passo, à luz desses esclarecimentos. Wood distingue, tal como fizemos, moral «Moral» de ética «Ethik»; segue à letra da Metafísica dos Costumes ao associar os deveres jurídicos, em última instância, como éticos também. O ponto preciso da questão desvela-se: os deveres jurídicos, tomados apenas do ponto de deveres jurídicos, são independentes da ética e de seu princípio supremo — mas o que vem a ser propriamente o princípio supremo da ética? Uma série de comentadores distingue entre um "princípio supremo da moral” e "um princípio supremo da moralidade" ${ }^{66}$, fazendo alusão a um peso excessivamente ético presente na Fundamentação da Metafísica dos Costumes (que sufocava o direito) e que viria a ser corrigido

\footnotetext{
${ }^{64}$ Cf. WOOD, 2004, pp. 1-21. Como contraponto utilizaremos o comentário em que Guyer responde precisamente a esse tópico da argumentação de Wood (cf. GUYER, Paul. "Kant's deductions of the principles of Right". In: TIMMONS, op. cit., pp. 23-64).

${ }^{65}$ WOOD, 2004, p. 9.

${ }^{66}$ Mary Gregor (apud TREVISAN, 2011, p. 258) faz um comentário que lança luzes à questão: “O princípio que ele [Kant] queria estabelecer deveria ter sido tanto o princípio supremo da moral — do qual todos os deveres são derivados — quanto o princípio supremo da moralidade — o qual guia o agente quando o cumprimento de seu dever é uma ação moralmente boa. Contudo, Kant ocupou-se dele [na Fundamentação da Metafísica dos Costumes] especialmente como princípio supremo da moralidade".
} 
na Metafísica dos Costumes. Qual seria então o alegado princípio supremo da ética (princípio supremo da moralidade) — aquilo que na Metafísica dos Costumes (MS, AA VI:391) é descrito como comando ético universal: "aja em conformidade com o dever por dever”? Se esse for o caso, não há problemas com a abordagem de Wood: de fato o par "agir conforme ao dever" e "agir por dever" é apropriadamente mudado pela distinção entre "legalidade" e "moralidade". Ou talvez deveríamos ler o princípio supremo da moralidade como referindo-se ao princípio de autonomia da vontade tal como estabelece a Fundamentação da Metafísica dos Costumes (GMS, AA IV:440) e reforçado pela leitura que alguns comentadores procedem de que o arbítrio é ligado ao direito e a vontade à ética? Parece ser este o caminho mais consequente.

O problema se sustenta se, diferentemente do nosso entendimento interpretativo de conceder aceitar a proposta de ressignificação de termos pelo texto, o leitor dos comentários insistir em não distinguir o "princípio supremo da moral" do "princípio supremo da moralidade" no contexto da argumentação de Wood ${ }^{67}$. Assim, aparenta que Wood sustenta uma total independência do direito frente à moral em sentido amplo, isto é, uma completa desvinculação do direito à doutrina metafísica dos costumes - algo que aproximaria a leitura de Wood àquela proposta por Kelsen ${ }^{68}$. Não é o caso: o princípio que Wood prega é no sentido de independência do direito à ética, não de independência dos costumes.

A plausibilidade em favor da nossa leitura (ancorada no entendimento de alguns comentadores que pregam um peso excessivamente ético na Fundamentação), nota-se no seguinte comentário:

Abordagens kantianas dos direitos individuais e outros tópicos relativos ao direito natural,
lei e autoridade política, têm frequentemente sido inspirados pelas formulações do
princípio da moralidade a partir da Fundamentação. Quaisquer que sejam os méritos
filosóficos dessas considerações, tais interpretações divergem necessariamente do

67 Princípio supremo da moral ou princípio supremo da moralidade: não fazemos distinção entre ambas as nomenclaturas. Nossa interpretação é que ambas as expressões remetem ao imperativo categórico ou, o que seria o mesmo, ao princípio supremo da doutrina dos costumes — que são os mesmos e preconizam agir segundo uma máxima que possa valer universalmente como lei. Reconhecemos o problema de interpretação proposto por Wood (que diz respeito ao caráter excessivamente ético da Fundamentação da Metafísica dos Costumes e que é reconfigurado, mais tarde por Kant, à luz de uma habilitação incisiva do direito na Introdução comum a ambas as partes da Metafísica dos Costumes) e, no espírito de compreensão do problema que Wood traz, é que concedemos trabalhar temporariamente nesta subseção com o princípio supremo da moralidade entendido como o comando ético universal.

${ }^{68}$ Cabe notar que outro autor faz a defesa da tese que não se pode derivar os deveres jurídicos do imperativo categórico: Marcus Willaschek. Segundo sua leitura, pode-se conceder que o conceito de direito (“o direito, portanto, é o conjunto das condições sobre as quais o arbítrio de um pode conciliar-se com o arbítrio de outro segundo uma lei universal da liberdade" (MS, AA VI:230) derive-se do imperativo categórico; contudo, é duvidoso que o princípio universal do direito (“é correta toda ação que permite, ou cuja máxima permite, à liberdade do arbítrio de cada um coexistir com a liberdade de todos segundo uma lei universal" — MS, AA VI:230) ou a lei universal do direito ("aja externamente de tal modo que o uso livre do seu arbítrio possa coexistir com a liberdade de cada um segundo uma lei universal" MS, AA VI:231). Cf. WILLASCHEK, Marcus. "Porque a doutrina do direito não pertence à metafísica dos costumes: algumas distinções básicas na filosofia moral de Kant”. In: TRAVESSONI, Alexandre. (org.) Kant e o Direito. Belo Horizonte: Mandamentos, 2009, pp. 257-292; WILLASCHEK, Marcus. "Which imperatives for Right? On the nonprescriptive character of juridical laws in Kant's Metaphysics of Morals". In: TIMMONS, op. cit., pp. 65-87. 
tratamento mesmo de Kant para tais tópicos, simplesmente porque o território coberto pela Doutrina do Direito necessariamente fica inteiramente fora daquele mapeado pela Fundamentação e pela segunda Crítica $^{69}$.

Ainda segundo Wood, tais abordagens do direito podem também infectar o entendimento apropriado da ética kantiana, em seu entender, porque mesclam pressupostos "não-kantianos" sobre a moralidade. Noutro trecho, afirma que a conformidade ao direito pode ser impulsionada por "motivações não-kantianas" (interesse egoístico, obediência a uma vontade divina, a busca pela paz de uma maneira hobbesiana etc $^{70}$ ). Caberia distinguir o que se aponta com os adjetivos "kantiano" e "não-kantiano", isto é, em qual das obras sobre a moral está o purismo a que o adjetivo "kantiano" faz referência.

\subsection{A coesão do sistema: relações entre a política e a filosofia da história}

Trata-se aqui de abordar a difícil articulação interna entre os textos de filosofia do direito, política e história. Como vimos anteriormente, quando estudados isoladamente pode-se chegar a posicionamentos interpretativos bastante distintos. Essa dificuldade decorre e aponta para o âmbito da razão ser orientada arquitetonicamente ${ }^{71}$.

$\mathrm{O}$ esforço arquitetônico tem a ver com o método e isso fica claro à medida que nos aprofundamos analiticamente nas definições de sistema e todo: por sistema deve-se compreender a unidade dos conhecimentos diversos organizados sob uma ideia - precisamente, essa ideia a que se refere é um conceito puro que expressa a forma de um todo. Esse todo deve ser compreendido como: (1) um articulado e não um mero amontoado; e (2) que cresce internamente - mas não externamente por aposição. Assim, cada campo do saber cresce internamente no sentido de ter uma articulação interna própria sem a preocupação da articulação exterior: daí advêm as constantes tensões da filosofia kantiana. Cabe salientar que essa também é a dinâmica do sistema dos costumes. Necessita-se, para formar o sistema, de um procedimento específico que possibilite criar pontes entre seus diversos campos e os conhecimentos adquiridos internamente: segundo Ricardo Terra, esse procedimento é o de construir passagens «Übergange» entre os elementos do sistema ${ }^{72}$. O conceito de passagem não é unívoco, havendo vários sentidos e usos a depender das obras e seus respectivos contextos; contudo, pode-se reconhecer um papel em

\footnotetext{
${ }^{69}$ WOOD, 2004, p. 9.

${ }^{70}$ Ironicamente, Wood termina sua análise entre direito e ética afirmando que a vantagem do direito kantiano é poder ser aplicado perfeitamente para sociedades não-kantianas.

${ }^{71}$ Nesse sentido, diz Kant que "a razão humana é arquitetônica segundo sua natureza, i.e., ela considera todos os conhecimentos como pertencentes a um sistema possível e só admite, pois, aqueles princípios que ao menos não tornem impossível conciliar um conhecimento excelente com outros em um sistema" (KrV, B502).

${ }^{72}$ Cf. TERRA, Ricardo. "Sentidos de 'passagem' (Übergang)". In: Passagens: estudos sobre a filosofia de Kant. Rio de Janeiro: Editora da UFRJ, 2003, pp. 51-65.
} 
comum nas diversas acepções do termo, a saber, de servir de transição, quer entre estágios do pensamento kantiano, quer entre domínios bastante distintos: a passagem mantém ativos os dois pontos de vista conflitantes sem anular nenhum deles, apenas procede à mudança no ponto de abordagem. Novamente, podemos reafirmar que a filosofia política ganha um papel de relevo no campo prático da razão por sua própria natureza multidisciplinar ${ }^{73}$ : o texto d'À paz perpétua tem um caráter arquitetônico e, por conta disso, pode-se tomar suas partes como um emaranhado de passagens.

Ademais, um comentário de Eric Weil mostra-se bastante oportuno para nossa análise por chamar a atenção para a importância do pensamento kantiano na história do pensamento moderno, porque Kant

formulou as questões sobre o sentido da história e da política para o homem, em lugar daquelas perguntas sobre a melhor técnica política e sobre as 'leis históricas'. A política cessa, com Kant, de ser uma preocupação para os filósofos; torna-se, ao mesmo tempo que a história, problema filosófico, agindo na - e sobre a - totalidade do pensamento: não se trata mais de fazer um arranjo entre história e política, trata-se de compreender seu sentido comum, o sentido que deve decidir sobre qualquer arranjo ${ }^{74}$.

Destarte, é com Kant que a reflexão filosófica moderna sobre a política e a história tem seu eixo reposicionado de maneira inovadora, pois é a partir de Kant que a pergunta que se faz a esses campos do saber não é apenas pela melhor técnica, isto é, pela busca da melhor ferramenta conceitual quanto à possibilidade de aplicabilidade, mas também sobre o sentido mesmo da política e da história para os homens. Essa mudança de escopo muda também o método: a abordagem se dará desde seu princípio orientada em função de uma ideia ou, para usar um termo caro à filosofia kantiana, orientada por um fio condutor a priori ${ }^{75}$.

Leonel Ribeiro defende que também se considera arquitetônica aquela ciência ou arte que tem a função de

conjungar, em vista de um fim soberano, considerado como um bem comum, todas as outras ciências e artes, a título de meios. É neste sentido que a Política pode ser considerada ciência arquitetônica; não, portanto, porque seja em si mesma suprema, mas devido a sua função de mediação e por lhe caber a apreciação concreta do que é adequado e do que é bem ou fim do todo, tendo em vista a realização destes ${ }^{76}$.

As leituras que se fazem centradas unicamente em uma parte específica da filosofia kantiana deixam de se ater aos seguintes pontos: primeiramente, ao caráter arquitetônico da razão;

\footnotetext{
${ }^{73}$ Cf. "Sobre a arquitetônica da razão prática". In: TERRA, 2003, pp. 81-82.

${ }^{74}$ WEIL, 1970:140-141 — tradução própria.

${ }^{75}$ Essa nova abordagem aparece clara nos comentários finais do filósofo sobre sua proposta de história quando afirma que "seria uma incompreensão do meu propósito considerar que, com esta ideia de uma história do mundo «Weltgeschichte», que de certo modo tem um fio condutor a priori, eu quisesse excluir a elaboração da história «Historie» propriamente dita" (IaG, AA VIII:30). Cf. a mesma noção em ZINGANO, Marco Antonio. Razão e história em Kant. São Paulo: Editora Brasiliense, 1989, p.259.

${ }^{76}$ SANTOS, 1995, pp. 378-380 - grifo nosso.
} 
em segundo lugar, ao fato que, pelo direito, Kant busca sempre consolidar algo fornecendo a essa pretensão uma fundamentação racional ${ }^{77}$ (no caso em tela, consolidar os ganhos tangíveis obtidos até então pelo mecanismo da natureza) e não trazer algo com caráter de novidade; em terceiro lugar, que toda a construção jurídica do Estado está ligada à noção de progresso $^{78}$.

A noção de gênero ou espécie é importante porque é apenso à ela que vem a ideia de progresso $^{79}$. Diz Kant que:

no homem (única criatura racional sobre a Terra) aquelas disposições naturais que estão voltadas para o uso de sua razão devem desenvolver-se completamente apenas na espécie e não no indivíduo (IaG, VIII:18).

A tensão da nossa investigação ganha corpo a partir da oitava proposição da Ideia universal de um ponto de vista cosmopolita. Seu enunciado diz que

pode-se considerar a história da espécie humana, em seu conjunto, como a realização de um plano oculto da natureza para estabelecer uma constituição política perfeita interiormente e, quanto a este fim, também exteriormente perfeita, como o único estado no qual a natureza pode desenvolver plenamente, na humanidade, todas as suas disposições (IaG, AA VIII:27 — grifo nosso).

Caberá investigar o que é essa natureza que se fala noutro ponto desta mesma investigação: a questão sobre a natureza que trata da filosofia política e a filosofia da história será tratada no segundo capítulo sob o ponto de vista de "garantia" da história à paz perpétua, noção introduzida no opúsculo d'À paz perpétua.

\footnotetext{
${ }^{77}$ Nesse contexto, pode-se falar da diferenciação entre o direito racional (Naturrecht: a ideia de direito que serve de fundamento ao direito positivo, portanto acessível a todos os seres racionais porque se pauta exclusivamente na razão) e o direito positivo (aquele que necessita ser promulgado, cf. MS, AA VI:311). Do ponto de vista político, o direito racional está ligado a uma vontade presumível (abstrata, racional); o direito positivo é a vontade expressa.

${ }^{78}$ A ideia de progresso tem uma tensão interpretativa essencial: o que progride? De um lado, acredita-se que o progresso esteja limitado ao progresso jurídico e político, isto é, que o progresso seja institucional — é o caso de Otfried Höffe (Immanuel Kant. São Paulo: Martins Fontes, 2005, p. 270) e de Yarmiyahhu Yovel (Kant et la philosophie de l'histoire. Paris: Meridièns Klincksieck, 1989, p. 116-117/127, passim), que tece os seguintes comentários: "O objetivo global da História compreende, para Kant, um sistema bipartite. Ele possui um aspecto interno (moral) e um outro externo (legal). (...) Acrescenta que o progresso político e aquele da civilização são uma condição prévia ao desabrochar e à expansão da comunidade ética". Ou seja, que progresso institucional atue facilitando o esclarecimento e a moralidade. Pauline Kleingeld ("Kant, história e a ideia de desenvolvimento moral". In: Cadernos de Filosofia Alemã, vol. XVIII, jul-dez/2011, p. 109) acredita que é lícito falar em desenvolvimento moral.

${ }^{79}$ Segundo Allison, Kant se ocupava da Fundamentação da Metafísica dos Costumes pouco tempo antes da confecção da Ideia universal de um ponto de vista cosmopolita. Ele acredita que o excurso teleológico (GMS, AA IV:395) fosse um reflexo da preocupação, que já vinha tomando corpo no pensamento kantiano, referente à questão sobre a espécie e que seria expressa nas segunda e terceira proposições da Ideia universal de um ponto de vista cosmopolita. A argumentação dos dois trechos guarda bastantes semelhanças entre si, acercando-se da noção que a natureza deu um claro indício do uso da razão ao dotar o homem com a capacidade racional: em vez de tê-lo deixado somente com o instinto (como todos os outros animais a fim de que buscasse sua felicidade somente por ele e assim assegurasse o êxito da empreitada), a natureza dotou o homem de razão e quis que ele buscasse subsistir por meio dela. Como a razão não é instintiva, o homem necessita de tentativas e erros para desenvolver-se; dado seu curto período de vida, esse é um esforço cujos ganhos acumulam-se de geração a geração, aportando benefícios à espécie.
} 


\section{II - O PERCURSO PELA POLÍTICA}

O princípio de autonomia da vontade é a capacidade ou qualidade própria da vontade de ser lei para si mesma ${ }^{80}$. Abordamos anteriormente como se constrói esse vínculo: a vontade deve se considerar como legislando universalmente através de suas máximas, de maneira que seja ao mesmo tempo autora e súdita da sua lei.

Kant afirma, tanto n'À paz perpétua quanto na Metafísica dos Costumes (na parte sobre o direito político), que toda ideia estatal implica a relação entre quem tem o poder de mandar e quem tem a obrigação de obedecer — descreve assim a relação entre o legislador e o povo ${ }^{81}$. Como já foi mostrado noutra parte desta investigação:

Aquele que comanda (imperans) através de uma lei é o legislador (legislator). Ele é o autor da obrigatoriedade conforme a lei, mas nem sempre o autor da lei. No último caso, a lei seria positiva (contingente) e arbitrária (MS, AA VI:227).

O direito positivo é contingente e arbitrário em sua raiz: então em que termos se pode explicar a autonomia jurídica? A autonomia em sua expressão jurídica se dá na medida que o sujeito se reconhece mediatamente como autor da lei na medida que está representado no ato de legislar a lei jurídica nos termos do contrato social que estabeleceu a constituição. É, portanto, a representação que estabelece o vínculo que faltava. Daí a forma constitucional perfeita ser a república: é quando a representação se apresenta de fato e imediatamente, não virtual e mediada pela "pedra de toque de todo o direito público". Na república, a pedra de toque do direito público se apresenta para o legislador como uma obrigação direta; em um despotismo, a atenção a esse postulado é quase virtuosa (pois nada senão a consciência ou a benevolência obrigaria aquele que detém a força a comedir seu poder em favor de ideias da teoria).

O postulado do direito público dá indícios de como se pode começar uma justificação da autonomia jurídica:

Do direito privado no estado de natureza surge então o postulado do direito público: “em uma relação de inevitável coexistência com todos os outros, você deve passar daquele estado a um estado jurídico, ou seja, a um estado de justiça distributiva” (MS, AA VI:307)

Se é inevitável que todos estejam juntos em um estado civil e se o tamanho dos Estados modernos torna inviável a participação direta, deve ser igualmente possível a solução para o problema da harmonização do direito em uma forma representativa de Estado com o princípio de autonomia: a solução só pode ser considerar a si mesmo como se fosse o autor direto da lei

\footnotetext{
${ }^{80}$ Cf. GMS, AA IV:440.

${ }^{81}$ Cf. ZeF, AA VIII:354.
} 
justamente por haver aceitado se fazer representar e tomar os atos do representante como se fossem seus.

\subsection{Ideias políticas}

A presente seção é um estudo das principais ideias políticas extraídas d'À paz perpétua e confrontadas com outros escritos sobre política - especialmente a parte do direito político da Metafísica dos Costumes e da segunda seção do Sobre a expressão corrente: isso pode ser correto na teoria, mas nada vale na prática.

\subsubsection{Da passagem do estado de natureza ao estado civil-jurídico}

O pensamento político kantiano estrutura-se em torno de alguns eixos fundamentais: um deles é a relação de guerra e paz. Seja na relação entre homens, seja mesmo na relação entre Estados, é forte a noção que a situação de ausência de legislação comum gera conflitos e que a resolução desse problema deve ser o fim da política ${ }^{82}$ : por meio da instituição de uma legislação comum alcançar a paz ${ }^{83}$.

N’À paz perpétua, a questão do estado de natureza e do estado civil aparece na introdução anterior aos três capita dos artigos definitivos: totaliza algumas poucas linhas e uma longa nota de rodapé. O estado de natureza é definido primeiramente de maneira negativa:

O estado de paz entre os homens que vivem juntos não é um estado de natureza (status naturalis) (ZeF, AA VIII:349).

A partir de um esforço em levantar as diversas descrições que aparecem esparsas nas obras políticas, o estado de natureza pode ser descrito como um estado de alerta constante, de ameaça que nunca cessa, que obriga a uma desconfiança e vigilância contínuas. Percebe-se a aceitação parcial da tese hobbesiana: o estado de natureza é um "estado de guerra" ainda que não haja sempre uma explosão de hostilidades - é inseguro justamente pela ausência de uma legislação comum. Tome-se o caso dos Estados como exemplo: na relação entre Estados pode-se definir o "estado de ameaça constante ainda que sem a explosão de hostilidades" como a um armistício, nos termos dos artigos preliminares: Kant esforça-se, no primeiro artigo preliminar d'À paz perpétua, em mostrar o quanto é nefasto um mero armistício entre as nações porque não passa de um adiamento de hostilidades, não a paz de fato porque se sabe, ainda que de maneira não declarada e transparente (reservatio mentalis), que a outra parte espera matreiramente por um momento propício para

\footnotetext{
${ }^{82}$ Ou "fim político supremo", cf. MS, AA VI: 354-355.

${ }^{83}$ Cf. NOUR, 2004, p. 37.
} 
retomar a guerra com quem o armistício foi celebrado. Isso gera insegurança e corrói a confiança. O mesmo ocorre na relação entre os homens.

A lógica perversa que permeia as relações no estado de natureza consiste em não ser preciso o fato consumado ("feito" 84 ) para se tomar o outro como inimigo: desencadeia-se, assim, a cultura de tratar sistemática e preventivamente o outro sempre como ameaça. É somente em um estado jurídico instituído, isto é, em um estado civil-legal, que o único a lesar é aquele que, de fato, executa uma ação que causa dano. O ponto de interesse aqui diz respeito à temporalidade: em um estado de ausência do direito público, todos são de antemão considerados inimigos, têm a tendência e a maior probabilidade de causarem mal a outrem; já em um estado jurídico, só é inimigo aquele que transgride uma ordem prévia e claramente estabelecida.

O postulado que deve estar sempre por trás de toda a exposição política kantiana é este:

Todos os homens que entre si podem exercer influências recíprocas devem pertencer a qualquer constituição civil (ZeF, AA VIII:349) ${ }^{85}$.

Portanto, o estado de paz deve ser fundado e a paz tem um caráter iminentemente jurídico, ligado a instituições públicas que garantam o estado de paz. Por que é necessário destacar o caráter jurídico que decorre da entrada no estado civil como tão importante para garantir a paz? O próprio Kant chama a atenção para o mero fato de que a cessação das hostilidades não configura a paz:

a cessação de hostilidades ainda não é a garantia da paz [...] a menos que ela seja obtida de um vizinho a outro (o que, porém, pode ocorrer somente em um estado legal) (ZeF, AA VIII:349, passim).

O fato de agora não haver hostilidades não garante que no futuro não haverá guerra: a instituição de um estado jurídico no qual o direito é público é a única possibilidade que oferece uma garantia tangível de paz.

A ideia mesma de paz sendo mediada pelo direito deve pressupor a totalidade em sua instituição ${ }^{86}$, caso contrário restará sempre o sentimento de ameaça: o peso civilizatório do direito perde força se a presunção de coerção não for aplicada a todos. O estado de paz é, portanto, o

\footnotetext{
${ }^{84}$ Feito é "uma ação que esteja submetida às leis da obrigação e na qual, portanto, o sujeito seja considerado segundo a liberdade de seu arbítrio. Por meio de tal ato, o agente é considerado autor do efeito, e este, juntamente com a ação mesma, podem ser a ele imputados se se conhece de antemão a lei em virtude da qual pesa sobre ele uma obrigação" (MS, VI:223).

${ }^{85} \mathrm{O}$ mesmo postulado pode ser encontrado também no $\$ 41$ da Doutrina do Direito expresso noutros termos, mas garantido o sentido original: "Pois no estado de natureza também pode haver sociedades legítimas (por exemplo, a conjugal, a familiar, a doméstica em geral e quantas mais se quiser) para as quais não vale a priori nenhuma lei dizendo 'você deve ingressar nesse estado', como se poderia dizer do estado jurídico que todos os homens que podem manter relações jurídicas entre si (mesmo que involuntariamente) devem ingressar nesse estado" (Ak. 306 - grifos do autor).

${ }^{86} \mathrm{O}$ direito positivo (tal como o contrato social que, pela união das vontades particulares, institui o Estado) deve ser pressuposto como aceito por todos: seria ilógico a permissão de deixar de reconhecer a autoridade do direito algum indivíduo que vivesse no interior de um Estado e se relacionasse com indivíduos que houvessem concordado com a autoridade do Estado para dirimir os conflitos e salvaguardá-los. Para Kant, "a totalidade não é outra coisa senão a pluralidade considerada como unidade" (KrV, B 111).
} 
momento civil: quando os homens decidem por se unir, formando-se povo (populus), estabelecendo então uma ordem civil ao abrir mão de sua potência natural de agir em favor de instituições públicas: o estado civil é, por excelência, um estado jurídico posto que os homens trocam sua liberdade natural por uma liberdade civil ${ }^{87}$ cerceada juridicamente de tal modo que o arbítrio de todos possa coexistir segundo uma lei universal.

Abordamos até então de maneira geral a divisão estado de natureza e estado civil. É digno de nota mencionar uma "mudança" na teoria kantiana desde o texto da Teoria e Prática até a Metafísica dos Costumes: a concepção do estado de natureza parece ser modificada quanto à sua exposição ou, ao menos, definida de maneira mais acurada no último trabalho. No Teoria e Prática (TP, AA VIII:301) pode-se ler sobre o estado de natureza que é "o estado de uma plena ausência de leis (status naturalis), onde todo o direito cessa ou, pelo menos, deixa de ter efeito" e n'À paz perpétua encontra-se a definição indireta do estado de natureza como ausência de leis (statu iuniusto $^{88}$ : estado de injustiça. Na Metafísica dos Costumes, há um refinamento ao se falar em estado de natureza e estado civil, pois o ponto central em torno do qual se articula a argumentação é o direito público enquanto princípio racional a priori (enquanto direito racional). Kant considera haver um direito privado e um direito público ${ }^{89}$ cuja diferença primordial reside que no primeiro não há instituições públicas mediando e garantindo a aplicação da lei em uma possível sociedade de homens, mas na ordem civil pública há instituições externas. Daí decorre o nome desse tipo de direito como "público", "aberto" (öffentiche Recht). O estado de natureza não pode ser um estado injusto, mas um estado de ausência de justiça ${ }^{90}$. Em Teoria e Prática há uma definição clara do conceito de direito público. É esta:

Visto que todo o direito consiste na limitação da liberdade de outrem com a condição de que ela possa coexistir com a minha segundo uma lei universal, e uma vez que o direito público (numa comunidade) é simplesmente o estado de uma legislação efectiva, conforme a este princípio e apoiada pela força, em virtude da qual todos os que, como súditos, fazem parte de um povo se encontram num estado jurídico (status juridicus) em geral, a saber, num estado de igualdade de acção e reacção de um arbítrio reciprocamente

\footnotetext{
${ }^{87} \mathrm{O}$ tema da liberdade será retomado futuramente quando da discussão entre republicanismo e liberalismo e sua relação com o pensamento político kantiano. Cabe adiantar, por ora, que a tradição de comentadores adere a uma divisão dupla entre liberdade entendida em seu caráter forte e liberdade em seu caráter fraco (aquilo que denomino liberdade em sentido fraco é a liberdade definida pelo negativo, isto é, que se exerce pela ausência de freios externos; a liberdade que me refiro em sentido forte é aquela advinda da ordem civil-legal). A liberdade aqui exposta é aquela de poder agir sem empecilhos segundo o próprio arbítrio, portanto em seu caráter fraco.

${ }^{88} \mathrm{ZeF}, \mathrm{AA}$ VIII:349 - nota de rodapé.

${ }^{89}$ Para manter a precisão textual sem que me ocupe do tema agora, visto que não é este o foco desta seção, há que se reconhecer três tipos de direito em Kant que causam confusão por sua proximidade nas traduções: o Direito Natural (Naturrecht), o direito privado (natürliche Recht) e o direito público (öffentliche Recht). Cf. TERRA, 1995, pp. 9396). Vale também consultar os comentários de Soraya Nour (2004, pp. 3-7) sobre os erros de tradução e malentendidos na interpretação kantiana.

${ }^{90}$ Cf. "Certamente o seu estado de natureza não deveria ser, por isso, um estado de injustiça (iniustus) [...] mas era na verdade um estado desprovido de direito (status iustitia vacuus), no qual, quando o direito era controverso (ius controversum), não se encontrava um juiz competente para emitir uma sentença com força de lei” (MS, AA VI:312 - grifos do autor).
} 
limitador, em conformidade com a lei universal de liberdade (chama-se a isso o estado civil) $^{91}$.

O estado de natureza é o estado de total ausência de direito (onde "direito" é sinônimo de "direito público" ou "relações jurídicas", pois ainda que haja acordos sociais, a ausência da estrutura do direito público impossibilita falar em "direito" exigível a algo). Para compreender melhor este ponto, é bom recurso lançar mão da Metafísica dos Costumes no trecho quanto ao postulado do direito público: "em uma relação de inevitável coexistência com todos os outros, você deve passar daquele estado a um estado jurídico, ou seja, $a$ um estado de justiça distributiva" (MS, AA VI: 307). Direito público é ligado à justiça distributiva, isto é, a instituições públicas que garantem a aplicação da justiça - por "instituições públicas" deve-se ler "corte de justiça"92. De uma corte de justiça se pode exigir a exequibilidade de um direito de fato, posto que tem o poder garantido de arbitrar as relações entre os homens segundo uma lei lastreada na vontade geral, fruto da união civil.

O estado de natureza é um ideal: é um recurso meramente hipotético, pois não há como se assumir que algum dia haja de fato ocorrido tal pacto. Contudo, enquanto recurso que estabelece um ponto inicial que justifique a instituição do contrato que guia à sociedade e ao Estado, merece passar por um crivo crítico: é razoável pressupor que homens em seu estado natural possam se unir e constituir uma sociedade civilmente organizada? Noutros termos, é possível no horizonte da filosofia kantiana que homens em estado de natureza desenvolvam uma noção de reciprocidade a tal ponto de abrir mão racionalmente da sua irrestrita liberdade de agir segundo seu arbítrio em função de uma cooperação protegida orientada por uma coerção comum? De acordo com a filosofia hobbesiana, como em todo o debate político da modernidade, os sujeitos poderiam passar racionalmente do estado de conflito para o estado civil (com um grau maior ou menor de aceitabilidade dessa transição) se todos renunciassem à sua liberdade selvagem. Habermas lista duas exigências para que isso fosse factível ${ }^{93}$ : em primeiro lugar, que os homens em seu estado natural teriam de ter plena consciência do significado de uma relação social cujo ponto de apoio fosse o princípio da reciprocidade; em segundo lugar, deveriam assumir de pronto uma perspectiva social, isto é, assumir inteiramente o discurso do "nós" e distanciar-se da liberdade natural pautada no "eu" — antes mesmo da instituição do contrato a fim de viabilizá-lo. O problema que se afigura é que há uma petição de princípio nesse movimento: não parece razoável que o homem egoísta em seu estado natural tenha suficientemente domínio da noção de reciprocidade e mesmo de estado jurídico a fim de instituir por vontade própria e junto com os demais o estado civil. Essa é a visão

\footnotetext{
${ }^{91}$ TP, AA VIII:292-293.

${ }^{92}$ Cf. MS, AA VI:306 (“donde podermos também denominar a esta corte de justiça mesma a justiça de um país”).

${ }^{93}$ HABERMAS, 1997, pp. 122-128.
} 
de quem, a partir do estado civil, espera justificar a ordem vigente. O homem natural de Hobbes encontraria dificuldades em transpor-se do seu estado bruto para a organização estatal: seria necessário um "autointeresse esclarecido" de todos, o que contradiria a configuração do homem original descrito por Hobbes. A questão é se a mesma crítica se aplicaria ao homem em seu estado natural kantiano: Hobbes aproxima seus homens naturais de uma racionalidade instrumental ocasional, isto é, a um cálculo de ganhos e perdas que determina o agir ou não-agir em vistas a uma situação específica ${ }^{94}$ - a partir daí, da concorrência de interesses egoístas, fundamenta o direito. Em Kant, por outra via, há dois movimentos: um "técnico" e um "teórico", por assim dizer. Primeiramente, parte da sua solução consiste em reconhecer a existência de relações jurídicas antes mesmo da instituição do contrato (o direito privado em estado de natureza «natürliches Rechts») porque "se antes mesmo do ingresso no estado civil não se quisesse reconhecer nenhuma aquisição como jurídica, nem sequer provisoriamente, então aquele estado mesmo seria impossível” (MS, AA VI:312); assim se resolve a questão "técnica" da petição de princípio. Em segundo lugar, vincula o direito a uma teoria moral mais ampla: do postulado jurídico da razão prática de um meu e um seu possíveis, isto é, o ponto de início das relações jurídicas é a propriedade — recordemonos: não faz sentido a res nullius se algo é passível de propriedade. A petição de princípio que Habermas imputa a Hobbes só é possível porque, em Hobbes, o ponto de princípio do direito são a guerra e a paz (o direito político) e não a propriedade (o direito privado): em Kant, as relações entre os homens já se dão mesmo antes do estado jurídico porque a propriedade é uma exigência da racionalidade. O que ocorre é passar de uma posse frágil (a aquisição originária é uma consequência unilateral do arbítrio e em razão disso chamada de ocupação $o^{95}$ porque exige uma posse física presente) para uma posse peremptória (uma posse garantida pela vontade geral, isto é, pelas instituições públicas e que permite a posse inteligível ou jurídica ${ }^{96}$ — a posse por reconhecimento de um título público, em que se pode dispor da propriedade sem que se esteja fisicamente ligado a ela). A fim de ordenar a posse, os indivíduos decidem-se por instituir uma ordem civil-jurídica por um pacto de todos para com todos e esse é o nascimento das pessoas do Estado (o soberano, o governo e os cidadãos).

\footnotetext{
${ }^{94}$ Habermas se refere a isso como "modo empirista" de explicação de um sistema de direitos, uma vez que se recorre a uma possível situação empírica como ponto de partida para pensar a teoria.

${ }^{95}$ Cf. MS, AA VI:259.

${ }^{96}$ Cf. MS, AA VI:249.
} 


\subsubsection{O contrato social}

Adentrar o campo do contrato social nos guia forçosamente a uma tensão, explorada por vários comentadores ${ }^{97}$, no interior da filosofia política kantiana: a miscigenação de elementos liberais e elementos republicanos no desenvolvimento do pensamento kantiano. O contrato social é o ponto que melhor exemplifica essa tensão: a ideia do contrato social é bem aceita por liberais de maneira geral, desconhecida por republicanos antigos e habilitada nos republicanos modernos ${ }^{98}$ — essa tensão é externa e anacrônica ao texto kantiano: o contrato social é ponto de fundamentação inclusive para o direito.

O primeiro artigo definitivo d'À paz perpétua traz que a constituição civil em cada estado deve ser republicana e lista, em seguida, os fundamentos dessa constituição originada segundo a ideia de um contrato social. Segue a definição mais precisa do contrato originário:

Entre todos os contratos pelos quais uma multidão de homens se religa numa sociedade (pactum sociale), o contrato que entre eles estabelece uma constituição civil (pactum unionis civilis) é de uma espécie tão peculiar que, embora tenha muito em comum, quanto à execução, com todos os outros (que visam à obtenção em comum de qualquer outro fim) se distingue, no entanto, essencialmente de todos os outros no princípio de sua instituição (constituitionis civilis) ${ }^{99}$.

Os contratos, em geral, são firmados entre vontades com vistas a uma determinada finalidade e buscam harmonizar os interesses de todas as partes contratantes: acredito ser essa a forma do contrato social apresentado por Hobbes, de indivíduos racionais que se unem com vistas a alcançar um fim que interesse a todos (o estado de paz). A novidade do contrato kantiano está em ser contrato social um dever incondicionado e primordial $^{100}$ - o homem é moralmente obrigado a abandonar o estado de guerra e perseguir o estado de paz. O contrato kantiano é pensado como um fim em si mesmo.

Ao tratar do assunto, Bobbio aponta para o fato de que o cerne das preocupações dos contratualistas clássicos era duplo: não somente a justificação do poder de maneira geral, mas uma

\footnotetext{
${ }^{97}$ Cf. SANTOS, "Kant: da reinvenção do Republicanismo à ideia de uma 'República Mundial'" In: Cadernos de Filosofia Alemã , $\mathrm{n}^{\circ}$ XVI, jul-dez/2010; BERTEN, A. "A compatibilidade do republicanismo kantiano com o modelo do contrato social". In: SANTOS, L. R.; ANDRÉ, J. G. (orgs.) Filosofia kantiana do direito e da política: seminário internacional. Lisboa: Universidade de Lisboa, 2007. Outro texto interessante, apesar de não tratar especificamente da filosofia política kantiana, para aclarar os termos da questão é HABERMAS, J. "Três modelos normativos de democracia" In: Lua Nova, $n^{\text {o } 36,95, ~ p p . ~ 39-53 . ~}$

${ }^{98}$ Haakonsseen nota que essa falsa oposição se deve aos debates políticos contemporâneos do séc. XX (notadamente aqueles de origem anglófona) que agremiaram, em polos opostos, liberais e republicanos; não há documentos que comprovem a incompatibilidade ou qualquer luta ideológica entre as duas teorias na época moderna - pelo contrário, o que se vê é uma recorrente apropriação dos filósofos políticos modernos de elementos de uma e de outra teoria (cf. HAAKONSSEN, K. "Republicanism" In: GOODIN, R.; PETTIT, P.; POGGE, T. (eds.) A companion to contemporary political philosophy. $2^{a}$ ed. Oxford: Blackwell, 2012, pp. 729-736). Esse problema (a cisão entre liberais e republicanos), vale relembrar a diferenciação feita por Benjamin Constant entre a liberdade dos antigos e a liberdade dos modernos, não seria intrínseco à modernidade mesma?

99 TP, AA VIII:289.

100 TP, AA VIII:289.
} 
reflexão sobre um tipo específico de poder que não encontra limites em parte alguma - o poder soberano. Ele é enfático:

com respeito a esse poder de vida e de morte, fundado em última instância sobre o uso exclusivo da força, a pergunta principal que os filósofos políticos sempre se puseram foi a de saber qual é a justificação deste poder. O contratualismo nada mais é que uma das possíveis respostas a esta pergunta: o problema que ele se pôs é o problema da legitimidade do poder, não o da justiça ${ }^{101}$.

Acredito não ser descabido reconhecer em Kant que, para além da finalidade do contrato ser a justificação do poder, seu papel relativamente à justiça já era posto em questão ao resguardar a igualdade dos cidadãos. Essa posição interpretativa depende de outras ideias políticas que ainda não foram tratadas - especialmente a ideia do republicanismo: Leonel Ribeiro trata de uma "reinvenção da república" por Kant porque, em vez de olhar para eventos do passado para deles extrair a república ideal, funda a república na fonte pura do direito (o contrato social). Isso abre novas perspectivas: ao mesmo tempo em que o contrato social é a origem da ideia de republica, a própria ideia do contrato também recebe influências da ideia de república. A república kantiana se funda sobre os eixos de igualdade, de liberdade e da dependência de todos a uma mesma legislação $0^{102}$ - justamente a confluência desses três ideais permite que Kant proceda a uma crítica a velhos vícios históricos como a hereditariedade das honras de nobreza e uma defesa da meritocracia como forma de justiça. Ora, a crítica às injustiças está na letra do texto kantiano e a fundamentação última é a "pura fonte do direito" (a ideia do contrato social), de maneira que parece ser razoável atribuir essa peculiaridade ao contratualismo kantiano: de se preocupar com a justificação do poder e, ao mesmo tempo, antecipar a questão da preocupação com a justiça.

Um ponto de muita polêmica é a adesão de Kant à doutrina do contrato social: seria ele um teórico do contrato? O modo de sua exposição fornece inúmeros elementos que desconstroem a ideia clássica do contrato social, a tal nível que Ricardo Terra comenta que "o contrato originário não é propriamente um pacto de associação nem um pacto de sujeição" ${ }^{103}$. Não pode ser um contrato de associação porque já existia associação antes da instituição do contrato ${ }^{104}$; bem como

${ }^{101}$ Cf. BOBBIO, N. O futuro da democracia. São Paulo: Paz e Terra, 1997, p. 143.

102 Esses três elementos me parecem ser muito mais sensatos que o mote da república francesa - igualdade, liberdade e fraternidade. A fraternidade ou a solidariedade, como se preferir chamar, parece-me referir-se mais a uma disposição do sujeito (um dever ético) que propriamente uma obrigação (jurídica) que sirva para fundamentar o Estado. Não faz sentido obrigar alguém a razoavelmente ser fraternal. Contudo, do ponto de vista do direito e da fundamentação do Estado faz todo o sentido obrigar o outro a conformar suas ações externas segundo leis universais de conduta.

103 Cf. TERRA, 1995, p. 36.

104 Bobbio (2000, pp. 144-145), comentando o direito privado kantiano, afirma ser um expediente comum aos jusnaturalistas em geral a obrigação de admitir a existência de um estado jurídico no estado de natureza porque só assim se poderia justificar o contrato. É a diferença entre a justificação jusnaturalista e a justificação positivista para o Estado. Os positivistas não teriam problema em admitir que o poder do Estado se funda unicamente na força - pela força se faz o direito e a força o mantém, segundo o princípio de efetividade de Kelsen. Vê-se, pois, que os termos positivistas mais gerais não diferem daquele ponto de vista expressado por Hume - de ser incoerente pensar em um contrato social como regulando a sociedade porque, efetivamente, a origem do poder está unicamente na força. 
não pode ser um pacto de sujeição porque tal tipo de pacto traria problemas ligados à reserva de direitos para as partes, que poderiam anulá-lo a qualquer tempo em caso de quebra dos termos acordados - uma brecha para a justificação da revolução na teoria, que é fato inconcebível para Kant, visto que o poder soberano não seria de fato soberano se convivesse com o fantasma da ruptura da ordem. Em suas reflexões, fala de um contrato que não é contrato: "entre o soberano e o povo não se realiza nenhum pactum que contenha uma condição cuja não-manutenção autorize uma das partes a anulá-lo. (...) Não é portanto um contrato, mas um pactum gratuitum"105. É essa a forma do seu contrato social: um pacto gratuito onde se põe de lado os interesses egoísticos das partes, tornando o contrato não um meio de garantia de propósitos - mas um fim em si mesmo.

Muitos tomam Kant como um teórico do contrato nos mesmos termos da tradição da filosofia moderna (aproximando-o de maneira temerária a tendências político-jurídicas que interesse ao seu intérprete). Patrick Riley, por outra via, toma Kant como o mais adequado dos teóricos do contrato social ${ }^{106}$ e suas considerações merecem ser revisitadas: justamente porque na doutrina kantiana o contrato ser entendido como uma ideia (no sentido rigoroso estabelecido na Crítica da Razão Pura e, portanto, um elemento regulador da própria razão) é um contratualismo hipotético: parece claro que o povo não poderia ele mesmo consentir de fato e em ato ao contrato e a todas as leis posteriores, mas enquanto ser moral (pertencente àquela representação de seres inteligíveis a qual o homem deve se considerar ligado, isto é, como cidadão de um mundo suprassensível pelo qual participa por ser um fim em si) é necessário tomar como verdadeiro que esse consentimento tenha se havido e continue havendo a fim de aperfeiçoar as instituições reais que aí estão. O contrato social é uma justificação hipotética do ponto de vista da efetividade do direito positivo mesmo, mas necessária do ponto de vista filosófico se tivermos em vista a justiça. A relação kantiana com a tradição do contrato é paradoxal: tomar o contrato como ideia separa Kant de uma tradição que, afinal, ele está se filiando explicitamente.

Onora $\mathrm{O}^{\prime} \mathrm{Neill}^{107}$ encara a questão sob outro ponto de vista: radicaliza a especificidade do contrato como "ideia" e afirma que isso justamente desautoriza tomar Kant como um contratualista. Aponta para uma tensão ou concorrência entre o princípio universal do direito (da liberdade de cada um coexistir com a liberdade dos demais segundo uma lei universal) e o consentimento dos cidadãos ao largo das obras político-jurídicas para legitimar o poder ("instituir uma sociedade justa", em suas palavras). Afinal, pergunta-se, qual princípio tem prioridade na teoria kantiana? Há textos em que a justiça de uma sociedade aponta para o princípio do direito,

\footnotetext{
${ }^{105}$ Cf. KANT, Refl. 8049 apud TERRA, 1995, p. 36.

${ }^{106} \mathrm{Cf}$. RILEY, P. "On Kant as the most adequate of social contract theorists". In: Political Theory, vol. 1, n 4, 1973, pp. 450-471.

${ }^{107}$ Cf. O'NEILL, 2012.
} 
ao passo que noutros textos o contrato é tido como a pedra de toque da legislação pública. Sua saída é mostrar que Kant constantemente afirma o princípio universal do direito como prioritário e como condição sine qua non, ainda que relativize ao longo de seus escritos a questão do consentimento dos cidadãos: o princípio do direito tem maior relevância.

O trecho mais emblemático para afirmar as teses de Riley ou mesmo de O’Neill é:

\begin{abstract}
Este contrato (chamado contractus originarius ou pactum sociale), enquanto coligação de todas as vontades particulares e privadas num povo numa vontade geral e pública (em vista de uma legislação simplesmente jurídica), não se deve de modo algum pressupor necessariamente como um facto. [...] Mas é uma simples ideia da razão, a qual tem no entanto a sua realidade prática indubitável: a saber, obriga todo o legislador a fornecer as suas leis como se elas pudessem emanar da vontade colectiva de um povo ${ }^{108}$.
\end{abstract}

Descortina-se então o que poderíamos considerar a primeira solução para o problema da legitimidade da lei jurídica: a ideia do contrato social como "pedra de toque" para toda legislação, pois "obriga todo legislador a fornecer as suas leis como se elas pudessem emanar da vontade coletiva de um povo inteiro e a considerar todo súdito, enquanto quer ser cidadão, como se ele tivesse assentido pelo seu sufrágio a semelhante vontade" (TP, AA VIII:297). Essa solução, contudo, ainda não é definitiva porque se atenta apenas ao ponto de vista do legislador, enquanto que a doutrina kantiana é mais abrangente. O problema da tensão entre o princípio da autonomia e a lei jurídica fruto da representação republicana permanece.

Trate-se agora da constituição da vontade coletiva e pública que Kant faz referência. Para o ato de constituição, é necessário que todos participem. Aqui acredito que Kant está revisitando Rousseau:

Sem dúvida, o querer de todos os homens individuais de viver numa constituição legal segundo princípios de liberdade (a unidade distributiva da vontade de todos) não é suficiente para este fim, mas é necessário que todos juntos queiram este estado (a unidade coletiva da vontade unificada) (ZeF, VIII:371).

Kant, seguindo Rousseau, opõe-se a uma totalidade matemática, isto é, à mera soma das vontades individuais. A totalidade a que se refere deve ser uma totalidade coletiva, completamente nova - a união das vontades particulares não é numérica, mas forma uma vontade unida coletiva completamente nova; essa vontade não é empírica, mas completamente a priori.

Anteriormente foi dito que sair do estado de natureza era um dever e que o contrato social era um fim em si mesmo, o que o diferenciava de todos os outros tipos de contrato. Cabe compreender melhor essas afirmações.

A sociedade é um tipo de união que exige uma cooperação entre seus membros, isto é, no conceito de sociedade encontra-se necessariamente dois pontos: a. uma associação, voluntária e originalmente hierarquicamente rasa; b. dada a forma plana das relações entre os associados, têm

${ }^{108}$ Cf. TP, A 249-250. 
a possibilidade de coordenação mútua. Noutras palavras, uma sociedade se compõe com vistas a um propósito comum entre seus membros. O direito inato de humanidade serve como uma restrição sobre como as pessoas podem ser tratadas, mas também como é permitido que sejam tratadas pelos outros e mesmo nas instituições públicas que podem ser autorizadas pelo contrato social ${ }^{109}$.

A união civil, que forma a vontade geral unida, não pode ser uma sociedade senão o contrato social seria um contrato como outro qualquer: um acordo entre os membros guiado por um propósito externo. $\mathrm{O}$ contrato social deve ser ele mesmo um fim e para tanto a união civil também deve ser uma união muito particular:

\begin{abstract}
Mesmo a união civil (unio civilis) não pode ser denominada sociedade, pois entre o soberano (imperans) e o súdito (subditus) não há uma relação de cooperação: eles não são associados e não estão coordenados, mas sim subordinados um ao outro. Os que se coordenam entre si têm, precisamente por isso, de considerar-se uns aos outros como iguais, na medida em que se encontram submetidos a leis comuns. Aquela união, portanto, não é uma sociedade, mas antes produz uma sociedade (MS, VI:306-307).
\end{abstract}

A união civil é o ato de formação da vontade geral, que por sua vez embasa e institui o contrato original e todas as suas decorrências. A vontade geral deve ver-se como o soberano «Souverän/Oberhaupt». O soberano é senhor supremo das terras e de todos os súditos; não como propriedade sua, mas como detentor do poder de comando. Ao cabo, o soberano é também uma ideia cuja finalidade é formar a imagem jurídica da unificação de tudo e todos necessária para instituir o Estado. O soberano não conhece limites. Para defini-lo é útil invocar os estatutos jurídicos de propriedade e posse - pode-se dizer que o soberano não pode ter propriedades (visto que em um litígio contra algum súdito não haveria juiz competente e o soberano exerceria o despotismo puro de uma democracia direta), mas que possui tudo e a todos. Tem somente direitos - não faz sentido o soberano ter deveres frente aos súditos, pois seria lícito aventar uma quebra de contrato por omissão ou transgressão de uma cláusula (o poder soberano não seria soberano, mas limitado pelo contrato). Daí decorre que não é possível ser aceita nenhuma resistência do povo ou de algum súdito ao soberano.

O sujeito que constituiu a vontade geral unida deve ver-se sob dois pontos de vista: enquanto parte do soberano, considerar-se cidadão (aquele que pode votar); enquanto parte do Estado, deve considerar-se súdito, visto que o Estado se organiza juridicamente e pelo contrato originário está obrigado a ligar-se como todos os outros à lei comum.

O Estado (aqui abordado enquanto ideia) é a ligação dos homens entre si através de leis jurídicas - uma definição não distante daquela que Kant oferece na Fundamentação da Metafísica

\footnotetext{
${ }^{109}$ Cf. RIPSTEIN, Arthur. "Kant and the circunstances of Justice". In: ELLIS, E. (org.) Kant's political thought:
} interpretations and applications. University Park: Pennsylvania State University, 2012, pp. 45-48. 
dos Costumes quanto ao que entende por reino: "a ligação de seres racionais mediante leis comuns" (GMS, AA IV:433). A ideia do Estado serve de modelo à unificação de toda comunidade política, isto é, a coesão interna da ligação entre os homens se guia pela ideia do Estado. É lícito falar em "pessoas morais" no Estado - os três poderes, por exemplo. O cidadão pode ser ativo ou passivo, sendo que para ser um cidadão ativo exige-se não tomar o Estado como mera associação - o cidadão ativo toma parte na constituição das leis; é necessária uma disposição ativa, portanto.

\subsubsection{Soberania}

N’À paz perpétua (ZeF, AA VIII:351-353) se localiza um dos mais famosos trechos da teoria kantiana das formas constitucionais. Ali, o filósofo diferencia entre a forma de governo «Form der Regierung» e a forma de soberania «Form der Beherrschung»: segundo o modo como o chefe do governo exerce o poder e segundo as pessoas que detêm o poder supremo no Estado. A forma de governo e a forma de soberania se mesclam entre si. Nos termos d'À paz perpétua, as possibilidades são as seguintes: as formas de governo são ou republicana (se representativa) ou despótica (se legislador e executor são uma mesma pessoa); as formas de soberania são autocrática, aristocrática ou democrática se, respectivamente, o poder pertencer a um só, a alguns ou a todos igualmente. Assim, o gradiente político permitiria seis possibilidades constitucionais — uma monarquia constitucional ou uma monarquia absolutista; uma aristocracia constitucional ou uma oligarquia; e a democracia não constituiria, na visão kantiana, propriamente uma forma constitucional $^{110}$. A constituição democrática é necessariamente um despotismo para Kant, contudo a soberania democrática seria bem vista? Ricardo Terra (1995, p. 44) adota a posição democrática: "o contrato original e a noção de vontade geral já indicavam que o poder supremo, a soberania, só poderia estar com o povo". É essa posição que tendemos a defender porque se harmoniza melhor na teoria com a ideia do contrato social e de uma sociedade de colegisladores. Para sermos consistentes nessa interpretação, devemos considerar portanto que a mescla dessa forma de soberania às duas formas de governo resultariam em uma democracia constitucional e em uma democracia despótica ${ }^{111}$.

A questão das formas constitucionais não se esgota aí, há uma forma mais abrangente que dá conta da seguinte divisão: anarquia (lei e liberdade sem poder), despotismo (lei e poder sem liberdade), barbárie (poder sem liberdade nem lei) e república (poder com liberdade e lei) ${ }^{112}$.

\footnotetext{
${ }^{110}$ Cf. ZeF, AA VIII:352.

111 Portanto, respectivamente, algo próximo ao conceito contemporâneo a nós de Estado Democrático de Direito e uma tirania democrática.

${ }^{112}$ Cf. Anth, AA VII:330-331.
} 
Leonel Ribeiro comenta que, "na verdade, para Kant, só há duas formas de governo que merecem esse nome, embora sejam de qualidade muito diferente - o despostismo e o republicanismo pois nem anarquia nem a barbárie são realmente formas de poder, mas antes sua negação"113

Na Metafísica dos Costumes $^{114}$, Kant fala em uma vontade unida em uma tríplice pessoa - o poder soberano a cargo do legislador, o poder executivo na pessoa do governante e o poder judiciário em mãos do juiz. Aproxima-se, portanto, de posições clássicas como a de Montesquieu.

Devemos, no entanto, ressaltar que é possível e que durante muito tempo foi efetuada a leitura crítica que compreende ser a aristocracia o melhor modelo de soberania: essa leitura, que pretendemos afastar por não se harmonizar nem com a moral em seu sentido alargado nem com as demais ideias políticas, apoia-se centralmente no conceito de cidadão. Especialmente na limitação que Kant impõe à participação na esfera da cidadania. A chave de interpretação aqui reside novamente em aclarar os termos. Democracia é uma palavra carregada de significados bastante expressivos para o leitor contemporâneo, que são anacrônicos à obra kantiana e convém depurálos. O que o filósofo entende como democracia é a democracia direta dos povos da Antiguidade. A democracia tal como se usa o conceito nos séculos XX e XXI é o que se chama "Estado Democrático de Direito" - o Estado de Direito que Kant buscava, ao cabo, fundamentar e que se encontra ligado à soberania popular (que a ideia do contrato social faz pressupor) ${ }^{115}$. A esse entendimento reforçam as palavras de que o soberano universal, "considerado segundo as leis da liberdade, não pode ser nenhum outro senão o próprio povo unido” (MS, AA VI:316).

Um ponto polêmico no pensamento político kantiano diz respeito ao limite entre direito e revolução. Contra o soberano, por parte do súdito, é lícito opor queixas, mas jamais resistência ${ }^{116}$. "Frente ao súdito", diz, “ o soberano no Estado tem somente direitos e nenhum dever": o Estado jurídico só é possível mediante a total submissão à vontade universalmente legisladora do soberano. Nenhum ato de insurreição ou rebelião pode ser justificado internamente na doutrina do direito: aí se origina uma tensão no pensamento kantiano, amplamente explorada pelos comentadores $^{117}$, que se mantém como um problema de passagem da teoria à prática. Remanesce uma ambiguidade entre os escritos kantianos sobre quem é propriamente o soberano: se o próprio povo ou se o governante «Oberhaupt». Sobre esse tema, Ricardo Terra retoma três concepções de

\footnotetext{
${ }^{113}$ RIBEIRO, 2010, p. 23.

${ }^{114}$ Cf. MS, AA VI:313.

${ }^{115}$ Não há como não estabelecer um paralelo histórico neste ponto. A Prússia do rei Frederico era um Estado de Direito em meio às potências absolutistas europeias do séc. XVIII: ele introduziu diversas mudanças na sociedade prussiana e na condução do Estado; contudo, a liberdade que se gozou em seu reinado não era irrestrita ou constitucional, mas garantida por ele (também um déspota). O cerne da exposição kantiana é a resposta para a pergunta de como garantir que o Estado de Direito seja incorporado à constituição mesma do Estado, tornando-se perene (um estado de paz).

${ }^{116}$ Cf. MS, AA VI:319.

${ }^{117}$ Cf. "É possível defender a legalidade e ter entusiasmo pela revolução? Notas sobre Kant e a Revolução Francesa". In: TERRA, 2003, pp. 101-129.
} 
soberania propostas por Peter Burg: a concepção do direito natural (na qual o povo é soberano e toda a legitimidade repousa na vontade unida do povo a partir do pacto originário), a concepção absolutista esclarecida (na qual, grosso modo, se faz uma passagem entre a teoria e as formas históricas) e a concepção puramente absolutista (na qual o povo é excluído da noção de soberania e essa forma se identifica à realidade secular da Europa do séc. XVIII). Essas três concepções de soberania ilustram os polos do problema da passagem da teoria à prática: como vimos, o objeto da Doutrina do Direito é o direito ideal, isto é, o direito natural «Naturrecht»; para ele, não há que se falar em insurreição ou rebelião visto que, se a vontade do soberano é o próprio povo unido, seria um contrassenso (do ponto de vista da teoria) rebelar-se contra a lei dada por si mesmo. Aí estaria embutida a ideia de uma constituição republicana e, portanto, de um parlamento:

Em uma constituição política elaborada de tal modo que o povo possa, por meio de seus representantes (no parlamento), resistir legalmente ao poder executivo, (...) não é permitida nenhuma resistência ativa (do povo arbitrariamente unido para coagir o governo a uma certa ação), (...) mas apenas uma resistência negativa, isto é, a recusa do povo (no parlamento) que consiste em nem sempre ceder às exigências que o governo tem como necessárias para a administração do Estado (MS, AA VI: 322).

No ambiente ideal há uma separação entre as pessoas do Estado: os súditos, o legislador (identificado ao soberano na pessoa dos representantes do povo no Parlamento) e o governo (identificado nos ministros que detêm o poder executivo). Neste ponto alcançamos claramente o que é a autonomia em sua expressão jurídica: a lei jurídica que o legislador cria é expressão da autonomia do povo na medida que o legislador é o soberano, isto é, a vontade unida do povo constituída pelos representantes eleitos. $\mathrm{O}$ ato de delegar a representação torna o representado virtualmente presente no ato legislativo.

Contudo, conforme já vimos, há dois outros pontos de vista a serem considerados: o primeiro deles, o ponto de vista da prática «Praxis», estabelece a passagem entre a doutrina teórica e a realidade empírica - nossa proposta é tomar a concepção absolutista esclarecida como o ponto de vista da prática; por fim, de outro lado, o ponto de vista da realidade histórica e que se expressa na concepção puramente absolutista da soberania. O embasamento para tal leitura encontra-se nos comentários sobre o contrato originário no opúsculo d'A teoria e prática:

Este contrato (chamado contractus originarius ou pactum sociale), enquanto coligação de todas as vontades particulares e privadas num povo numa vontade geral e pública (em vista de uma legislação simplesmente jurídica), não se deve de modo algum pressupor necessariamente como um fato. (...) Mas é uma simples ideia da razão, a qual tem no entanto a sua realidade (prática) indubitável: a saber, obriga todo legislador a fornecer suas leis como se elas pudessem emanar da vontade coletiva de um povo inteiro, e a considerar todo súdito, enquanto quer ser cidadão, como se ele tivesse assentido pelo seu sufrágio a semelhante vontade. É esta, com efeito, a pedra de toque de toda a lei pública (TP, AA VIII:297, passim - grifos nossos). 
A pedra de toque de toda lei pública é, efetivamente, uma passagem da teoria à prática no sentido de reconhecer que mesmo que o poder não esteja dividido entre o legislador e o chefe de governo, ainda assim o ato legislativo deveria guiar-se pela ideia do contrato originário. Noutras palavras, ainda que a constituição não seja uma república, deve guiar-se republicanamente: é o caso do absolutismo esclarecido de Frederico, a quem o filósofo faz rasgados elogios alhures ${ }^{118}$.

O princípio da pedra de toque de toda a legislação pública pode ser enunciado assim também:

O que um povo não pode decidir a seu respeito também não o pode decidir o legislador em relação ao povo (TP, AA VIII:304).

É interessante notar a tensão sobre o qual se assenta esse princípio: serve tanto para a perfeição da teoria do direito natural presente na Metafísica dos Costumes quanto para a prática (no sentido específico de doutrina) proposta n’À paz perpétua e no Teoria e prática. O legislador, isto é, os representantes do Parlamento eleitos pelos cidadãos devem orientar-se por esse princípio tanto quanto o monarca absolutista esclarecido também.

Eis agora a tensão definitiva de nossa investigação: que resta fazer quando a realidade empírica não corresponde à teoria e nem a prática encontra boa recepção? Seria impróprio ao filósofo encarcerar-se no puro idealismo: tanto no idealismo formal quanto no idealismo ingênuo como aquele do abbé de Saint-Pierre ${ }^{119}$. Primeiramente, reconhecer que, no mais das vezes, a soberania não coincide com o povo e sim com o governante; então, a questão que urge é procurar como se pode realizar qualquer expressão política de autonomia — a resposta aponta para o

\footnotetext{
118 Referimo-nos à argumentação presente no Resposta à pergunta: que é o Esclarecimento? Kant elogia Frederico ("século de Frederico") pela conformação da Prússia a um Estado de Direito, em certa medida republicanamente orientado pela vontade de seu senhor — ao cabo, Frederico não havia mudado a constituição monárquica absolutista prussiana, mas era ele mesmo a garantia de respeito a alguns princípios políticos do Esclarecimento. Cf. WA, AA VIII:40.

${ }^{119}$ Ao abbé de Saint-Pierre cabe o título de precursor moderno de um projeto filosófico de paz perpétua: seu "Projet pour rendre la paix perpétuelle en Europe" influenciou Rousseau e, depois através deste, a Kant. Muito do que se conhece do trabalho do abade se deve aos comentários de Rousseau, cuja apreciação aponta para o caráter irrealizável da paz nos moldes propostos pelo abade porque extremamente dependente da boa vontade dos governantes em abrir mão de seu poder, contudo um tema importante de ser tratado mas que suas "curtas vistas" também não conseguiam vislumbrar solução (para usar a expressão cunhada por ele no Manuscrito de Genebra). Kant continua a tradição de pensar um projeto filosófico para a paz perpétua e nos mesmos moldes do abade: nesse sentido, a forma do opúsculo d'À paz perpétua ser a forma dos armistícios (tão comuns na política europeia moderna) tem menos a ver com uma ironia própria do filósofo e mais a ver com seu respeito ao tema do Abade: também o projeto do abade era composto da mesma maneira de um armistício. Temos de reconhecer, juntamente com Volker Gerhardt, que o opúsculo kantiano apresenta uma teoria crítica da política consistente, isto é, um exemplo de teoria política cujo fio condutor é o tema da paz, mas ainda não explorado em toda sua potencialidade (cf. GERHARDT, Volker. "Uma teoria crítica da política sobre o projeto kantiano À paz perpétua” In: ROHDEN, Valério. Kant e a instituição da paz. Porto Alegre: Editora da UFRGS, 1997, pp. 39-57). Ao mesmo tempo, temos de rechaçar os comentários de Hannah Arendt sobre o opúsculo em função de sua ironia: “o tom irônico d'À paz perpétua, de longe o mais importante [dos escritos políticos], mostra claramente que Kant mesmo não os levava tão a sério [os escritos políticos]" (cf. ARENDT, Hannah. Lectures on Kant's political philosophy. Chicago: The University of Chicago Press, 1992, pp. 7-10). O documento digitalizado do original do abbé de Saint-Pierre pode ser conferido no site http://www.calameo.com/read/0020594285a4ea192fbe7.
} 
esclarecimento público, isto é, ao uso público da razão e a aposta de um progresso gradual da cultura pela via do esclarecimento (como isso se pode efetivar é o tema do capítulo vindouro de nossa investigação).

\subsubsection{República e republicanismo}

O termo república pode ser encontrado de duas maneiras nas obras kantianas: como Republik $^{120}$ ou como gemeine Wesen ${ }^{121}$ (cuja tradução seria algo como "riqueza comum" e bastante semelhante à expressão commonwealth do inglês). Segundo Ribeiro ${ }^{122}$ e Berten ${ }^{123}$, a expressão gemeine Wesen é um termo germanizado que, à época, correspondia perfeitamente à expressão latina res publica. O interessante do uso da expressão germanizada é sua associação fácil a termos como riqueza comum, bem comum, coisa pública e comunidade. Para fins desta investigação, não diferenciamos significados entre os termos ${ }^{124}$.

O primeiro artigo definitivo d'À paz perpétua afirma que "a constituição civil de cada Estado deve ser republicana", pois é a "única que resulta da ideia do contrato originário, sobre a qual tem de estar fundada toda a legislação jurídica de um povo" (ZeF, AA VIII:349). A ideia de uma constituição republicana se sustenta sobre três princípios: a. da "liberdade «Freiheit» dos membros de uma sociedade (como homens)"; b. da "igualdade «Gleichheit» dos mesmos enquanto cidadãos «als Staatbürger»"; c. da "dependência «Abhängigkeit» de todos a uma única legislação comum (como súditos «als Untertanen»)". Esses três princípios ${ }^{125}$ apontam

\footnotetext{
${ }^{120}$ A expressão Republik só é recorrente n'À paz perpétua.

${ }^{121}$ A expressão gemeine Wesen é recorrente nos tratados da Teoria e Prática e o Ideia de uma história universal (na sétima proposição).

122 RIBEIRO, 2010, p. 15.

${ }^{123}$ BERTEN, op. cit., p. 21

${ }^{124}$ É de se notar, contudo, que em escritos como Ideia de uma história universal de um ponto de vista cosmopolita e o Teoria e prática é questionável que a tradução entre os termos seja simétrica: estaria a noção de "república" já definitivamente lapidada quando o filósofo escreveu esses textos? Parece-nos mais viável escolher a tradução de comunidade, nesses textos, para as ocorrências de gemeine Wesen. Essa minúcia de tradução, contudo, não interfere em nossa presente argumentação.

125 É interessante analisar o agente detentor de cada direito ou dever enunciado: liberdade - homem, igualdade cidadão e dependência jurídica - súdito. Livre (como enuncia a moral) é todo ser racional dotado de vontade; cidadão, todas as pessoas independentes em sua sobrevivência, isto é, não fazia parte de seu conceito de cidadão aquelas pessoas que eram dependentes de outros para sobreviver (seja financeira ou intelectualmente). Contudo, para que o direito surta efeito é necessário considerar a totalidade - ninguém pode se furtar de deveres jurídicos, abandonar o estado civil a seu bel-prazer ou quando lhe for conveniente. O conceito de cidadania é parte do problema teórico-político justamente por sua relação tão estreita com o contexto histórico de Kant - razão de não o tratarmos pormenorizadamente agora. Sobre o cidadão, segue uma pequena definição (TP, AA VIII:295 - grifos do autor): "Chama-se lei fundamental à que apenas pode provir da vontade geral (unida) do povo, ou contrato originário. Ora, quem tem direito de voto nessa legislação chama-se um cidadão [citoyen], isto é, cidadão do Estado [Staatsbürger], e não cidadão da cidade [bourgeois]. A única qualidade que para tal se exige, além da qualidade natural (não ser criança ou mulher), é ser o seu próprio senhor".
} 
necessariamente para a ideia do contrato originário que, como foi referido anteriormente, é considerado a fonte pura do direito ${ }^{126}$.

Cabe agora uma análise de tais princípios. Quanto à origem, dois princípios parecem incontroversamente ser tratados como decorrência exclusiva da vigência de um estado civil portanto efeito do contrato social (igualdade e dependência à uma legislação comum); um único deles participa tanto do momento anterior ao direito público (estado de natureza) quanto do momento estatal: a liberdade.

A liberdade é o princípio que subjaz da passagem do estado de natureza ao estado civil, mudando sua natureza, mas preservando-se no sistema - e nisso Kant parece acompanhar Rousseau na distinção entre liberdade natural e liberdade civil ${ }^{127}$. Liberdade, referindo-se à constituição republicana e ao contrato social, diz respeito aos homens como membros de uma sociedade e isso deve ser entendida como liberdade em geral - Kant não se refere aí a uma liberdade qualificada, isto é, um tipo específico de liberdade. Em nota de rodapé a esse mesmo trecho que evoca uma liberdade em geral, Kant se refere a um tipo específico de liberdade como liberdade jurídica:

Liberdade jurídica (por conseguinte exterior) não pode, como se está acostumado a fazer, ser definida pela autorização: "fazer tudo o que se quer, desde que não se cometa injustiça com ninguém" (...) Minha liberdade exterior (jurídica) deve antes ser definida assim: ela é a autorização de não obedecer a nenhuma lei exterior a não ser àquelas a que pude dar meu assentimento (ZeF, AA VIII:349-350, passim).

Aqui reside um outro ponto-chave desta dissertação: anteriormente defendemos que a liberdade kantiana deve ser compreendida como autonomia; devemos investigar agora os limites de se compreender a liberdade no campo da política (a liberdade jurídica) como autonomia. O problema central aqui é que podemos encarar a autonomia como fundamentando a liberdade jurídica, contudo o princípio de autonomia não pode determinar inteiramente a liberdade política. $\mathrm{O}$ ponto a que quero chegar é que a liberdade jurídica concerne essencialmente às ações externas que podemos tomar (o direito concerne ao arbítrio e, portanto, à esfera da liberdade externa), ao passo que a autonomia concerne às considerações internas do sujeito para agir de determinada maneira. Ao cabo, pode-se fazer o sujeito agir como se fosse autônomo (os efeitos de sua ação coadunar-se-iam com um possível reino dos fins), mas isso não significa necessariamente que o sujeito atue autonomamente: ao Estado não compete dizer o que é a felicidade aos sujeitos, mas fazer com que atuem em respeito recíproco na persecução de seus próprios fins subjetivos. É

\footnotetext{
${ }^{126}$ Cf. ZeF, AA VIII:351-352.

127 Acreditamos que não seria errôneo falar em "liberdade política" ou "liberdade civill". Contudo, o uso do termo "jurídica" soa mais afim ao texto kantiano porque no original em alemão consta "rechtliche Freiheit" para se referir à liberdade própria do direito garantido por instituições públicas do estado civil-legal: uma ligação inequívoca ao direito que preferimos não ignorar.
} 
necessário pensar a autonomia para tomar os indivíduos como fins em si mesmo e, desta maneira, pensá-los como dotados de dignidade e capazes de perseguir seus próprios fins. Contudo resta a questão que a liberdade jurídica, isto é, as ações conformes ao direito não são dependentes da autonomia plena do indivíduo: heteronomamente, pelo medo da coação, a ação deste último pode ter resultados bons e estimáveis. A autonomia tem uma relação de fundamento, mas não de imanência à natureza da liberdade jurídica.

Justamente ao fazer parte do pacto, o indivíduo abre mão incondicionalmente de sua liberdade original de agir como juiz e executor para recuperá-la de maneira nova, isto é, de maneira jurídica. A igualdade que o filósofo afirma é aquela adquirida enquanto cidadão e, portanto, decorrente da união civil: não se há que falar em direito de igualdade no estado de natureza até porque não há direito ali, não há um poder externo estabelecido a quem se possa demandar um direito - uma corte que administre a justiça distributiva. Nessa questão (da isonomia), a humanidade conheceu três formas de aplicar o conceito, que corresponderam a três momentos bastantes distintos em sua história: a primeira forma era aquela em que a lei era aplicada igualmente aos iguais de um mesmo estamento ou mesma classe, porém havia uma acentuada desigualdade entre esses estamentos ou classes - a esse momento corresponde a maior parte dos regimes políticos da Antiguidade de maneira geral e cujo ápice foi o sistema feudal; a segunda forma, a ideia de que todos deveriam ser iguais perante a lei, denotando que a lei deve ser aplicada indistintamente aos membros de uma mesma sociedade - a esse momento corresponde a Idade Moderna, a ascensão da burguesia e seu posicionamento questionador dos privilégios da nobreza; e na terceira forma, de que não só a lei deve ser aplicada respeitando-se as desigualdades dos desiguais e de forma igual aos iguais, mas que o Estado deve ativamente promover a igualdade. A igualdade kantiana se encaixa indubitavelmente na segunda forma de entendimento, sendo uma noção liberal de igualdade objetiva (sem considerar promover a igualdade material). É no sentido de reclamar uma igualdade na lei que, durante À paz perpétua, Kant faz um excurso contra os privilégios para se alçar a honras públicas ${ }^{128}$. Esta me parece ser a chave para compreender a utilidade "prática" de se considerar o contrato social como fonte do direito: a vontade geral nunca decidiria em um contrato originário que seria legítima a desigualdade de parte dos homens frente a outra parte; isso iria contra a noção mesma de reciprocidade. Kant põe a habilidade de cada sujeito como critério da honra, não a hereditariedade. Assim, não parece ser o caso de efetuar uma interpretação de defesa da atuação do Estado a fim de promover uma igualdade material:

${ }^{128}$ Cf. TP, AA VIII:292-293, onde defesa similar pode ser encontrada. 
Esta igualdade universal dos homens num Estado, como seus súditos, é totalmente compatível com a maior desigualdade na qualidade ou nos graus de sua propriedade, mas segundo o direito, [...] são porém, enquanto súditos, todos iguais (TP, AA VIII:291-292).

A dependência de todos a uma única legislação comum, Kant diz sumariamente que "não é necessária nenhuma explicação a propósito do princípio da dependência jurídica, já que este está implícito no conceito de uma constituição política" (ZeF, AA VIII:350). Ficamos às cegas. Contudo, cabe notar que Kant oscila entre os termos dependência «Abhängigkeit» n'À Paz perpétua e independência «Selbständigkeit/sibisuficientia» dos cidadãos uns aos outros no Teoria e Prática e na Metafísica dos Costumes. No Teoria e Prática (TP, AA VIII:294) pode-se ler: “A independência de um membro da república como cidadão «Bürger», isto é como co-legislador". A questão da independência remete diretamente ao conceito de cidadão, a questão da dependência de todos a uma legislação única comum mantém a questão nos limites puramente teóricos do contrato. Todos, sejam pessoas naturais ou pessoas morais (o Estado e seus representantes) são iguais no dever de cumprimento da lei - exceção feita ao soberano (que para ser soberano não pode encontrar limites em seu poder).

\subsection{A "garantia" da paz pela história}

Para seguir fiel à maneira que os tratados de guerra eram acordados entre as potências absolutistas europeias modernas, Kant também oferece uma garantia como uma das cláusulas ao seu projeto filosófico de paz. A garantia nada mais é do que

a grande artista natureza (natura daedala rerum), em cujo curso mecânico transparece visivelmente a finalidade de fazer prosperar a concórdia pela discórdia dos homens, mesmo contra a sua vontade ( $Z e F$, AA VIII:360).

Deve-se ter em mente que essa natureza não é a mesma natureza descrita na Crítica da Razão Pura, que é fenomênica, passiva, mecanicamente regida por leis naturais às quais o homem pode conhecer ao se dirigir à natureza com questões científicas: é a "natureza tomada como conjunto de objetos da experiência" ${ }^{29}$. Essa outra natureza, aquela que se fala n'À paz perpétua (natura daedala rerum) se faz muito presente nas obras de política e filosofia da história kantianas. A Ideia de uma história universal de um ponto de vista cosmopolita nos auxilia a formar o retrato dessa natureza: é ativa - uma natureza que quer, que se serve de meios e que obriga; respectivamente ao uso desses verbos que aqui elencamos, assim a descreve o terceiro, o quarto e o quinto artigos desse tratado.

${ }^{129}$ Cf. KrV, B XIX. 
Não se trata bem da questão de provar que haja de fato uma finalidade embutida na natureza, mas que a razão humana pode reconhecer essa finalidade como um dispositivo próprio para tornar inteligível fenômenos aparentemente desconexos entre si: ao homem parece haver uma finalidade embutida no curso mecânico das coisas, de maneira que as palavras "destino" ou "providência" conviriam para descrever essa natureza (desde que com a ressalva fundamental que não caberia aí qualquer interpretação de caráter místico que conferisse uma autoridade exterior tal que inviabilizasse a realização da autonomia humana no curso da história - aí sim seria um claro conflito com o pensamento kantiano). É uma natureza teleológica, pensada como uma providência e que se mantém nos limites da experiência possível, fruto da concepção humana de que um autor do mundo lhe determinou com fins - o caráter de "providência" lhe é conferido justamente a partir da sensação dessa predeterminação dessa natureza pelo homem ${ }^{130}$.

A natureza "age" através do mecanismo das disposições contrárias, que é o conflito ou embate entre aspirações opostas. O campo de conflito é tanto interno quanto externo aos homens: do ponto de vista do conflito interno, Ricardo Terra fala em um antagonismo no qual os homens são compelidos por querer se afastar o quanto mais dos outros homens para que tudo que tenham seja dirigido exclusivamente a si, mas, ao mesmo tempo, se veem inclinados à associação (tanto porque melhor se tem noção de si na interação social como também pela inclinação de fazer uso instrumental dos outros homens para a autossatisfação). A insociável sociabilidade é o meio pelo qual a natureza age com a finalidade de gerar um desenvolvimento generalizado que vai desde a ocupação de terras distantes e inóspitas do planeta até uma complexa organização jurídica capaz

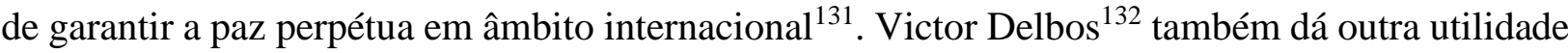
a esse mecanismo: é a via que a natureza se utiliza para manter a espécie humana em vida social, assim garantindo a cultura e o progresso da razão.

Do ponto de vista externo do conflito, é o estado de interina tensão com relação aos demais homens e que pode resultar em um embate direto. É quando cada um se sente constantemente ameaçado pelo desejo e pelo medo de ser tornado meramente um meio para a satisfação do outro. Kant também lembra que o espaço habitável do planeta é restrito e, portanto, é forçoso que os homens devam pôr-se em termos uns com os outros: a solução para o impasse é o acordo.

Pode-se considerar a história da espécie humana, em seu conjunto, como a realização de um plano oculto da natureza para estabelecer uma constituição política perfeita interiormente e, quanto a este fim, também exteriormente perfeita, como o único estado no qual a natureza pode

\footnotetext{
${ }^{130}$ Cf. ZeF, AA VIII:361-362.

${ }^{131}$ ZeF, AA VIII:363 diz que "a organização provisória da natureza consiste em que ela - 1) providenciou que os homens em todas as partes do mundo possam aí mesmo viver; 2) através da guerra, levou-os mesmo às regiões mais inóspitas, para as povoar; 3) também por meio da guerra, obrigou-os a entrar em relações mais ou menos legais".

${ }^{132}$ Cf. DELBOS, 1969, p. 224.
} 
desenvolver plenamente, na humanidade, todas as suas disposições. Avizinha-se um problema interpretativo da filosofia da história kantiana que é tangente a uma das teses que pretendemos tratar aqui: a relação entre o fim último da história (a cultura) e o fim terminal da criação (que é a paz intermediada pelo direito) — de maneira que o fim terminal só se dá a reconhecer a partir da política (como doutrina prática do direito). Não há dificuldades no salto do direito à política nesta altura de nossa argumentação. A questão aqui é saber se a constituição política perfeita é o fim último que a filosofia da história põe à espécie humana ou se é a condição facilitadora ${ }^{133}$ para um fim maior (o aperfeiçoamento moral da espécie humana).

Acreditamos que devemos tomar a constituição política perfeita como uma espécie de condição que auxilia ou cria um ambiente favorável para o desenvolvimento moral do homem e nossa argumentação é que a melhor das constituições políticas lida, no limite, unicamente com o arbítrio de seus cidadãos enquanto relativamente à liberdade externa (portanto jurídica). Tomar a constituição política perfeita como fim último da história alijaria a razão prática em sua metade, pois a liberdade externa tem a ver meramente com a legalidade das ações; a moralidade de uma ação tem a ver com o móbil que a inspira; vale relembrar, que a ação moral deve ser motivada incondicionalmente pela lei, isto é, pelo respeito ao dever — portanto segundo o imperativo ético de agir conforme ao dever por dever. Outro problema que decorre de tomar posição contrária a esta é de ir contra a letra do próprio texto kantiano na oitava proposição da Ideia universal de um ponto de vista cosmopolita:

Pode-se considerar a história da espécie humana, em seu conjunto, como a realização de um plano oculto da natureza para estabelecer uma constituição política perfeita interiormente e, quanto a este fim, também exteriormente perfeita, como o único estado no qual a natureza pode desenvolver plenamente, na humanidade, todas as suas disposições (IaG, AA VIII:27).

Encontramos uma relação desse ponto do pensamento kantiano com uma noção explicitada no texto d'À paz perpétua (publicado onze anos depois do texto sobre a filosofia da história) no qual se mantêm os mesmos fundamentos básicos quando Kant fala da garantia da paz perpétua. É o conhecido trecho kantiano sobre o povo de demônios:

O problema do estabelecimento do Estado, tão duro como isso soe, pode ser solucionado mesmo no caso de um povo de demônios (se somente eles tiverem entendimento) e exprime-se assim: 'ordenar uma multidão de seres racionais, que no todo exigem leis universais para sua conservação, das quais, porém, cada um está inclinado a eximir-se em segredo, e estabelecer sua constituição de modo que, embora tentem uns contra os outros em suas disposições privadas, as contenham uns aos outros de modo que o resultado em sua conduta pública seja justamente o mesmo como se não tivessem nenhuma das tais más disposições'. Um tal problema tem de ter solução. Pois não é o aperfeiçoamento moral dos homens, mas somente o mecanismo da natureza (ZeF, AA VIII:366)

${ }^{133}$ Cf. NADAI, 2011, p. 10. 
Depreende-se daí que mesmo a constituição política, qualquer que seja, não é dependente do aperfeiçoamento moral do homem nem é sua expressão máxima: para seres racionais imperfeitos, quaisquer que sejam, a organização estatal é necessária. A análise desse excerto centra-se invariavelmente no caráter racional até mesmo do povo de demônios, enfraquecendo as disposições contrárias que devem ser constitutivas deles mesmos - só se é demônio porque, ao cabo, tem-se a liberdade de escolher fazer aquilo que não é praticamente bom, ou seja, escolher não cumprir o mandamento da razão. Desta maneira, apesar da figura forte que o filósofo se utiliza para fazer a ilustração do problema, seus termos estão bem postos: a organização estatal ou, a dizer o mesmo, a constituição política é um mecanismo natural. A disposição moral só entra no problema quando se intenta a perseguir a constituição política perfeita, isto é, a organização estatal republicanamente orientada. Ainda assim, os termos fundamentais do problema se mantêm como estavam: a constituição política perfeita continua apenas a facilitar o desenvolvimento moral ${ }^{134}$.

O que progride é a disposição moral; não a moralidade propriamente. A civilização deve ser encarada, portanto, como um passo rumo à moralidade - mas reconhecida como um dispositivo "técnico", por assim dizer. Um trecho da Ideia universal de um ponto de vista cosmopolita corrobora nossa argumentação ao remeter à distinção entre cultivo, civilização e moralização:

Mediante a arte e a ciência, somos cultivados em alto grau. Somos civilizados até a saturação por toda espécie de boas maneiras e decoro sociais. Mas ainda falta muito para nos considerarmos moralizados. Se, com efeito, a ideia de moralidade pertence à cultura, o uso, no entanto, desta ideia, que não vai além de uma aparência de moralidade, no amor à honra e no decoro exterior, constitui apenas a civilização (IaG, AA VIII:24).

Efeito da astúcia da natureza, o progresso pelo direito é acompanhado por uma 'educação moral do povo' ${ }^{135}$. Veremos adiante o que pode ser compreendido como a autonomia em sua expressão política: o uso público da razão; a máxima tem de ser compreendida como a matéria pelo qual o uso público da razão, alcança seu mais alto grau de influência cultural e promoção da

\footnotetext{
${ }^{134}$ Há uma terceira via de caminho a se seguir, apontada tanto por Nadai (2011, pp. 13-14) quanto por Pauline Kleingeld ("Kant, história e a ideia de desenvolvimento moral" In: Cadernos de Filosofia Alemã, vol,XVIII, juldez/2011, pp. 105-132): compreender os textos políticos como não propriamente críticos e ir em direção à segunda ou terceira Críticas (esses sim textos sistemáticos). Um representante dessa terceira via, apontado tanto por Kleingeld quanto por Nadai, é Yovel, para quem a filosofia da história kantiana não lida com o progresso moral mas unicamente com o progresso político-jurídico; para se pensar o progresso moral deve-se ir às obras que tratem do sumo-bem. Höffe (2005) também é claro ao afirmar que "Kant não submeteu a experiência histórica a uma crítica sistemática, que pudesse comparar-se com a crítica da experiência natural e a experiência moral" (p. 270). Para ele, "o progresso na história não leva à consumação da moralidade, tampouco imediatamente ao desenvolvimento da arte, ciência e técnica. (...) Kant limita o progresso à justiça política, a relações jurídicas no âmbito nacional e internacional, que como relações de direito incluem a faculdade de coagir. Porque na História se trata de acontecimentos exteriores, tampouco é de modo algum possível que seu sentido último se encontre em um progresso 'interior', em um desenvolvimento da disposição moral. O progresso só pode ser esperado no âmbito exterior, na instituição de relações de direito segundo critério da razão prática pura" (pp. 274-275). A crítica que se cabe fazer a Höffe é que se utiliza de textos kantianos com escopos bastantes diversos para criar uma unidade na filosofia da história kantiana; é fato que a intenção de Kant ao escrever $O$ conflito das Faculdades (que Höffe parece tomar como texto fundamental para elaborar o conceito de história na filosofia kantiana) é bastante diferente das intenções da Ideia.
}

${ }^{135}$ RENAULT, Alain. Kant aujourd'hui. Paris: Flammarion, 1997, p.403. 
moralização do povo - é nesse sentido que se dá o progresso pelo direito vez que já estabelecidos os requisitos minimamente razoáveis para a paz duradoura, isto é, a pacificação pela via da instituição do direito público. A noção que está por trás dessa tese é que a consciência da máxima no indivíduo concorre ativamente para uma disposição de agir eticamente pela refutação de certas práticas ou afirmação, mesmo que pela inclinação, de outras práticas (a concordância com a prática no sentido doutrinal). 


\section{III - O USO PÚBLICO DA RAZÃo COMO AUTONOMIA POLÍTICA}

O que fosse a expressão política da autonomia era uma pergunta que não se podia responder nos capítulos anteriores. No primeiro capítulo desta investigação, estabelecemos o que era o princípio de autonomia da vontade e dissemos que essa autonomia podia ser entendida como autonomia ética porque o direito somente dá leis às ações e a ética dá lei às máximas das ações o princípio da autonomia da vontade está inseparavelmente ligado às máximas que a vontade faz de leis para si. Um complicador surge no horizonte do direito: o legislador (que tem o poder de comandar ao legislar) nem sempre é o autor da lei - é o caso do direito positivo, que é contingente e arbitrário; como encontrar autonomia em seguir as leis do direito positivo? O caso é que aqui parece ser oposto: seguir as leis do direito positivo faz parecer uma submissão heterônoma completa por parte do sujeito. O direito político, contudo, solve o problema da questão: ao consentir ser representado, o sujeito deve tomar as ações do representante como se fossem as suas e, desta maneira, o sujeito (agora cidadão) se vê como autor e legislador do direito positivado. $\mathrm{O}$ ganho de conhecimento sobre a autonomia jurídica ainda não possibilitava explicitar o que se pode compreender por autonomia em sua expressão política: necessitava-se explorar o direito político para conhecer a articulação das ideias políticas que permeiam a constituição do Estado; isso é o que se fez no segundo capítulo desta investigação.

Agora podemos postular liminarmente o que seja autonomia política: o uso público da razão é a expressão da autonomia na política. Cabe, no presente capítulo, investigarmos em que sentido e como se pode compreender uso público da razão como autonomia política: advogamos que o uso público da razão tem uma materialidade própria (as máximas que expressam a pretensão do sujeito agente) e tem uma forma definida (a publicidade conforme a fórmula transcendental do direito público). Investigaremos também quais os elementos constitutivos dessa doutrina: um público a priori ${ }^{136}$ e um espaço público de debates no qual os cidadãos podem se mobilizar seja uma mobilização propositiva ou reativa anterior à positivação da lei ou uma mobilização $a$ posteriori que, neste caso, tem a ver com o progresso da sociedade ao criticar e levar a cabo o processo de esclarecimento público.

\footnotetext{
${ }^{136}$ A expressão "público a priori" tem um uso estrito aqui. O público é um elemento universal e atemporal constitutivo da fórmula transcendental do direito público - se à máxima jurídico-política resta a forma da publicidade quando abstraída de toda a materialidade, é sine qua non pensar em um público a que ela se refere independentemente de como esse público se dá historicamente. Como uma prática, é certo que a universalidade dos princípios morais que balizam a política se ligam à contingencialidade histórico-material: nesse sentido, oferecemos aqui uma análise do público a que Kant se referia em seus textos políticos e o público abstraído da contingencialidade histórica que é parte filosófica constituinte de sua doutrina teórica.
} 
O método de abordagem desta seção continuará sendo aquele seguido no decorrer da investigação: primariamente, a partir d’À paz perpétua; como característica muito própria deste bloco de investigação, será necessário seguir rumo a outros textos que já vinham sendo trabalhados — notadamente o Resposta à pergunta: que é Esclarecimento? (no qual interessa sobremaneira a distinção entre uso privado e uso público da razão) e a Fundamentação da Metafísica dos Costumes (na qual interessam as noções de máxima, imperativo categórico e reino dos fins).

\subsection{Máximas}

O primeiro e mais central contato com o conceito de máxima, no escopo da filosofia kantiana, geralmente se dá por via da Fundamentação da Metafísica dos Costumes e a Crítica da Razão Prática ${ }^{137}$ em um ambiente marcadamente orientado à moral. Devido ao papel capital da máxima na formação da lei moral, a literatura de comentadores de Kant não haveria como deixar de dispensar certa atenção ao conceito; a maior parte das abordagens sobre máximas encontram, contudo, algumas limitações logo de saída: primeiramente, a delimitação clara do ponto de partida iminentemente moral ${ }^{138}$; a segunda limitação latente é que a máxima é tratada como "mais um degrau" para se alcançar a lei moral sendo que esta, ao cabo, é de fato o ponto nevrálgico da maior parte dos comentários. A análise das máximas em geral perde riqueza em detrimento de um tipo específico de máximas - a máxima moralmente boa, isto é, aquela que atende às exigências do imperativo categórico. E como terceiro fator limitante, por fim, nota-se que alguns comentários explicativos pouco acrescentam à discussão por se aterem demasiadamente às noções de "princípio" ou de "lei moral"139. É sabido que o uso da palavra máxima «Maxime» aparece noutras obras sem que a tradição de comentadores tenha tomado essas ocorrências como tão profícuas de análise quanto as ocorrências relativas à formação da lei moral ${ }^{140}$. Nesse sentido, como veremos

137 É o caso dos comentários de Allison (1990, pp. 85-106), Beck (1960, pp. 116-125), Bittner (2004, pp. 07-25), Höffe (2005, pp. 203-206; 2009, pp. 159-178), Longuenesse (2005, pp. 236-264), Korsgaard (1996, pp. 43-76) e Webb (1926, pp. 94-95). Há também trabalhos que dão um tratamento mais alargado ao tema: Albrecht (2009, pp. 134-155), Bubner (2000, pp. 245-258), Habermas (2011, pp. 264-287) e O’Neill (1989, pp.81-104).

${ }^{138}$ Nesse sentido, como nota Klemme, ofusca-se a questão do mal. Kant iguala liberdade, lei moral e autonomia na Fundamentação da Metafísica dos Costumes: a escolha pelo mal pode explicar-se como falta de esclarecimento ou, noutras palavras, falta de razões conscientes que motivem o agir à luz do trabalho da vontade — pois ser livre é o mesmo que agir sob o princípio de autonomia da vontade. Noutras palavras, há algo que a aproximação iminentemente moral das máximas não lança luzes: para a lacuna entre o arbítrio e o trabalho da vontade. A máxima ("uma regra que o próprio arbítrio para si institui para o uso de sua liberdade" — RGV, AA VI:27) tem a ver primariamente com o arbítrio e, dessa perspectiva, toda máxima é inicialmente indiferente moralmente falando visto que é o imperativo categórico que serve de prova de moralização. O mal não pode ser atribuído a uma vontade má. Cf. KLEMME, Heiner. "A liberdade do arbítrio e o domínio do mal: a doutrina de Kant do mal radical entre moral, religião e direito". In: Studia Kantiana, $\mathrm{n}^{\circ}$ 15, 2013, pp. 5-37.

${ }^{139}$ É o caso dos comentários de H. G. Paton (1971, pp. 58-61).

${ }^{140}$ Para fins de concisão, tenha-se em mente apenas as obras do chamado "núcleo duro" da crítica: pode-se citar seu uso na $K r V$ e na $K U$ - nas quais encontramos referências às máximas da razão: "denomino máximas da razão os 
adiante, poucos exploraram mais detidamente o intercâmbio entre Maxime e Grundsatz (problema referente à formação da língua alemã): há mais de um sentido para "princípio" nos textos de Kant e a passagem entre esses sentidos se dá por vezes em uma mesma obra sem a devida atenção. Como há poucos escritos de comentadores que tratam do uso de máxima cujo ponto de partida e a abordagem não sejam estritamente éticos, então se legitima a desconfiança: até onde tais definições oferecidas encontram amparo quando extrapolamos o tratamento iminentemente ético/moral e adentramos por outros caminhos tal como aquele da filosofia política?

Pela expressão "encontrar amparo", referimo-nos a um problema de aproximação ao texto e que se expressa em duas tarefas muito pontuais e entrelaçadas que se põem para nós: de se conseguir formar uma noção ampla que se aproxime o quanto se puder do que o filósofo compreendia por máximas (a partir exclusivamente de seus textos); e, em segundo lugar, depurar os kantismos posteriores tendo clareza dos acertos e desvios inseridos pela tradição. É evidente que executar a primeira das duas tarefas postas já implica necessariamente em um nível de interpretação, mas que tem a possibilidade de estar em um primeiro nível de mediação: o leitor contemporâneo deve ter em mente que o termo "máxima" estava em moda na época do Esclarecimento, sendo muito corrente seu uso na moralística moderna, de maneira que o próprio filósofo usou o conceito em várias obras sem havê-lo tratado sistematicamente ${ }^{141}$. Não se pretende sugerir aqui que é o caso de um mapeamento das influências de outros pensadores em Kant, com vistas a estabelecer um "purismo doutrinário" (seria inclusive um esforço de resultados frágeis dada a dificuldade em estabelecer essas influências vez que nem o próprio filósofo se dedicou a tratar do conceito sistematicamente em alguma obra); é interessante notar, contudo, como os usos que o filósofo fazia em seus diversos textos coincidiam em larga medida com o uso geralmente aceito por outros pensadores contemporâneos a si: isso sugere que o uso pretendido fosse evidente por si mesmo - o que deixa o leitor atual em posição de desvantagem na exegese do texto. Sobre a segunda tarefa, é interessante notar que houve um renovado interesse no conceito de máxima

princípios subjetivos que são extraídos não da constituição do objeto, mas do interesse da razão em vista de uma certa perfeição possível do conhecimento desse objeto", diz Kant na $K r V$ (IV:694). Nesse mesmo sentido, podemos extrair, na $K U$ (V:249), a proposição "evitar a desnecessária multiplicação de princípios" como um exemplo de máxima da razão. Fundamentalmente a crítica que ora fazemos é das definições e aclaramentos na literatura de comentadores raramente abarcarem essas e outras ocorrências que fujam dos textos éticos.

${ }^{141}$ Bubner (2000, p. 246) defende que "máxima" era um conceito bastante recorrido no Aufklärung e nas Lumières. O uso franco do termo, sem que se houvesse uma definição precisa, faz lembrar também o conceito de Esclarecimento «Aufklärung»: até a pergunta "afinal, o que é o Esclarecimento?" ser posta publicamente e receber tentativas de aclaração, todos se utilizavam dele sem delimitação formal e publicamente aceita; o conceito de máxima não teve uma pergunta “afinal, o que são máximas?". Albrecht (2009, p. 136 e 140-141) tenta ser mais preciso: afirma que Maxime é um termo de origem é francesa e cuja a tentativa germânica de tradução seria Grundsatz ("princípio" ou "proposição fundamental"); a este respeito voltaremos a tratar mais adiante quando investigarmos se aí se esconde só um problema de tradução ou se há uma diferenciação conceitual. Um estudo contemporâneo sobre os principais moralistas que utilizavam francamente o termo "máxima" e o inscreveram definitivamente na filosofia moderna é SCHALK, F. (org.) Französische Moralisten (La Rochefoucauld, Vauvenargues, Montesquieu, Chamfort). Zurich: Diogenes, 1995. 
(especialmente no tocante ao tratamento que Kant dá) por duas razões externas à filosofia kantiana no século XX: por influências da filosofia de Wittgenstein ${ }^{142}$ e pelos comunitaristas neoaristotélicos ${ }^{143}$ (BUBNER, 2000, p. 247-252). Daí advém a importância de demarcar claramente o que está nos escritos kantianos e o que é próprio da literatura interpretativa posterior.

Há um objetivo maior ao se tratar de máximas neste capítulo: estabelecer o funcionamento mais amplo da esfera da cultura. Ao fim desta seção esperamos haver concluído que tratar de máximas está relacionado a trabalhar com os princípios que fundamentam uma dada cultura, seja em caráter individual ou em caráter coletivo. Essa tese fica mais intuitiva quando trabalhada em relação à coletividade: podemos entender autonomia como a capacidade de autodeterminação que alguns seres têm - os seres racionais em geral ${ }^{144}$ ou, assertivamente, os seres humanos. $\mathrm{O}$ movimento que fazemos aqui é que podemos ler o trecho da Fundamentação da Metafísica dos

\footnotetext{
${ }^{142}$ Em termos gerais, o problema que Wittgenstein lidava era em razão da filosofia da linguagem: para que se possa participar de uma comunidade organizada em torno da linguagem e reconhecer seus códigos, é necessário anteriormente a capacidade de reconhecer e lidar com regras para (1) aprender a linguagem mesma; (2) derivar, a partir da linguagem, comportamentos; (3) investigar como usos aparentemente não-morais tornam-se morais - como é o caso de uma promessa, isto é, como uma intenção futura se converte em obrigação.

${ }^{143}$ As críticas comunitaristas centradas fortemente contra o caráter universalista da filosofia moral kantiana. Chama a atenção a reação às críticas de excesso de formalismo e falta de uma práxis na doutrina kantiana: uma espécie de "vida boa" embutida nas máximas (nas quais se alinham os trabalhos de Rüdiger Bittner e Otfried Höffe — oportunamente tais posicionamentos serão retomados).

${ }^{144}$ Há um cuidado que se deve tomar de saída na interpretação de "seres racionais em geral": pode ser lido como estabelecendo um segmento cujo ponto limite fica aberto (todos os humanos e quaisquer outros seres que porventura tenham racionalidade ainda que desconhecida sua existência) ou no sentido pretendido na Fundamentação da Metafísica dos Costumes entendido como totalidade lógica. Estritamente, se tomarmos o uso da expressão "em geral" nesse último sentido devemos proceder à mesma diferenciação que Kant e separarmos os "seres racionais em geral" naqueles que têm uma vontade finita de um lado, de outro lado aqueles têm uma vontade infinitamente boa (vontade santa). A explicação para isso é a dúvida razoável que resta expressa nestes termos: visto que a máxima é um princípio que se relaciona sempre à subjetividade, por acaso a máxima se aplicaria também a uma vontade perfeitamente boa? A vontade perfeitamente boa, nos diz Kant (VI:414), quer sempre aquilo que a lei objetiva prescreve, portanto não faz sentido falar em dever, em qualquer tipo de necessitação: "o < verbo> dever está aqui no lugar errado, porque o querer já é si por mesmo necessariamente concordante com a lei”. Explica-se: em uma vontade finita, a máxima necessita passar pelo crivo do imperativo categórico ("aja sendo uma máxima que possa valer ao mesmo tempo como uma lei universal" segundo a definição mais abrangente da MS VIII:226) para ser reconhecida como uma lei objetiva, portanto, dotada de necessitação (um mandamento). Uma vontade perfeitamente boa pode ser tomada do ponto de vista de si mesma e, assim, sua máxima seria o próprio princípio objetivo ao mesmo tempo ou essa vontade perfeitamente boa não pode ser tomada do ponto de vista de si mesma (o que incorreria no risco de torna-la a própria racionalidade)? Paton também trata do mesmo assunto e conclui o mesmo (1971, p. 61): "Kant fala, por vezes, como se todas as máximas fossem formadas sobre inclinações e, consequentemente, como se uma vontade santa ou divina não pudesse ter máximas. Uma vontade santa ou divina teria máximas que não fossem outra coisa senão também princípios objetivos; mas dizer isso não é negar que aja de acordo com máximas, se interpretarmos 'máximas' como princípios manifestados na ação". Cabe perceber que há uma delicada diferença entre nossos objetos - levantamos a possibilidade de uma vontade perfeitamente boa compreender a si mesma também subjetivamente, Paton diz que se for possível reconhecer princípios em uma ação será possível postular a máxima que guia aquela ação. Certamente Paton está ciente e se referindo ao trecho da Crítica da Razão Prática ( $K p V$, AA V:79) no qual Kant diz que "todos os três conceitos, o de um móbil, o de um interesse e o de uma máxima, podem apenas ser aplicados a seres finitos. Pois todos eles pressupõem uma limitação da natureza de um ser [...]". Sendo rigoroso, neste momento Kant nos desautoriza a aplicar a noção de máxima tanto à vontade perfeitamente boa quanto (indiretamente) a postular uma máxima para uma ação (de uma vontade perfeitamente boa como queria Paton). Isso é problemático e, à luz da primeira seção (2.1. $A$ moralidade) do II capítulo desta dissertação, suscita ser repensado sob que ponto de vista isso deve ser considerado válido: como aplicável à moralidade em sentido alargado (considerando as liberdades interna e externa unidas) ou à ética (liberdade interna)? Essas questões serão retomadas em breve.
} 
Costumes (VI:412) que diz: "toda coisa na natureza atua segundo leis. Só um ser racional tem a faculdade de agir segundo a representação das leis, isto é, segundo princípios, ou uma vontade. Visto que se exige a razão para derivar de leis as ações, a vontade nada mais é do que razão prática" como se referindo às máximas - está embutida aí, desde já, a autodeterminação, vez que a máxima é a representação de uma lei para o próprio sujeito porque exige desempenho em sua aplicação. Se admitimos que a máxima tem mais a ver com a validade que a fundamenta (ser regra que o sujeito quis como sua) do que com o mero caráter possessório (diferenciação do meu e seu), devemos admitir que a máxima tem relação direta dos seres racionais darem fins a si mesmos — e não seria essa a definição de cultura apresentada na $M S$ (VIII:392) ${ }^{145}$ ? O uso público da razão entra em questão pelos dois princípios transcendentais trazidos no II Apêndice da ZeF (no qual se pressupõe a ideia de público e de liberdade pública anteriormente trabalhada por Kant no Resposta à pergunta) que se resumem ao que denominamos "princípio de publicidade": tornarem-se públicas todas as máximas, para que por meio de sua adesão ou rechaço se verifique sua justiça ou injustiça. Tornar públicas as máximas políticas, isto é, a representação da lei que motiva o agir de um soberano ou do governante chama a um esclarecimento público, que cresce quanto mais o público se esclarecer - é um tipo de processo educativo. Ao cabo, está aberta aí a via de uma mudança cultural sem precedentes.

Esses são os termos maiores desta seção. A fim de viabilizá-los, cabe certamente fundamentar todo o caminho e faz-se necessária a retomada da abordagem comum iminentemente ética para abrir caminho para o alargamento do conceito em seu uso político - a dúvida que motiva e subjaz a essa parte da investigação é saber se a interpretação iminentemente ética sobrevive quando deslocamos essas aclarações do campo da ética para o campo alargado da moral, tendo em vista que a política deve estar em harmonia com a moral por ser, como define Kant expressamente n’À paz perpétua, a doutrina do direito em seu caráter executivo «als ausübender Rechtslehre» (ZEF, AA VIII:370).

\subsubsection{A abordagem moral}

A aproximação usualmente feita do conceito de máximas se embasa em três definições, propostas por Kant, que seguem a estrutura "máxima é": duas notas de rodapé da Fundamentação da Metafísica dos Costumes e a definição do §1 na Analítica da Crítica da Razão Prática. A primeira definição de máxima é aquela da I Seção da Fundamentação da Metafísica dos Costumes:

\footnotetext{
${ }^{145}$ Kant se refere à "cultura em geral": a faculdade de propor-se fins é o que distingue a humanidade da animalidade, de maneira que à humanidade está ligada a vontade racional - que, segundo a definição já mencionada, é a capacidade de derivar ações da representação das leis. O ser humano deve superar as disposições rudes de sua natureza por meio da cultura em geral, elevando-se da animalidade à humanidade e se tornando digno desta.
} 
máxima é o princípio «Princip» subjetivo do querer; o princípio «Princip» objetivo (i.e. aquilo que serviria subjetivamente de princípio prático para todos os seres racionais se a razão tivesse pleno poder sobre a faculdade apetitiva) é a lei prática (GMS, AA IV:400).

A ela, segue-se esta segunda nota localizada na II Seção da mesma obra:

Máxima é o princípio «Princip» subjetivo para agir e tem de ser distinguida do princípio «Princip» objetivo, a saber, a lei prática. Aquela contém a regra prática que a razão determina em conformidade com as condições do sujeito (muitas vezes em conformidade com a ignorância ou também com as inclinações do mesmo) e é, portanto, o princípio «Grundsatz» segundo a qual o sujeito age; a lei, porém, é o princípio «Princip» objetivo, válido para todo ser racional, e o princípio «Grundsatz» segundo a qual ele deve agir, isto é, um imperativo (GMS, AA IV:420).

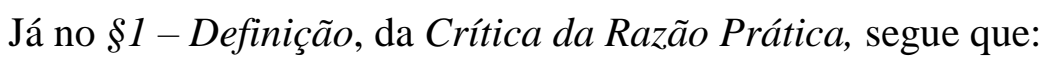

princípios «Grundsätze» práticos são proposições «Sätze» que contêm uma determinação geral «allgemein» da vontade, que compreende sob si várias regras práticas. Elas são subjetivas, ou máximas, se a condição é considerada pelo sujeito como válida apenas para a sua vontade; mas são objetivas, ou leis práticas, se a condição é reconhecida como objetiva, isto é, como válida para a vontade de todo ser racional (KpV, AA V:19).

Essas são as três definições clássicas e que conseguem adensar em si os principais temas quando se trata de máximas: que a máxima é um princípio; que esse princípio é subjetivo; que esse princípio é prático, posto que se relaciona seja ao querer, seja ao agir e inequivocamente ao trabalho da vontade; que esse princípio tem sob si diversas outras regras práticas; e, implicitamente, que máximas são princípios no sentido de serem proposições (há um esforço de formulação consciente embutido - ainda que não se aclare o suficiente se esse esforço é no sentido de reconhecer uma ação e postular seu princípio orientador ou de deliberar e dar a si mesmo o princípio de orientação antes da ação).

O que temos de imediatamente seguro é que todas as definições têm em comum igualar máximas a princípio: comecemos, portanto, por estabelecer o que seja princípio. Na literatura de comentadores, é Paton (1971, p. 59) quem centraliza sua análise de máximas à noção de princípio, portanto é a ele que se recorre primeiramente: "um princípio [é], em geral, uma proposição universal que tem sob si outras proposições das quais é o fundamento: por essa razão, é também chamado de 'proposição fundamental' (Grundsatz)". Nada foi trazido além do que o próprio texto kantiano já nos havia dado conta ${ }^{146}$, contudo a explicação de Paton estabelece inequivocamente a ligação do termo máxima com sua gênese clássica na lógica pela aclaração semântica do próprio conceito. Vários comentadores trazem referências à apropriação do termo "máxima” pela

\footnotetext{
${ }^{146}$ A retomar o que foi dito nas palavras introdutórias ao capítulo, é esse o cerne da crítica que se faz àqueles que se propõe a definir máxima a partir ou com vistas a alcançar a lei moral: não se afastar para longe dos conceitos de "princípios" e de "lei moral" pouco enriquece o debate na medida que se prende excessivamente às definições kantianas. A explicação cai invariavelmente em uma circularidade entre os três conceitos de maneira que a definição de um acaba necessariamente por pressupor a contraposição ao outro na definição.
} 
moralística ${ }^{147}$; Bittner (2004, pp. 14-15), por exemplo, traz a seguinte explicação como nota de rodapé:

com sua determinação como princípio, o conceito kantiano de máxima dá continuidade à tradição dessa palavra na filosofia antiga e escolástica. Originalmente, ela tem um sentido lógico e designa a proposição suprema, não demonstrada e aceita, de uma inferência ou de uma cadeira de inferências. Por isso, a máxima é em parte identificada com um axioma, em parte diferenciada deste apenas por sua menor certeza. Como proposição suprema, a máxima é de suma generalidade e pode ser pressuposta sem demonstração porque é aceita por todos. 'Máxima', na moralística (Moralistik), desprende-se do contexto lógico, mas mantém o mesmo sentido: uma proposição muito geral que pode prescindir de apoio argumentativo, porque é evidente a qualquer um que conheça o mundo.

Em termos gerais, em um paralelo com a forma silogística, a premissa maior seria o princípio (major propositio) e a subsunção do caso particular seria a maxima propositio (quase que literalmente traduzida para o alemão como «Grundsatz» ${ }^{148}$ ). É interessante notar que o silogismo que deriva uma determinação do querer de um princípio exige a intermediação da faculdade de julgar ${ }^{149}$, pois isso nada mais é que subsumir a um princípio maior um caso

${ }^{147}$ Moralística, para efeitos deste trabalho, são os ensaios sobre moral desprovidos de pretensão de normatividade de determinados pensadores dos séculos XVI ao XVIII — é uma palavra própria da língua alemã «Moralistik» e com amplo referenciamento bibliográfico quando no trato acadêmico de desses autores. Características em comum a esses autores são o aspecto ensaístico, aristocrático, a falta de pretensão em formar um conteúdo sistemático-normativo moral, raízes humanistas e a disposição para análise e interpretação psicologista do comportamento dos homens. Os nomes classicamente ligados à moralística nos trabalhos alemães são Montaigne, Pascal, La Rochefoucauld e Chamfort.

148 "Proposição fundamental" em português. A definição que se seguiu foi a de Webb (1926, pp. 94-95). Beck (1984, p. 81) usa o termo sententia maxima. Sobre o uso intercambiável que Kant faz entre "máxima" e "princípio" «Grundsatz», Albrecht (2009, p. 135) nota que o termo máxima foi deixado de lado por muito tempo na tradição porque desde trabalhos anteriores Kant preferiu usar a tradução «Grundsatz»; essa, aponta ele, teria sido uma das razões do conceito de máxima só ter recebido reiterada atenção da tradição com o enfoque ético - afinal, é nas obras éticas que o conceito ganha maior reconhecimento. Também é preciso cautela para ler "princípio" em Kant, pois, como Beck (1960, p. 122) alerta, Kant usa "princípio" com dois significados: ora como um produto ligado à faculdade de julgar (um "juízo básico, fundamental e sintético a priori"), ora no sentido de condição ("condição da vontade" ou "prius"). Enquanto juízo está ligado ao imperativo categórico, enquanto condição está ligado à autonomia da vontade. Eis o trecho que, ainda de acordo com Beck, demonstra a passagem entre os significados: "a autonomia da vontade é o único princípio de todas as leis morais e dos deveres conformes a essas leis: toda heteronomia do arbítrio, ao contrário, não somente não funda nenhuma obrigação, mas é além disso oposta ao princípio da obrigação e da moralidade da vontade" (KpV, V:33, §8 - Teorema). A observação de Beck encontraria respaldo (ou, ao menos, uma dúvida razoável que nos conduziria a pensar em favor de sua acuidade) quando comparada ao trecho da $\mathrm{KrV}$ (IV:356) em que Kant debate o "princípio" não ser propriamente o começo mas um conhecimento proposicional ao qual se dá status de princípio: "a expressão princípio «Princip» é ambígua e significa, vulgarmente, apenas um conhecimento, que pode ser usado como princípio, embora em si e quanto à sua origem não seja um principium. Qualquer proposição universal, mesmo extraída por experiência (indução), pode servir de premissa maior num raciocínio; mas nem por isso é um principium".

${ }^{149}$ Entendida nos termos da $K r V$ (VI:360-361):"Em todo silogismo eu penso primeiro uma regra (major) por meio do entendimento. Em segundo lugar, eu subsumo um conhecimento sob a condição de regra (minor) por meio da faculdade de julgar. Finalmente, determino o meu conhecimento através do predicado da regra (conclusio), portanto a priori, por meio da razão. Assim, a relação que representa a premissa maior como a regra entre um conhecimento e sua condição constitui os diferentes tipos de silogismo. Eles são de três tipos, portanto, assim como os juízos em geral, na medida em que se diferenciam pelo como como exprimem a relação do conhecimento no entendimento, a saber: silogismos categóricos, hipotéticos ou disjuntivos." Ou da $K p V(\mathrm{~V}: 162)$ : “a divisão da Analítica da razão prática pura terá de resultar semelhante à de um silogismo, ou seja, procedendo do universal na premissa maior (do princípio moral), mediante uma subsunção, na premissa menor, de possíveis ações (como boas ou más) sob aquela, à conclusão, 
específico: se o amor-próprio for tomado como princípio maior (major), então deve-se assumir que "mentir para evitar um mal maior para si" é uma proposição fundamental (maxima) válida derivada do princípio maior - ainda que não entremos no mérito se tal máxima é moralmente boa ou não. Dois outros autores lidam fortemente com a noção de silogismo em suas análises e extraem conclusões que merecem atenção: Beck (1984, p. 81), para quem a máxima seria a premissa maior de um silogismo; e Longuenesse (2005, p. 253-255), para quem a máxima entra diretamente na composição de um imperativo hipotético como termo consequente. Vejamos o exemplo de Beck:

$\begin{array}{ll}\text { (Máxima) } & \text { Vingar uma injustiça é sempre meu propósito. } \\ (\text { Regra }) & \text { Dizer esta mentira irá vingar uma injustiça. } \\ \text { (Decisão) } & \text { Então, proponho dizer essa mentira. }\end{array}$

O exemplo de Beck depende, primeiramente, de um esclarecimento com relação àquilo que ele compreende por "regra" (1984, p. 79-80): diagnostica que até então o uso do termo vinha sendo feito de maneira polissêmica por Kant em seus vários livros, ora se referindo a "lei", ora a “imperativo", ora a "máxima”, ora a "preceito". A partir da Crítica da Razão Prática, segundo a Definição do $\S 1$, fica estabelecido que se deve compreender regras como aquilo "concernente ao caráter empírico e contingente de agir em situações específicas, dadas as determinações gerais expressas no princípio" ${ }^{150}$. Longuenesse ${ }^{151}$ lê o mesmo trecho de maneira distinta: a partir do caput do §1, entende que regras são tanto as máximas quanto as leis. Seu argumento é complexo. Sob esse ponto de vista, a distinção entre máxima e lei não é entre "o que fazer" e "o que devemos fazer": a máxima tem um caráter obrigante também tanto quanto a lei, mas o verbo dever tem gradações - aquele implícito na máxima não é dotado de normatividade forte (no sentido de ser válido para todos), mas de uma normatividade fraca (no sentido de ser válido para o sujeito). Essa nova interpretação não transforma a máxima em imperativos hipotéticos, mas reconhece-as como o consequente desses imperativos que são do tipo preceito $^{152}$. O que é submetido ao imperativo

ou seja, à determinação subjetiva da vontade (a um interesse pelo bem praticamente possível e à máxima fundada sobre aquele)".

150 Talvez algo não tão distante daquilo defendido por Kant no Prefácio da Grund (IV:389) ao diferenciar regras de leis: "todo o mundo tem de admitir que uma lei, se ela deve valer moralmente, isto é, como razão de uma obrigação, tem de trazer consigo uma necessidade absoluta" de maneira que "todo outro preceito baseado em princípios da mera experiência e até mesmo um preceito de certo modo universal pode certamente se chamar uma regra prática, jamais, porém, uma lei prática na medida em que se apoia em razões empíricas". À luz do Prefácio da Grund, fica o raciocínio que todo produto da razão que não vale objetiva e universalmente, porque baseado em elementos empíricos, pode ser caracterizado como uma regra; Beck, contudo, tem como foco de análise a $K p V$.

${ }^{151}$ Cf. Longuenesse, 2005, pp. 252-253.

${ }^{152}$ Cf. LONGUENESSE, 2005, p. 253: “Aqui a distinção entre máxima e lei não é uma distinção entre 'o que fazemos' (máxima) e 'o que devemos fazer' (lei). É, antes, uma distinção entre uma regra que damos a nós mesmos (= o que devemos fazer) sob a condição particular de nós mesmos e uma regra que amarra a todos nós. Nos dois casos, há um 'eu devo', uma prescrição, mas uma é subjetiva (válida somente para mim) enquanto a outra é objetiva (válida para todos). Notemos, ademais, que estritamente falando as máximas parecem ser não os imperativos hipotéticos mesmos, mas o consequente desses imperativos, que amarram unicamente sob a condição dos antecedentes serem posicionados ou enunciados". 
categórico é justamente o preceito: se o preceito não puder ser universalizado, então a máxima que guiou o silogismo a emergir essa conclusão deve ser negada como moralmente boa.

O silogismo de Beck é marcado por uma sutil diferenciação com relação ao que Kant estabelece $^{153}$. Beck parte de uma máxima aplicada a um caso particular e deriva uma ação - sempre problemática na forma “se neste caso $x$, então fazer $x$ ". Não seria essa forma muito aproximada de um preceito prático? Do tipo de um conselho, pois pela falta do verbo dever explícito ainda não está contida aí a necessitação imediata de um imperativo. A forma problemática da decisão de Beck é, para Allison (1990, pp. 89-90), na verdade, a forma mesma da máxima: “à luz dessas considerações [sobre a ligação de máximas a interesses], a máxima pode ser considerada como um princípio prático ou regra de ação auto-impostos na forma: quando em situações tipo-s, realizar ações tipo- $a$ ". Há um entrave no salto entre a decisão problemática derivada no silogismo de Beck para a forma problemática da máxima de Allison: como coadunar essa forma problemática da máxima, por exemplo, à máxima de um sujeito que se decide a não tolerar impunemente nenhum insulto? Essa forma problemática remete-nos mais à postulação de uma "lei” da máxima por um observador externo do que propriamente a uma máxima que leva em conta o papel do eu. Se a máxima tiver a forma "quando $x$, então $x$ ", não a reduzimos meramente a uma função legislativa algorítmica?

Com relação à definição de regra (tal como Beck a compreende) ainda resta a dúvida dicotômica de como fica a máxima: é regra ou é lei? Pois, na medida em que especificamente a máxima moral tem a forma da lei universal e quando pelo ato da faculdade de julgar se reconhece a objetividade contida nela aplicando-a ao imperativo categórico, antes desse reconhecimento a máxima já é lei ou ainda é regra (posto que vale unicamente para o sujeito)? Temporalmente, a máxima não pode ser considerada lei se carece do escrutínio da razão que a reconheça como um imperativo categórico; a partir do momento que se reconhece a necessidade incondicionada da regra, então aí sim se reconhece essa regra também como uma lei moral. A insistência nesse ponto se dá por dupla razão: primeiramente, Beck está chamando a atenção para que a dicotomia entre leis e máximas é falha - há que se falar em máximas meramente (quando são materiais), máximas que são também leis (quando a máxima é a priori) e leis (que se diferem das máximas por seu caráter objetivo). Em segundo lugar, em virtude de uma tradição de comentadores dar a entender que "com a máxima faço uma lei para mim" - stricto sensu, a máxima ainda não pode nem deve ser dita uma lei no sentido forte da palavra. Como aponta Bittner (ele mesmo representante dessa corrente interpretativa), o mal-entendido a ser evitado é tomar a máxima como determinação da

${ }^{153}$ Cf. $K p V(\mathrm{~V}: 162)$. 
vontade à maneira de uma lei «gesetzartig»: podemos concluir que a máxima representa uma obrigação (livre de qualquer coerção) de um sujeito para consigo mesmo.

Retornemos à solução de Longuenesse da máxima poder ser derivada ou reconhecida como o consequente de um imperativo hipotético: parece-nos que ela faz uma interpretação muito aproximada àquela de Paton ${ }^{154}$. Em seu exemplo (2005, pp. 255-256):

\author{
(Máxima) "Enriquecerei por todos os meios seguros" \\ (Caso) Um depósito que foi confiado em segredo a mim e cuja pessoa me \\ confiou a quantia faleceu. \\ (Determinação) "Agora desejo enriquecer por todos os meios seguros. Então devo negar \\ a existência do depósito"
}

Se supuséssemos que a máxima é um princípio que diz como devermos fazer ou agir, estamos: (a) utilizando-a como uma ponte na relação de meios e fins e (b) rompendo com a definição mesma de imperativo ao introduzir o verbo "dever", de tal forma que a máxima deixa de ser um princípio para orientar o agir e passa a ser necessitante. A materialidade da máxima tem a ver com um desejo do arbítrio, mas não a um nível tão específico como aquele encontrado em um imperativo hipotético: uma inclinação a ser preguiçoso evitando sempre o cansaço é diferente da representação casuística de como evitar o cansaço. Longuenesse reconhece que no mais das vezes as máximas não vêm com a formulação "devo $x$ " ou "não devo $x$ " e argumenta que o caráter necessitante do consequente advém da maior ou menor probabilidade do termo antecedente. Para compreender esse movimento de sua argumentação, devemos relembrar as noções de imperativo hipotético.

Segundo Kant, há três tipos de princípios práticos em geral - o problema é que propriamente ele não aponta quais são. Para efeitos deste trabalho, sugerimos uma divisão segundo os pares subjetividade/objetividade e imperatividade/não-imperatividade. Consideramos que existam (1) máximas - que são subjetivas e não-imperativas; (2) preceitos - que podemos dividir

\footnotetext{
${ }^{154}$ A análise de Paton sobre as máximas parece-nos ter duas centralidades distintas de seu livro The Categorical Imperative: (a) o trecho em que aproxima a noção de máxima àquela de princípio (pp. 58-61) e (b) um segundo momento no qual as máximas são novamente abordadas como um degrau para alcançar a lei moral, mostrando um caráter de meios e fins (pp. 135-139) de tal maneira que na formulação da máxima já está embutido o imperativo hipotético. Seu exemplo (pp. 135-136) é "quando eu precisar de dinheiro, vou emprestar com a promessa de pagar de pagar de volta que não pretendo cumprir" - ora, é a formulação de um imperativo categórico: "se eu precisar de dinheiro, devo emprestá-lo (prometendo pagá-lo futuramente) mesmo sabendo que não vou honrar a promessa”. A máxima sugerida por Paton, destarte, está um grau tão específico que dificilmente se falaria em um grau universalidade ou generalidade que comporte sob si diversas outras regras práticas. Bittner critica justamente o pragmatismo que a relação meio e fim traz (2004, p. 14, nota de rodapé 8): “o uso que Paton faz de 'máxima', também para meras relações de meios e fins, passa ao largo disso [expressar o tipo de ser humano que quero ser]. Uma proposição como 'eu quero, na chuva, procurar abrigo para não me molhar' não é uma máxima, porque a prescrição está ligada apenas a um fim particular. Ela permanece puramente pragmática; se eu a sigo ou não, não tem nenhuma importância para que tipo de ser humano eu sou. Por isso, ela não será submetida a nenhum juízo moral". É curioso notar, contudo, é que Paton (1971, p.61) em sua primeira parte da análise introduz a forma da máxima do dever como uma máxima formal ou a priori, que nada tem a ver com fins desejados.
} 
em problemáticos ou reais, isto é, o preceito tal como o tomamos aqui ou é um conselho ou é um mandamento contingente da razão para atingir fins predeterminados; (3) leis - que são objetivas e imperativas posto que universais e expressam um mandamento incondicionado da razão. "Regra" é um termo usado comumente por Kant e que aponta, como visto há pouco, para múltiplos objetos: se tomarmos por base o Prefácio da Fundamentação da Metafísica dos Costumes (que oferece a oposição de regra à lei ancorada na contingencialidade da primeira e na universalidade da segunda), não seriam regras tanto a máxima quanto a maior parte dos imperativos hipotéticos? Seguindo a definição da Fundamentação da Metafísica dos Costumes (IV:414-415), o imperativo hipotético é aquele que expressa uma ação que é boa como meio para alcançar algum fim: assume a fórmula "se quero $a$, então devo fazer $b$ " - sendo, por conseguinte, descrito por Kant como problemático se diz respeito a uma intenção possível e assertórico se diz respeito a uma intenção real. Segundo Longuenesse (2005, p. 244), essa distinção se baseia especificamente na abrangência do antecedente do imperativo hipotético: os assertóricos seriam as regras de prudência, pois esse tipo de objeto é verdadeiro para todos os seres humanos (todos querem ser felizes ou todos ambicionam por sua segurança - ainda que não haja uma concordância geral e objetiva sobre o que seja a felicidade ou a segurança); os problemáticos, por sua vez, são as regras de habilidade e a força do verbo condicionante "dever" no consequente está atrelada diretamente à força da probabilidade do antecedente (quando mais certeza se tiver de $x$, mais forte será a determinação da vontade em agir de determinada forma para atingir $x$ ), o que torna a regra de habilidade bastante específica para o sujeito (em um exemplo, por mais que seja importante para alguns pais incentivarem algum dote artístico do filho, essa mesma importância pode ser nula noutros pais). Temos seguro que o imperativo hipotético é necessariamente material, pois o fim desejado determina-o completamente a posteriori na medida que só é possível estabelecer um princípio necessitante para alcançar um fim se esse fim já tiver sido anteriormente determinado. $\mathrm{O}$ imperativo categórico, para ser necessitante em qualquer situação independentemente do fim, deve ser puramente formal, destituído de qualquer materialidade, portanto a priori e independente dos desejos do arbítrio ${ }^{155}$.

Ainda que aceitemos que alguém possa querer ter como sua máxima uma formulação com o verbo "dever", contudo temos que reafirmar que a máxima não tem o caráter fortemente normativo próprio mesmo do imperativo (i.e., a máxima pode ser tomada como determinação da vontade à maneira de uma lei «gesetzartig»). Essa constatação vai ao encontro da forma comumente apresentada como máximas, por Kant, em seus exemplos - sem a normatividade embutida no verbo “dever". Em verdade, historicamente o conceito de máximas na moralística

\footnotetext{
155 Tenha-se em mente que Kant afirma na MS (VI:226): “As leis procedem da vontade; as máximas, do arbítrio”.
} 
seguiu a forma de aforismas: pequenos dizeres que expressam um tipo de sabedoria da qual se retira uma "lição" ou "princípio" para o agir ("não mentir é a melhor das políticas" 156, e. g.).

Ainda sob essa tríplice divisão dos princípios práticos, alcança-se a linha de fronteira entre o moral, o não-moral (adiaphoron) e o não-ético ${ }^{157}$ : quais seriam os princípios que interessam à ação ética? Já há elementos o suficiente para responder a essa pergunta e começar a delinear um tipo preciso de máximas: as moralmente boas.

Ainda cumpre desfazer um mal-entendido na tradição de comentadores: máximas são $a$ priori ou a posteriori? Isso seria o mesmo que dizer que máximas são formais ou materiais ${ }^{158}$ ? Vejamos dois comentadores que tratam a questão. Comecemos por Paton (1971, p. 61), que traz a definição de que "máximas empíricas são também chamadas máximas materiais: elas se referem aos fins desejados que a ação visa realizar e esses fins são a matéria da máxima. Máximas a priori são também chamadas de máximas formais. Até então, máximas formais são caracterizadas apenas negativamente: não se referem a fins desejados que a ação visa realizar”; para ele, máximas baseadas na inclinação são máximas a posteriori e as máximas são formais se não dependem do desejo de algo. Por outro lado, Bittner (2010, p. 13) afirma expressamente que "um conhecimento, que decide a regra do meu agir, será a cada vez um tipo de experiência - nem máximas nem propósitos podem ser constituídos a priori" visto que "máximas, que repousam em conhecimentos que dizem respeito à totalidade de uma vida, nascem da experiência em sentido forte: experiência de vida". Ora, estamos novamente diante de um dilema interpretativo e a questão parece poder ser resolvida desde que explicitemos claramente os termos, pois pode ser o caso de que um mesmo termo tenho significados distintos para cada autor; exploremos a questão um pouco mais a fundo antes de solvê-la, para testar se o mero aclaramento de termos é a única causa da discórdia.

O que há de comum na interpretação de ambos é a pressuposição de que a máxima é consciente, isto é, deve ser um fruto da detida reflexão e deliberação do sujeito. Eis onde começa nosso segundo bloco de problemas, o qual se organiza sob dois eixos — primeiramente, que a definição de materialidade desvela especificamente a questão de influências externas no kantismo; em um segundo ponto, considerações sobre qual o limiar da consciência do sujeito para agir por dever.

\footnotetext{
${ }^{156} \mathrm{Na}$ seção imediatamente vindoura, perceberemos que a maior parte das máximas que Kant tratará têm uma forma cristalizada em latim e foram largamente utilizados por uma tradição historiográfica da política. Podem ser tomados como aforismas de prudência ou aforismas que postulam um princípio, a depender do interesse de quem faz seu uso. ${ }^{157}$ Retome-se a argumentação da ação pode ter ou não ter interesse à moralidade. No caso de não ter caráter ético, isso pode se dar por dois casos - ser propriamente tanto um adiaphoron (uma ação irrelevante à moralidade tal como se levantar todos os dias às $7 \mathrm{~h}$ para uma corrida no parque) quanto uma ação conforme ao dever mas não por dever (tal qual a ação caridosa na qual o sujeito não pode precisar se age bem por interesse patológico ou por puro respeito ao dever). A ação ética, isto é, moralmente boa, exige um nível mínimo de consciência de se agir por respeito ao dever. ${ }^{158}$ Cf. ALLISON, 1990, p.88; PATON, 1971, p. 61.
} 
A consciência ou não-consciência do sujeito agente da máxima que o motiva a agir é outro ponto que recorrer ao próprio texto kantiano pouco ajuda: a consciência que se refere Kant não diz respeito à máxima, mas à ação moral. Remete-se à argumentação da Fundamentação da Metafísica dos Costumes na qual Kant concede que "de fato, é absolutamente impossível estabelecer com plena certeza pela experiência um único caso em que a máxima de uma ação, de resto conforme ao dever, tenha assentado unicamente em razões morais e sobre a representação de seu dever" (GMS, AA IV: 407). No mais das vezes, argumenta ele, o que age para impulsionar a vontade é o amor-de-si, mas gostamos de fazer parecer que temos causas mais nobres para nossas ações. O problema, contudo, remanesce sem solução. A consciência de agir em razão de sua máxima é determinante para a ação moral e, especialmente, eticamente boa ou virtuosa: o sujeito é, sem dúvida, o melhor juiz para avaliar a motivação de suas ações - ainda que o sujeito possa falsear para si mesmo suas reais motivações ou (o que demonstraria maior sinceridade com sua constituição antropológica) talvez nunca pudesse ter certeza dos seus reais motivos. O exemplo trazido por Beck (1971, pp. 29-32) e retrabalhado por Bittner (2004, pp. 09-10) é ilustrativo para demarcar o sensível caráter ético de suas abordagens: trata-se do observador externo que, vendo um padrão de ação relevante à moral se repetir com regularidade, postula um princípio ou uma regra de agir - por exemplo, ao perceber que a todo insulto um indivíduo $X$ reagia violentamente, o observador externo pode postular que " $X$ não tolera impunemente nenhum insulto". O postulado tem um problema capital, aponta Beck, que podemos resumir da seguinte forma: ignora-se a importância da primeira pessoa - uma etapa fundamental do processo de adoção da máxima é deixada de lado (a deliberação e a decisão) em detrimento do comportamento constatado; o coração da ética kantiana (a disposição do agir «Gesinnung»), sob a óptica do observador externo que postula, é perdido.

Em se tratando especificamente do nível de consciência das máximas, não da consciência da ação eticamente boa na qual a ciência da máxima que motiva o agir é parte sine qua non, Allison (1990, p. 90) acredita que não é necessária a consciência imediata da máxima, mas que o ser racional deve pressupor a possibilidade da consciência ainda que a posteriori. O'Neill (1989, p. 84) partilha da mesma opinião: “por outro lado, agir a partir de máximas não requer a formulação explícita, consciente ou completa da máxima. Mesmo a ação rotineira, impensada ou indecisa é agir a partir de alguma máxima”. Na afirmação de O’Neill há margem para um mal-entendido, a saber, interpretar a ação rotineira como hábito: isso expressamente é vedado por Kant em sua ética, visto que o hábito não pode nunca gerar uma ação por dever (somente conforme ao dever) — mas permitido na moral em sentido amplo. 
Por fim, resta reconhecer um anacronismo das influências contemporâneas na aproximação ao texto kantiano: a mais forte delas talvez seja a influência aristotélica de boa vida que vem travestida na forma interpretativa da máxima como "regra de vida" «Lebensregel/pattern of life». Por trás de algumas análises ${ }^{159}$, reconhece-se uma noção bastante próxima de "vida boa": certamente o uso moral de máximas, no todo da doutrina dos costumes, não concernia a essa concepção - não faz sentido uma interpretação na Doutrina do Direito das máximas que podem propiciar a coexistência do arbítrio de um ao arbítrio de todos os demais serem tomadas como um tipo de "boa vida".

\subsubsection{Máximas políticas: harmonizando a política com a moral}

Kant fala do caráter preliminarmente pedagógico da ética (MS, AA VI:406-407) no sistema dos costumes e talvez esse método de exposição utilizado na Fundamentação da Metafísica dos Costumes, sua obra moral mais difundida, tenha contribuído para uma leitura acentuadamente ética das máximas que concordam com o imperativo categórico e, em razão disso, tais máximas são reconhecidas como leis universais. Esperamos haver estabelecido em nossa investigação nos passos dados até aqui que a Fundamentação da Metafísica dos Costumes e a Metafísica dos Costumes se referem a um sistema universal dos costumes ou, noutras palavras, à moralidade em sentido amplo. Contudo, se o princípio supremo da moralidade é um só, o tratamento que se dispensa às máximas não pode ser cego em função do tipo de obrigação a que se ligam: faz sentido falar em "máximas éticas" ou "máximas jurídicas" — estas últimas podem dizer respeito tanto à ação do sujeito (e nisso se assemelham às máximas éticas porque são também um ato da liberdade do arbítrio) quanto a ação de elementos específicos (se compreendermos as leis ou qualquer outra normatividade oficial que ordena ou recomenda como portadoras de uma pretensão). As máximas relativas à liberdade do arbítrio não podem ser postuladas por um observador; contudo a máxima que guia a pretensão de uma atitude do governo (traduzida em um ato jurídico de caráter normativo) tem de ser postulada. O mesmo se passa com as máximas políticas: é necessário poder extrair a máxima que orienta a pretensão de outro sujeito — devemos esquecer a recomendação de Beck e Bittner que máximas não podem ser postuladas, sob pena de não harmonizar a moralidade consigo mesma.

Nesse sentido, Kant oferece n'À paz perpétua alguns exemplos diretos e bastante precisos de quais são as máximas políticas recorrentes:

1. "sedes astutos como as serpentes" (VIII:370);

2. Fac et excusa - faça e dissimule (VIII:374);

3. Si fecisti nega - se fez, negue (VIII:374);

${ }^{159}$ Cf. BITTNER, 2004, pp. 13-14; HÖFFE, 2005, p. 204. 
4. Divide et impera - desune e impere (VIII: 374-375);

5. "Se um destes Estados prometeu algo ao outro: seja préstimo de auxílios, cessão de certas terras, ou subsídios e similares, pergunta-se se ele pode desfazer-se do empenho da palavra em um caso de que dependa a salvação do Estado, enquanto quer que seja considerado em uma dupla pessoa, primeiramente como soberano, já que ele não tem que responder a ninguém em seu Estado; depois, porém, em contra-partida, simplesmente como funcionário do Estado supremo que tem de prestar contas ao Estado: de onde se tira a conclusão que, daquilo a que ele se obrigou na primeira qualidade, estará dispensado na segunda".

6. "Se uma potência cresceu até um tamanho temível (potentia tremenda) suscita a apreensão: pode-se admitir que ela quererá também oprimir, porque ela pode, e isso dá aos menos poderosos um direito de ataque (unido) a ela, mesmo sem ofensa procedente?" - variação do divide et impera.

7. "Se um Estado menor, por sua situação, separa a continuidade de um maior, que é, porém, necessária a este para sua conservação, não está este autorizado a subjugar aquele e uni-lo ao seu?"

Alguns dos exemplos de máximas políticas oferecidas pelo filósofo, especialmente nos exemplos de um a quatro, são assemelhadas a aforismas dos quais se deve deduzir alguma aprendizagem de prudência que inste a agir de uma dada maneira (são máximas de prudência política); outras vezes, como parece ser o caso dos exemplos cinco a sete, fica a nosso cargo extrair e postular a máxima que orienta o agir dos Estados. Nossa interpretação é que, na política e no direito, é necessário alargar a definição de máximas daquela tradicionalmente trabalhada a partir da Fundamentação da Metafísica dos Costumes e da Crítica da Razão Prática: primeiramente, em direção à compreensão de máxima como pretensão; em segundo lugar, que é lícito o ato de tomar consciência de máximas (pretensões) políticas - essa licitude está lastreada no fato que esse é um ato da faculdade de julgar e não entra em choque com o dever de considerar a humanidade do outro sempre ao mesmo tempo como fim: o Estado e a legislação não têm nenhuma humanidade senão aquela das pessoas que exercem o poder (enquanto pessoas públicas) e que está resguardada noutra seara (enquanto pessoas privadas).

E, assim, havemo-nos com a tese que subjaz à nossa abordagem das máximas: afastando o tratamento que foi dado pela tradição de comentadores às máximas, desvela-se uma possibilidade interpretativa interessante - que o esforço de consciência das máximas políticas e jurídicas contribuem para o progresso do gênero humano no tocante à cultura e que os dispositivos que contribuem ativamente para isso são a fórmula e o princípio transcendentais do direito público.

Poderei, pois, admitir que, dado o constante progresso do gênero humano no tocante à cultura, enquanto seu fim natural, importa também concebê-lo em progresso para o melhor, no que respeita ao fim moral do seu ser, e que este progresso foi por vezes interrompido, mas jamais cessará. (TP, AA VIII:308-309)

Tal como expusemos anteriormente, o Estado pode ser abordado sob duas perspectivas filosóficas distintas no pensamento kantiano: pela via do direito político (portanto do idealismo político que compõe o direito público enquanto direito racional) ou pela via da filosofia da história. A abordagem à luz da filosofia da história, isto é, desviar o olhar do agir do sujeito imerso em um 
grupo rumo ao todo da espécie, permite esclarecer por que as máximas importam e foram tomadas como elemento privilegiado do debate público. Nessa seara, pode-se dizer seguramente que a natureza quer que o ser humano desenvolva suas disposições racionais - esse é o pressuposto mais fundamental que permite abrir as portas para adentrar na questão do aperfeiçoamento político como causado e garantido pela natureza (na medida que o direito público é um mesmo mecanismo da natureza) e o chamado "argumento teleológico" da história. Sobre a questão do desenvolvimento da disposição racional dos homens, vemos uma articulação entre duas proposições da Ideia universal de um ponto de vista cosmopolita:

A natureza quis que o homem tirasse inteiramente de si tudo o que ultrapassa a ordenação mecânica de sua existência animal e que não participasse de nenhuma felicidade ou perfeição senão daquela que ele proporciona a si mesmo, livre do instinto, por meio da própria razão $\left(\mathrm{IaG}, 3^{\mathrm{a}}\right.$ proposição)

No homem (única criatura racional sobre a Terra) aquelas disposições naturais que estão voltadas para o uso de sua razão devem desenvolver-se completamente apenas na espécie e não no indivíduo" ( $\mathrm{IaG}, 2^{\mathrm{a}}$ proposição).

Invertemos a ordem dos artigos propositalmente, a fim de mostrar um crescendo no movimento kantiano - que o homem em indivíduo deve apoiar-se na sua razão para dela extrair tudo o que necessitasse e, inclusive, sua felicidade; enfim, no todo da espécie. Isso faz lembrar a argumentação da I Seção da Fundamentação da Metafísica dos Costumes na qual Kant retorna à natureza para exortar o uso prático da razão ou, melhor dizendo, a boa-vontade: se a natureza quisesse que houvesse meramente uma conservação básica da espécie e a felicidade entendida enquanto gozo dos prazeres, teria sido mais eficaz se não tivesse dotado o homem da razão e o tivesse restringido ao mero instinto; mas dotou o homem da capacidade racional (e, para além disso, não uma mera racionalidade instrumental e sim uma razão com uso prático). A conclusão não pode ser outra além do homem ser destinado a utilizar sua razão para conservar-se melhor e que a felicidade é, no homem, algo além do prazer e desprazer. Ora, ao passo que o terceiro artigo centra-se no homem enquanto indivíduo, o segundo artigo alarga o escopo do desenvolvimento das disposições racionais ao afirmar que só encontram plenitude enquanto em espécie: a espécie é mais duradoura que o homem individual, portanto a permanência dos ganhos da razão é mais segura e permanente na espécie como todo.

O meio que a natureza encontra para compelir o homem a cumprir seus planos são as disposições antagônicas (na quarta proposição da Ideia é referido como "insociável sociabilidade" - que não trataremos agora em pormenores porque pretendemos tratá-la na próxima seção): ao cabo, Kant refere-se às disposições antagônicas externas do arbítrio. Conforme apontamos anteriormente no início desta investigação, cabe ao direito debruçar-se no campo da liberdade externa do arbítrio: é o direito, portanto, o meio que a natureza espera que a própria razão encontre 
para desenvolver a conservação da espécie. É no ambiente da realidade empírica em que a soberania coincide na pessoa do chefe de governo que a consciência das máximas políticojurídicas que estão por trás das pretensões das ações do governo e dos demais atores políticos desvela sua força reformadora: pelo debate público dos princípios que regem as ações, abre-se a reflexão sobre o tipo de sociedade que se deseja.

\subsection{O uso público da razão}

A autonomia em sua expressão política deve ser entendida como a capacidade de fazer uso público da razão. É mais complexa no ponto de vista de aplicação, portanto, que as expressões anteriores - a autonomia ética (do sujeito se tomar como autor imediato das leis por sua vontade que legisla universalmente) e a autonomia jurídica (de se tomar também como como autor mediato da obrigatoriedade e coerção da lei jurídica justamente em virtude dessa lei ser fruto de uma necessária representatividade política).

Se a política é necessariamente estabelecimento de um espaço público, a publicidade recebe um teor político. O direito de falar publicamente serve como medida da liberdade de um povo; quanto mais reduzido ao silêncio, menor sua liberdade e seu progresso moral, menor sua humanidade, qualquer que sejam os benefícios de bem-estar que possam ser promovidos ${ }^{160}$.

\subsubsection{A fórmula e o princípio transcendentais do direito}

Eis o dispositivo pelo qual pode-se dar o esclarecimento público: a fórmula transcendental ${ }^{161}$ do direito público — um procedimento destinado a aferir a justiça ou injustiça

\footnotetext{
160 Zingano, 1988, p. 284.

161 Zingano (1988, p. 285) também estranha a denominação transcendental deste princípio, afirmando-o como metafísico: “Como a moral só é, ou seja, só recebe seu ser especial, quando confuta sua inanidade, portanto refrata-se politicamente, Kant denomina esse princípio positivo da publicidade um princípio transcendental, ainda que, se quisermos ser rigorosos, ele é um princípio metafísico". "Um princípio transcendental é aquele pelo qual é representada a priori a condição universal, sob a qual apenas as coisas podem ser objetos de nosso conhecimento em geral. Em contrapartida, um princípio chama-se metafísico se representa a priori a condição sob a qual somente os objetos, cujo conceito tem de ser dado empiricamente, podem ainda ser determinados a priori. Assim é transcendental o princípio do conhecimento dos corpos como substâncias e como substâncias suscetíveis de mudança, se com isso se quer dizer que a sua mudança tem que ter uma causa; é porém metafísico se com isso se significar que a mudança tem que ter uma causa exterior. A razão é que, no primeiro caso, para se conhecer a proposição a priori, o corpo só pode ser pensado mediante predicados ontológicos (conceitos do entendimento puros), por exemplo como substância; porém, no segundo, o conceito empírico de um corpo (como de uma coisa que se move no espaço) tem que ser colocado como princípio dessa proposição, embora então possa ser compreendido completamente $a$ priori que o último predicado (do movimento somente mediante causas externas) convém ao corpo. Assim, como já a seguir vou mostrar, o princípio de conformidade a fins da natureza (na multiplicidade das suas leis empíricas) é um princípio transcendental. Na verdade o conceito dos objetos, na medida em que os pensamos existindo sob este princípio, é apenas o conceito puro de objetos do conhecimento de experiência possível em geral e nada contém de empírico. Pelo contrário, o princípio da conformidade a fins prática, que tem de ser pensado na ideia da determinação de uma vontade livre, seria um princípio metafísico, porque o conceito de uma faculdade de apetição, enquanto conceito
} 
das intenções por trás das ações dos atores políticos. A noção de justiça (que nada mais é do que conseguir angariar apoio público à uma intenção) já deixa claro que a harmonização da política com a moral é realizada através de um "teste" à semelhança do imperativo categórico:

Todas as ações relativas ao direito de outros homens cuja máxima não se conciliar com a publicidade são injustas (ZeF, AA VIII:381)

Vez que se abstraia de toda a matéria no direito público, resta a forma da publicidade e toda pretensão jurídica tem em si a forma da publicidade (pois seria contraditório pensar uma lei que não fosse seguida por ninguém porque seu conteúdo é secreto - é próprio da norma jurídica a vinculação pública universal $)^{162}$. Kant faz uma diferenciação entre a fórmula e o princípio transcendentais do direito público: o ponto de passagem reside justamente nos efeitos esperados a partir da publicidade. Reza o princípio transcendental da publicidade que:

Todas as máximas que necessitam da publicidade (para não malograr em seu fim) concordam com o direito e a política unidos (ZeF, AA VIII:386)

A diferença entre a fórmula transcendental e o princípio transcendental do direito público pode ser posta com alusão a uma analogia com a conformidade e o motivo de uma ação ao dever: a fórmula transcendental pode garantir a conformidade das pretensões ao direito público, vez que chancela como justa qualquer tipo de lei jurídica: sejam leis proibitivas, que propõem como dever a omissão de certas ações; leis prescritivas, que propõem como dever a efetivação de determinadas ações; bem como leis permissivas ${ }^{163}$, aquelas que permitem ações que não colidem com dever nenhum. O princípio transcendental do direito público, por sua vez, preocupa-se certa medida com o motivo da ação na medida que somente a publicidade pode coerir adesão pública e fazer ter êxito a pretensão jurídica; o fim almejado só pode ser concretizado, portanto, com a publicidade ${ }^{164}$.

de uma vontade, tem de ser dado empiricamente (não pertence aos predicados transcendentais). Contudo, ambos os princípios não são empíricos, mas sim princípios a priori. É que não é necessária uma ulterior experiência para a ligação do predicado com o conceito empírico do sujeito dos seus juízos, mas, pelo contrário, tal ligação pode ser compreendida completamente a priori" (KU, V:181-182.15-09 - grifos nossos). Acredito que a minha resposta deva ir nesse sentido. Primeiramente que (1) o público pode ser pensado a priori sem qualquer prejuízo na aplicação do princípio proposto independentemente de como se constitua historicamente. Ademais, que (2) não é necessário uma experiência ulterior que o confirme, mas é justamente o contrário — posso entender a priori no sentido desse princípio visar influir na experiência possível antes mesmo de eu considerá-la. Noutras palavras, o transcendental não é por se referir às condições mas justamente por normatizar de antemão. Para usar uma palavra jurídica, o princípio "constrange" a experiência antes mesmo de se dirigir a ela para confirmar sua validade.

162 Cf. ZeF, AA VIII:381.

163 Noutras palavras, leis permissivas seriam leis que "obrigam a ações a que ninguém está obrigado" — à primeira vista um contrassenso do ponto de vista do direito positivo, mas conceito útil para pensar o direito natural. A ocorrência de leis permissivas e sua importância para a ciência do direito, isto é, para a doutrina do direito natural, se dá n’À paz perpétua (cf. ZeF, AA VIII:347) e na Metafísica dos Costumes (cf. MS, AA VI:223). Não nos aprofundaremos no conceito por não considerá-lo essencial ao seguimento da argumentação.

${ }^{164}$ A fim de dar materialidade à diferenciação, podemos pensar a fórmula transcendental como referindo-se a pretensões amplas: é um termômetro para toda pretensão de qualquer ator político; referente ao ato legislativo, aplicase a todas as leis. O princípio transcendental do direito público aplica-se a determinadas intenções e pode ser interpretado como a vontade do legislador em induzir a ação pública dos cidadãos por intenções moralmente boas — é o caso, por exemplo, de uma lei que institua a coleta seletiva ou estimule uma mudança de um mau hábito da 


\subsubsection{O público}

Nosso interesse nesta parte da argumentação é demonstrar que o princípio transcendental do direito público exige um fórum próprio para realizar o procedimento de teste da máxima política: uma esfera pública onde se possa confessar e discutir publicamente as máximas. Para pensar uma esfera pública ideal, isto é, para alcançar a ideia de uma esfera pública tal como ela deva ser, creio ser necessário dois passos anteriores - primeiramente, uma retomada histórica da noção de público e a inversão desses conceitos a que Kant procede no seu escrito Resposta à pergunta: o que é o Esclarecimento?; em um segundo momento, trata-se de uma "especificidade kantiana": a contextualização histórica que permite entender a razão da esfera pública, para Kant, ser restrita ao público leitor e por que posso afirmar que essa seja uma condição contingente. Seus textos políticos tinham uma inegável conectividade com seu tempo. Pelo desenvolvimento geral da filosofia kantiana, acredito que não seja exagerada a leitura de que pela via do esclarecimento a tendência seria desse público crescer e a esfera pública alargar-se mais e mais.

Pretendemos fazer uma reconstrução da ideia de "público" enquanto adjetivo, isto é, ligada à tradição jurídica; em seguida, trataremos do "público" entendido enquanto substantivo. Acreditamos que o conceito de esfera pública seja um problema teórico-prático por excelência: é pela esfera pública que a política, enquanto doutrina executiva do direito, faz a ponte entre a metafísica do direito e o problema político. A resposta que esta dissertação procura, isto é, o fiocondutor que liga a ética ao direito e à política (caracterizando uma unidade na moral) só se realiza no ambiente público: tal como na ética, onde as máximas devem ser universalizadas para fracassarem ou alçarem o "status" de lei prática, veremos que na política as máximas devem ser universalizadas de maneira própria (pela via do princípio universal do direito) para serem consideradas justas ou injustas e, consequentemente, por meio de uma pretensão legítima ou ilegítima.

Habermas ${ }^{165}$ chama a atenção para diversas acepções comuns que o adjetivo "público" é geralmente ligado cotidianamente, sem contar os diversos usos que as ciências humanas atuais (como o direito, a política ou a sociologia) fazem dessa noção — cada uma dessas ciências trabalha, é verdade, com uma definição mais precisa que o uso coloquial, mas nem por isso são definições que expressam sempre o mesmo. A noção de "público", seja como adjetivo ou substantivo, tem acepções bastantes distintas: relativamente à acessibilidade, à propriedade, ao

população para um bom hábito: tais programas não alcançariam com sucesso seu intento se somente se acenasse aos cidadãos com uma coerção, mas para se cumprirem necessitam de um tipo de esclarecimento público, isto é, necessitam convencer por razões os cidadãos a aderirem à intenção do legislador.

165 Cf. HABERMAS, 2011. 
Estado, a uma parte da sociedade civil ou sua pretensa totalidade (a opinião pública), senão mesmo a um grupo relativamente amplo e cooperativo de pessoas. Frente a isso, creio ser evidente a legitimidade do esforço em precisar aqui as noções de público e privado com as quais trabalharemos. Ainda de acordo com Habermas, interessa aqui o fato de que na cultura ocidental foi cunhada a significação de público e privado como herança do direito romano, que por sua vez tomou para si as noções de público e privado dos gregos. É produtivo retomar dois caracteres essenciais dessas noções na sociedade grega: o caráter cooperativo do domínio público que se assentava em dar razões, arrazoar, discutir mediante razões nas assembleias e a ligação à ideia do público como "aberto", isto é, pode-se fazer a oposição entre a vida pública (bios politikos) e a vida privada (oikos) - atentando-se o público é relativo ao político, discutido abertamente nas praças públicas, e o privado é relativo à esfera da casa. Os romanos mantiveram a ideia do público como "aberto", especialmente cristalizada e repassada à tradição ocidental pela via do direito romano. É próprio da linguagem coloquial que atravessou a Idade Média até os dias de hoje de entender o público como aquilo que está além das paredes de casa, de interesses intramuros, que remete ao interesse geral para a coletividade. Foi de Cícero a distinção entre Direito Público (ius publicum), como aquele garantido por instituições dotadas de poder público (potestas publica) e Direito Privado (ius privatum) como relativo aos acordos de vontades havidos particularmente.

Kant inverte as noções de público e privado no seu Resposta à pergunta: que é o Esclarecimento? Essas noções são readequadas por ele em função da audiência ${ }^{166}$ a que se destinam. O uso privado da razão será aquele uso feito por pessoas públicas no exercício de suas funções públicas; o uso público da razão, o uso que se fará ao se dirigir (enquanto Gelehrter) ao público letrado. Voltarei a esse ponto adiante, por ora interessa enfatizar que o uso público da razão se faz exclusivamente pela escrita a um público, portanto, a um público restrito. O próximo passo é responder a questão "por quê a um público restrito"?

Pretendo agora reconstruir brevemente a gênese de esfera pública no interior da filosofia kantiana. Para tanto, devo sair do campo dos textos políticos e regressar à Crítica da Razão Pura porque é ali que acredito estar a referência mais emblemática do que seja uma esfera pública para Kant:

A razão tem de submeter-se à crítica em todos os seus empreendimentos e não pode compreender a liberdade desta. (...) Nessa liberdade está baseada a própria existência da razão, que não tem uma autoridade ditatorial e cuja sentença, pelo contrário, nunca é outra senão o livre consenso dos cidadãos. ${ }^{167}$

\footnotetext{
166 O'NEILL, O. Constructions of reason. Cambridge: Cambridge University Press, 2000, pp. 32-34

${ }^{167} \mathrm{KrV}, \mathrm{B} 766$.
} 
É a razão em seu âmbito público (e não a força) que faz o direito, contudo fica claro que a razão por si mesma não tem uma autoridade ditatorial (se tivesse tal autoridade, seria o mesmo que justificar o dogmatismo e, consequentemente, esvaziar a própria tarefa crítica). No tribunal da crítica, a razão é ré e o ao mesmo tempo a juíza que prolata a sentença e, se assim não o fosse, a tarefa crítica seria heterônoma e ilegítima - atente-se para a sentença: não é monocrática, mas resultado de um debate aberto e justamente isso lhe garante legitimidade. É resultado do livre consenso dos cidadãos. Eis o mecanismo da esfera pública: o debate crítico, aberto, cuja verdade não repousa em um dogmatismo fechado - senão em um construtivismo do conhecimento ${ }^{168}$.

\subsubsection{Contextualização: o público empírico}

O escrito Resposta à pergunta: que é o Esclarecimento? deve ser recontextualizado em função de nossos propósitos nesta investigação em dois pontos: por apontar politicamente o que se deve compreender por autonomia, portanto aponta para a expressão política da autonomia, ao mesmo tempo que faz o esforço em consolidar uma espécie de espaço público de debates (meio pelo qual se exerce a maioridade cidadã preconizada no texto). A pergunta a ser feita neste momento é dúplice: qual o público que se exige para a autonomia política e quem era o público a quem Kant se referia ao defender a liberdade de debate público. Haveria alguma identificação entre as duas respostas? Nesta seção, trata-se de responder a segunda pergunta — pelo público histórico.

O seguinte trecho ainda do Resposta à pergunta pode dar pistas sobre quem era esse público:

Pelo uso público da razão, refiro-me ao uso que qualquer um pode fazer dela enquanto Gelehrter (WA, AA VIII:37).

Mais ainda, podemos ler pouco mais adiante desse trecho que esse público é o que Kant considera um "público no sentido verdadeiro da palavra" ${ }^{169}$. O uso da palavra alemã Gelehrter ajuda a colocar os termos da questão na medida que suscita a indagação sobre quem, afinal, é esse público tão específico?

Segundo Laursen ${ }^{170}$, a noção de público (entendido enquanto substantivo) começava a se formar na época em que Kant escrevia. É curioso notar que esse movimento vem atrelado ao

\footnotetext{
${ }^{168} \mathrm{O}$ construtivismo crítico do conhecimento é a diferença, por exemplo, entre uma doutrina fechada com pretensões científicas e a nova ciência newtoniana, aberta, cooperativa, sob a qual a tarefa crítica kantiana punha-se sob proteção. ${ }^{169}$ Artur Morão traduz como "na qualidade de um erudito $<$ Gelehrter $>$ que se dirige por escrito a um público em entendimento genuíno".

${ }^{170}$ LAURSEN, J. C. "The subversive Kant: the vocabulary of public and publicity" (In: Political Theory, vol. 14, $\mathrm{n}^{\circ}$ 4, 1986).
} 
desenvolvimento da concepção jurídica do termo (empregada enquanto adjetivo), pois o público a que se refere o direito mantém a ligação ao "aberto" (öffentlich) do direito romano. No séc. XVIII, com a invenção da prensa, surgiam os primeiros jornais e as contribuições eram enviadas por intelectuais — porém abertas ao escrutínio do público leitor em geral. A palavra latina publicum é apropriada pelo alemão para designar o substantivo (das Publikum) e convive com sua tradução germânica enquanto adjetivo (öffentlich).

Ainda na Resposta à pergunta, o sentido de público é mais amplo e pode ser reconstruído pelos exemplos que Kant dá no próprio texto: seu público era constituído de serventes civis ${ }^{171}$ (como ele mesmo) e por burgueses ${ }^{172}$. Era a essas pessoas que a possibilidade de fazer uso público e uso privado da razão se dirigia, pois eram essas pessoas que se encontravam em posição de promover o Esclarecimento. Uma categoria especial, os escritores da corte ${ }^{173}$, não estavam englobados no público que interessava a Kant: não eram esclarecedores (Aufklärer) no sentido forte da palavra, pois sua dependência era direta ao príncipe - não às instituições do Estado. Talvez seja essa a pista para interpretar a afirmação kantiana que o público formado pelos Gelehrter é o público no verdadeiro sentido da palavra: essa distinção lembra muito a distinção entre cidadãos ativos e cidadãos passivos, cuja centralidade reside na independência em relação a outrem para sobreviver. O público dos serventes civis e burgueses era o público que precisava ser protegido a fim de expressar sua opinião e continuar o processo do esclarecimento; os escritores livres, por ironia, eram aqueles mais dependentes em agradar ao príncipe e, por essa razão, menos comprometidos com a causa do esclarecimento ${ }^{174}$.

Toda esta exposição teve como finalidade contextualizar a esfera pública a qual Kant se dirigia, agora cabe o esforço de depurar os elementos empíricos pontuais e extrair daí conceitos

\footnotetext{
${ }^{171}$ Beamtem, isto é, as pessoas diretamente dependentes do Estado para a sua sobrevivência.

172 Bürger, isto é, especificamente as pessoas independentes do Estado para sua sobrevivência e que pagavam impostos.

173 "Freie Schriftsteller".

${ }^{174}$ Não cabe aprofundamento na questão histórica, sob risco de desvirtuar a argumentação principal, contudo deve-se considerar o momento político em que Kant escrevia: com a morte de Frederico I, assume seu sobrinho Frederico Guilherme e nessa transição o "estado de direito" garantido por Frederico I é abandonado em favor do absolutismo. Através de um edito, Frederico Guilherme atinge com a censura prévia três faculdades (Medicina, Direito e Filosofia). Kant traz a público o princípio transcendental do direito público n'À paz perpétua: de publicizar as intenções como forma de teste para conferir se as intenções eram conformes ao direito ou não. Ainda n'À paz perpétua, o artigo secreto recomenda ao rei consultar secretamente os filósofos sobre os assuntos de Estado. A argumentação do Conflito das Faculdades segue uma linha parecida, com a diferença argumentativa que os escritos da Faculdade de Filosofia não chegariam ao grande público dada sua complexidade e, portanto, sua impopularidade (se não se restringisse ao público estritamente filosófico, tais materiais produzidos pela Faculdade de Filosofia somente serviriam de material para os doutrinadores das outras Faculdades). Seria útil ao rei que se deixasse os filósofos debaterem livremente, pois isso livraria o rei de ter de consultar-se diretamente com eles acerca de assuntos de Estado. Vê-se que, como último recurso para fazer o esclarecimento sobreviver à censura, Kant fecha o público em um sentido muito estrito: de "doutrinador" - aos professores das Faculdades, um público estritamente acadêmico; contudo, mantém-se a necessidade de publicizar o pensamento a fim de que as ciências e o conhecimento não murchem e morram: ao cabo, é no debate público que se assenta o desenvolvimento do conhecimento; não há outra via.
} 
filosóficos para se trabalhar. Em primeiro lugar, cabe dizer que o esforço de pensar a ideia de uma esfera pública encontra seu lugar nesta pesquisa pelo enunciado do princípio transcendental do direito: "são injustas todas as ações que se referem ao direito de outros homens cujas máximas não se harmonizem com a publicidade". A partir desse princípio, fica mais clara a divisão (ou talvez fosse mais adequado falar em "alargamento") da autonomia ética para a autonomia jurídica ${ }^{175}$ : o consentimento jurídico-político não pode se dar de maneira solitária, mas em conjunto - via esfera pública se debate a criação das leis e, eventualmente, debate-se a conveniência da lei positiva já criada. A publicidade, portanto, deve ser o alicerce sobre o qual repousem todas as ações relativas ao direito público: seja pelo lado das forças sociais (o exemplo kantiano n'À paz perpétua é o grupo de revoltosos que deseja a revolução - sua máxima seria incompatível com o direito público e, portanto, sua ação injusta de antemão) ou pelo lado do governo (não pode ser justo o tribunal de exceção - aquele cujas sentenças não são embasadas em leis amplamente publicizadas, senão em leis extraordinárias, pois fere o princípio de igualdade jurídica).

Outros textos menores reafirmam o vínculo entre o público e a autonomia em sentido político-jurídico. O texto d'o que é Esclarecimento define empiricamente (pontualmente segundo a sociedade na qual o autor está inserido) qual é a esfera pública e apresenta aquilo a que nos referimos como autonomia em sua forma mais rudimentar: a saída da tutelagem, isto é, a saída “[d]a incapacidade de se servir do entendimento sem a orientação de outrem" ${ }^{176}$. Vemos, pois, o conceito de máxima podendo ser usado pelo indivíduo (moralmente) ainda que sob uma perspectiva de grupo (a consideração pela comunidade ética), como também podendo ser utilizado por grupos maiores e mesmo o governo (a representatividade, na qual a ausência torna as formas de governo não-formas, tem mesmo como plano de fundo a existência de uma ou mais casas representativas nos quais os debates entre representantes possam ser ouvidos e debatidos publicizados, ainda que institucionalmente). Há que se reconhecer, então, níveis de público ou diferentes esferas públicas. Mesmo o acordo mais fundamental entre os homens, o contrato originário para formar o estado civil, pressupõe a ideia de uma deliberação pré-pacto entre os participantes - a publicidade e a noção de público estão na gênese mesmo da ideia do Estado.

A ideia (no sentido próprio kantiano) de uma esfera pública aponta para a figura de um mundo hipotético de "seres suprassensíveis" $" 177$ no qual os sujeitos são esclarecidos, gozam de isonomia entre si (sem relações de dependência ou hipossuficiência) de maneira que respeitem a si próprios, aos outros e a cada um de seus fins particulares.

\footnotetext{
${ }^{175}$ Aquela expressa em n'À paz perpétua como “a faculdade de não obedecer a quaisquer leis externas senão enquanto lhes pude dar meu consentimento" (ZeF, AA VIII:B21).

176 WA, AA VIII: 35.

${ }^{177}$ Cf. ZeF, AA VIII:351.
} 


\subsubsection{O público "a priori” da teoria}

Estritamente, o público a que se refere o princípio transcendental do direito é um público a priori. A fórmula e o princípio transcendentais do direito público tratam das condições de possibilidade da harmonia da política com a moral ou, o mesmo, de uma política-moral: se a publicidade é a forma dessa condição, a matéria deve ser pensada como o público que aplica o princípio - a política kantiana conforma também uma metafísica e, portanto, trabalha a partir de proposições e conceitos puramente a priori; a questão agora é definir a forma desse público.

O texto mesmo d'À paz perpétua dá uma conformação material inicial a esse público: segundo o primeiro artigo definitivo para a paz perpétua, esse público deve ser formado por cidadãos republicanos, isto é, ao menos republicanamente orientados em sua disposição.

Outros textos dão noção de como deve ser esse público. Apesar de trazer considerações sobre um público específico, o opúsculo $O$ que é o Esclarecimento também traz noções decisivas para compor o público a priori: "é perfeitamente possível que um público a si mesmo se esclareça. Mais ainda, é quase inevitável, se para tal lhe for dada liberdade" ${ }^{178}$. A liberdade que se necessita para esclarecer-se é a "liberdade da pena": a liberdade de posicionar-se publicamente mediante razões. Nesse sentido, Eric Weil ${ }^{179}$ se refere ao cidadão pensante e descreve precisamente seus atributos: esse cidadão tem como a arma mais decisiva a crítica, está imerso no espírito do Esclarecimento e utiliza sua razão publicamente - o cidadão pensante será o bom cidadão porque julga, porque é guiado por um fim e porque se pronuncia, portanto. Agir mediante razões é a característica mais marcante desse público: a necessidade de formar consciência das máximas do outro (postular os princípios que regem a intenção do outro se ele não declarar publicamente suas intenções) e ter a consciência de suas próprias máximas para confessá-las é um agir sob razões e não um agir patológico ou meramente reativo. Diversos autores ${ }^{180}$ remetem à noção de sensus communis:

1. pensar por si;

2. pensar tomando para si o ponto de vista de todos os outros;

3. pensar sempre de maneira consistente.

Pensar por si é a mais imediata realização do lema do Esclarecimento "sapere aude!"; o passo mais básico em vencer a dependência de outrem. A dificuldade cresce conforme avançamos para as condições seguintes: no segundo passo, o que está em jogo não é desenvolver a capacidade

\footnotetext{
178 WA, AA VIII:36.

${ }^{179}$ WEIL, 1962, p. 16-17.

180 O’NEILL, 1989, pp. 42-49; NOUR, 2004, pp. 79-81.
} 
de empatia (de se colocar no lugar do outro - pois, se assim fosse, seria meramente prudencial e com o mesmo valor da regra de ouro "não faça a outro o que não quer que façam a você" e não haveria moralidade envolvida), mas reconhecer o ponto de vista da comunidade, isto é, não meramente intentar se por no lugar do outro (seria certamente impossível percorrer a totalidade matemática dos indivíduos um a um); reconhecer o ponto de vista da comunidade tem a ver com juízos morais, com o uso puro da razão prática e da faculdade de julgar. O discurso da comunidade deve é o discurso da razão, visto que o corpo social não tem materialidade própria (e a as disposições antagônicas dos indivíduos acabam por anularem-se umas às outras no cômputo geral) resta a forma racional. O discurso da comunidade é arrazoado, portanto; forma-se pelo embate razões e contrarrazões, em um discurso logicamente ordenado e que se submete à crítica pública. Enfim, é “pensar de maneira consistente” conforme enuncia O’Neill: em uma tentativa de definição singela, é ser sincero para consigo e para com os demais quando se adentra em um debate — refere-se às boas práticas para construir algo novo em cooperação mútua para o bem comum. E não seria “bem comum” uma forma de se referir à república «gemeines Wesen»? Enfim, voltamos ao início para reafirmá-lo: o cidadão do público a priori que a política e o direito público lidam é ninguém menos que o cidadão republicano.

\subsection{A república como um reino dos fins?}

O’Neill ${ }^{181}$ endossa que o imperativo categórico tem papel fundamental na construção de uma sociedade político-jurídica: o caminho no qual se dá o debate deve ser via máximas. Certamente está pensando no conceito de reino dos fins com viés político: o reino dos fins é inserido como um adendo à formulação da autonomia, mas na verdade parece ser a noção central da terceira formulação. Não há propriamente um enunciado canônico para ele ${ }^{182}$, visto que é citado diversas vezes de maneiras diferentes e, nesse sentido, Rawls fala em mais de dez formulações possíveis dentro da Fundamentação, mas sua a essência pode ser enunciada assim: "age como se fosse sempre um membro legislador através de suas máximas em um reino dos fins universal”.

Na Fundamentação, Kant utiliza-se da palavra reino (Reich) para referir-se ao mundo inteligível moral e seguimos na direção que, justamente a partir daí, propicia-se uma nova leitura política liberal-democrática do reino dos fins - leitura esta que Katrin Flikschuh define como "paralelos feitos entre a exposição kantiana de agentes legislando a lei moral para si mesmos no reino dos fins e o ideal de John Rawls de uma sociedade bem ordenada na qual uma comunidade

\footnotetext{
181 O’NEILL, 1989, p. 44.

182 Sobre o problema do enunciado canônico, cf. GMS, AA IV:433-438. Adicionalmente, PATON, 1971, pp. 129-132 e p. 185; O'NEIL, 1989, p.127; RAWLS, 2005, pp. 233-243.
} 
de colegisladores alcançam um acordo razoável de princípios de justiça" ${ }^{183}$. A palavra reino conduz a uma ambiguidade natural ${ }^{184}$ : de um lado, faz a referência a um reino político enquanto Estado juridicamente constituído; por outro lado, faz referência também ao "reino de Deus".

A chave para compreender a mudança de interpretação sugerida por Rawls é explicitada por ele mesmo no excerto a seguir:

O que traduz melhor as palavras de Kant "zuzammenstimmen ... zu einem möglichen Reiche der Zwecke" não é "harmonizar-se" (Paton), mas "coerir". Acredito que assim esteja mais próximo ao pensamento de Kant, segundo o qual não há um reino dos fins já dado, por assim dizer, com o qual nossa ação legisladora deva de alguma maneira se harmonizar. Antes, nossa ação legisladora, conforme seguimos de maneira inteligente e conscienciosa os princípios da razão prática (procedimentalmente representados pelo procedimento do IC), constitui, ou constrói, a lei moral pública para um reino dos fins. ${ }^{185}$

A discordância de Rawls é com a tradução em inglês para a Fundamentação da Metafísica dos Costumes, feita por Paton, para a formulação do reino dos fins: "todas as máximas que procedem de nossa ação legisladora no mundo devem harmonizar-se [segundo Paton] ou devem coerir-se [segundo Rawls] em um possível reino dos fins como um reino da natureza". Há que se reconhecer uma atividade que subjaz ao verbo "coerir", atividade esta que é um elemento importante na teoria rawlsiana. O reino dos fins perde seu status metafísico orientado à ética e torna-se um conceito marcadamente político. Andrews Reath ${ }^{186}$ e Christine Korsgaard ${ }^{187}$, bem como a maior parte dos nomes ligados de alguma maneira a John Rawls, são partidários desse tipo de leitura: que cada agente deve ter capacidade para ganhar a adesão de todos os membros dessa sociedade de fins ou, dito de outra maneira, devo escolher minha máxima de tal sorte que o outro a tome como sua também e assim construir uma legislação universal nessa comunidade de fins.

A dar apoio a essa tese, ainda é possível encontrar n'À paz perpétua uma referência direta a um mundo suprassensível cujo método de formulação é bastante assemelhado com aquele usado na Fundamentação da Metafísica dos Costumes para referir-se ao reino dos fins:

A validade dos direitos inatos inalienáveis e que pertencem necessariamente à humanidade é confirmada e elevada pelo princípio das relações jurídicas do próprio homem com entidades mais altas (quando ele as imagina), ao representar-se a si mesmo

\footnotetext{
${ }^{183}$ Katrin Flikschuh, "Kant's kingdom of ends: metaphysical, not political”, p. 119.

${ }^{184}$ Roger Sullivan, An introduction to Kant's ethics, p. 86.

${ }^{185}$ Como o problema se põe a partir da tradução do alemão para o inglês, acreditamos ser útil trazer o trecho original em inglês (RAWLS, 2000, p. 203): “(b) All maximsn as proceeding from our making of law ought to cohere into a possible realm of ends as a realm of nature. This translates Kant's words 'zuzammenstimmen ... zu einem möglichen Reiche der Zwecke' not as 'harmonize with' (Paton) but as 'cohere into'. I think that it is closer to Kant's thought, which is not that there is a realm of ends, already there, so to speak, with which our making of law must somehow harmonize. Rather, our making of law as we intelligently and conscientiously follow the principles of practical reason (as procedurally represented by the CI-procedure) constitutes, or constructs, the public moral law for a realm of ends. This thought will be important later when we come to Kant's moral constructivism".

${ }^{186}$ Cf. REATH, Andrews. Agency and autonomy in Kant's moral theory. Oxford: Clarendon Press, 2006, pp. 173196.

${ }^{187}$ Christine Korsgaard, 1996, pp. 188-224.
} 
segundo esses mesmos princípios também como um cidadão de um mundo suprassensível (ZeF, AA VIII:350).

É fato que o conceito de um reino suprassensível povoado por "cidadãos" de algum tipo está presente em toda a moral. O conceito mesmo de reino dos fins, tal como apresentado na Fundamentação da Metafísica dos Costumes, deve concernir à toda moral visto que a obra não é especificamente ética: se o conceito de autonomia puder valer para toda a matéria dos costumes (e efetivamente vale), então tal conceito fecundo que vem apenso ao princípio de autonomia deve valer igualmente para todo o campo dos costumes. Esse tipo de leitura enfrenta duas oposições: a primeira delas é levantada por Paul Guyer ${ }^{188}$, de que a descrição de Rawls do reino dos fins como uma "república moral" (moral commonwealth) é incompleta porque enfatiza um só aspecto do pensamento kantiano - a saber, apoia-se sobremaneira na noção da igualdade. Assim, Rawls não teria entendido ou, noutra via, teria preferido minimizar o caráter sistemático do reino dos fins. A segunda oposição ${ }^{189}$ é que Rawls faz uma confusão entre o mundo inteligível das obras de moral com aquele jurídico da Doutrina do Direito, dando proeminência ao direito para a realizar uma interpretação regressiva de toda a obra Kant. O ponto de diferença aqui é a natureza da lei: na Doutrina do Direito, a lei teria um caráter coercitivo, precisaria ser imposta e resguardada por instituições públicas que garantam uma sanção no caso de seu descumprimento; no caso ético, a lei é interna, fundada exclusivamente na liberdade da vontade (como bem o diz a primeira formulação do imperativo categórico: devo querer que a minha máxima se torne lei universal). Essa oposição passa ao largo da questão da lei permissiva, também expressa na Metafísica dos Costumes, e da polêmica interpretativa sobre o pertencimento ou não da doutrina do direito kantiano à moral sustentada pelo princípio supremo da moralidade (Willaschek nota a presença de deveres evidentemente jurídicos na Doutrina da Virtude o que, por si, contraria a visão do conceito de direito como restrito exclusivamente ao direito estrito).

\footnotetext{
${ }^{188}$ Paul Guyer, Kant, pp. 205-206.

${ }^{189}$ Cf. Katrin Flikschuh, "Kant's kingdom of ends: metaphysical, not political".
} 


\section{CONSIDERAÇÕES FINAIS}

À guisa de últimas palavras, voltamos a tratar das tensões do pensamento de Kant: de um lado, a tensão entre indivíduo e espécie; de outro lado, em certa medida decorrente da primeira, a tensão entre elementos liberais e elementos republicanos em sua doutrina. Com a divisão em três capítulos nos quais, em todos e gradativamente, foram abordados elementos da doutrina moral e da filosofia da história sempre adicionando um enfoque novo ao problema, esperamos haver mantido e transparecido a mesma tensão que se desenvolve ao largo do pensamento kantiano. Não foi nossa intenção privilegiar uma ou outra interpretação no tocante, especialmente, à questão da tensão entre os elementos liberais e republicanos da doutrina kantiana. Cabe retomar um ponto com o qual iniciamos a dissertação: a noção de autonomia é central e esperamos haver provado que é lícito falar em expressões de autonomia de acordo com o campo de saber a que nos referimos. Assim, de maneira abrangente, o princípio de autonomia é a capacidade de dar-se leis universalmente vinculantes; a mera capacidade de dar-se leis (sem que estas sejam universais porque fundadas alhures da razão pura) caracteriza, simplesmente, a situação no estado de natureza: a cada um era lícito fazer o que subjetivamente lhes parecia bom por seu próprio direito. A capacidade de dar-se leis universalmente vinculantes, contudo, muda sua expressão de acordo com a legislação que se refere: a legislação interna (ética) não necessitava de nenhum termo intermediário entre o legislador e o súdito, isto é, bastava a própria vontade legislando universalmente sua lei; com relação à legislação externa (jurídica), dois problemas se puseram — o primeiro deles é a questão da representação, isto é, entre o cidadão e a lei jurídica havia um termo intermediário (o representante parlamentar) sem o qual se tornaria impossível pensar uma forma de governo para os Estados Modernos; o segundo problema tem a ver a relação entre a teoria e a prática política, isto é, em compreender o que seria a política enquanto prática da doutrina do direito.

A definição de prática aparece inicialmente sendo trabalhada de maneira abstrata no Teoria e prática (especialmente esboçada como uma ligação entre a idealidade moral à realidade contingencial de uma dada sociedade), encontra sua forma final nos apêndices d'À paz perpétua: a política enquanto prática deve se vincular à moral. Ambos os problemas se entrecruzam novamente. Do ponto de vista da história, isto é, do ponto de vista da espécie há um constante progresso no gênero humano que não é propriamente moral, mas que guia à moralização. A pergunta crucial a ser posta é: qual o ponto de divisa entre o progresso que não é moral (mas condição facilitadora para a moralidade) e o progresso propriamente moralizador? Conseguir responder a essa pergunta, em nosso entender, é dar conta entre a tensão dos elementos liberais e 
dos elementos republicamos na doutrina kantiana; se o direito ou, dito noutras palavras, o estabelecimento do Estado, é um mecanismo natural (não propriamente signo da moralidade) e se é correto que o direito kantiano tenha preferencialmente maior carga de elementos liberais ao passo que a política tenho preferencialmente mais elementos republicanos e que a política, enquanto doutrina prática, não deva dar um passo adiante sem prestar homenagens à sua doutrina teórica (a moral), uma possível pista para a interpretação do problema está dada. A tensão é necessária. Só faz sentido uma teoria da política, falar em dispositivos como uso público da razão ou a fórmula transcendental do direito público que compreender a doutrina política como uma passagem propriamente dita: a passagem que a sociedade de homens sai da tutela da natureza e assume sua autodeterminação. Essa é uma tarefa intrinsicamente positiva, isto é, exige como condição essencial uma atividade dos homens - sua saída da menoridade em conjunto (passo que só pode se dar após alçada a condição primária de sociedade juridicamente organizada). 


\section{BIBLIOGRAFIA}

\section{Referências primárias}

KANT, Immanuel. Akademieausgabe von Immanuel Kants Gesammelten Werk, 29 vols. Berlin: Walter de Gruyter, 2005.

. À paz perpétua. Trad. Marco Zingano. Porto Alegre: L\&PM, 2011.

. “À paz perpétua: um projeto filosófico". In: A paz perpétua e outros opúsculos. Trad. Artur Morão. Lisboa: Edições 70, 2009, pp. 129-185.

. Crítica da Razão Pura. Trad. Fernando Costa Mattos. Petrópolis: Vozes, 2012.

Crítica da Razão Prática. Trad. Valério Rohden (ed. bilíngue). São Paulo: Martins Fontes, 2003.

Crítica do Juízo. Trad. Valério Rohden e António Marques. $2^{\mathrm{a}}$ ed. Rio de Janeiro: Forense Universitária, 2002.

Conflito das Faculdades. Trad. Artur Morão. Lisboa: Edições 70, 1993.

. Fundamentação da Metafísica dos Costumes. Trad. Guido Antônio de Almeida. São Paulo: Barcarola, 2009.

Ideia de uma história universal de um ponto de vista cosmopolita. Trad.

Ricardo Terra e Rodrigo Naves. São Paulo: Martins Fontes, 2011.

Metafísica dos Costumes. Trad. Clélia Aparecida Martins. Rev. téc. Bruno

Nadai, Diego Kobisbau, Fernando Costa Mattos, Monique Hulshof, Nathalie Bressiani e Ricardo Terra. Petrópolis: Editora Vozes, 2013, pp. 09-178.

. "Resposta à pergunta: que é Esclarecimento?". In: Textos seletos. Ed. bilínguie. Trad. Floriano de Souza Fernandes. Petrópolis: Vozes, 2005 ( $\left.3^{\mathrm{a}} \mathrm{ed}\right)$.

Resposta à pergunta: o que é o Esclarecimento? Trad. Luiz Paulo Rouanet.

Brasília: Casa das Musas, 2008.

. “Resposta à pergunta: que é o Iluminismo?”. In: A paz perpétua e outros

opúsculos. Trad. Artur Morão. Lisboa: Edições 70, 2009. 
"Sobre a expressão corrente: isso pode ser correcto na teoria, mas nada vale na prática”. In: A paz perpétua e outros opúsculos. Trad. Artur Morão. Lisboa: Edições 70, 2009, pp. 59-109.

- "Sobre um suposto direito de mentir por amor à humanidade". In: A paz perpétua e outros opúsculos. Trad. Artur Morão. Lisboa: Edições 70, 2009, pp. 187-194.

\section{Referências secundárias}

ALBRECHT, Michael. "Kant's Justification of the Role of Maxims in Ethics". In: HÖFFE, O. (org.) Kant's moral and legal philosophy. Cambridge: Cambridge University Press, 2009, pp. 134-155.

ALISSON, Henry. Kant's theory of freedom. New York: Cambridge University Press, 1990.

ARENDT, Hannah. Lectures on Kant's political philosophy. Chicago: The University of Chicago Press, 1992.

BECK, Lewis White. A commentary on Kant's Critique of Practical Reason. Chicago: University of Chicago Press, 1984.

BERTEN, André. "A compatibilidade do republicanismo kantiano com o modelo do contrato social". In: SANTOS, L. R.; ANDRÉ, J. G. (orgs.) Filosofia kantiana do direito e da política: seminário internacional. Lisboa: Universidade de Lisboa, 2007.

BITTNER, Rüdiger. “Máximas”. In: Studia Kantiana, vol. 5, 2004, pp. 7-25.

BOBBIO, N. O futuro da democracia. São Paulo: Paz e Terra, 1997.

Direito e poder. São Paulo: UNESP, 2008.

. Direito e Estado no pensamento de Emanuel Kant. São Paulo: Mandarim, 2000.

BUBNER, Rüdiger. “Another look at maxims”. In: CICOVACKI, Pedrog. Kant's legacy: essays in honor of Lewis White Beck. Rochester: University of Rochester Press, 2000, pp.245259.

CAIMI, Mario. La Metafísica de Kant. Buenos Aires: UBA, 1989.

CASSIRER, Ernst. Kant's life and thought. New Haven: Yale University Press, 1981.

CAVALLAR, Georg. “Cosmopolitanisms in Kant's philosophy”. In: Ethics \& Global Politics, vol. $5, n^{\circ} 2,2012$, pp. 95-118. 
DELBOS, Victor. La philosophie pratique de Kant. $3^{\mathrm{a}}$ ed. Paris: Presses Universitaires de France, 1969.

FLIKCHUH, K. “Kant's kingdom of ends: metaphysical, not political”. In: TIMMERMANN, J. Groundwork of the Metaphysics of Morals: a critical guide. Cambridge: Cambridge University Press.

GOYARD-FABRE, S. La Philosophie du Droit de Kant. Paris: Vrin, 1996.

GALVÃO, Pedro. "Introdução". In: KANT, Immanuel. Fundamentação da Metafísica dos Costumes. Lisboa Edições 70, 2009.

GERHARDT, Volker. "Uma teoria crítica da política sobre o projeto kantiano À paz perpétua" In: ROHDEN, Valério. Kant e a instituição da paz. Porto Alegre: Editora da UFRGS, 1997.

GUYER, Paul. "Kant's deductions of the principles of Right”. In: TIMMONS, Mark. (org.) Kant's Metaphysics of Morals: interpretative essays. New York: Oxford University Press, 2004.

Kant. Abingdon: Routledge, 2006.

GRANATO, Marcelo de Azevedo. O caminho pelo público: uma análise conceitual, sistemática e atual do 'segundo' princípio transcendental do direito público, enunciado por Immanuel Kant. Tese de doutorado. Faculdade de Direito. USP, 2013.

HAAKONSSEN, K. "Republicanism" In: GOODIN, R.; PETTIT, P.; POGGE, T. (eds.) A companion to contemporary political philosophy. $2^{\mathrm{a}}$ ed. Oxford: Blackwell, 2012, pp. 729-736.

HABERMAS, Jürgen. Direito e democracia: entre factibilidade e validade. Rio de Janeiro, 1997. . "Três modelos normativos de democracia" In: Lua Nova, nº 36, 95, pp. 39-53. . “\$13 - A publicidade como princípio de mediação entre a política e a moral”. In: Mudança estrutural da esfera pública. Trad. Denílson Luiz Werle. São Paulo: Editora da UNESP, 2011, pp. 264-287.

HASSNER, Pierre. "Situation de la philosophie politique chez Kant". In: WEIL, Eric. (org.) Annales de philosophie politique $n^{0}$ 4: la philosophie politique de Kant. Paris: Presses Universitaires de France, 1962, pp. 77-103.

HÖFFE, Ottfried. "O imperativo categórico do direito: uma interpretação da Introdução à Doutrina do Direito". In: Studia Kantiana, nº 1, 1998. 
Immanuel Kant. São Paulo: Martins Fontes, 2005.

. "The Form of the Maxim as the Determining Ground of the Will (The Critique of Practical Reason: §§4-6, 27-30)". In: HÖFFE, O. (org.) Kant's moral and legal philosophy. Cambridge: Cambridge University Press, 2009, pp. 159-178.

KELSEN, Hans. Teoria Pura do Direito. São Paulo: Martins Fontes, 2004.

KLEINGELD, Pauline. "Kant, History and the idea of Moral devevolpment". In: History of Philosophy Quarterly, vol 16, nº 1, 1999, pp. 59-80.

"Kant, história e a ideia de desenvolvimento moral" In: Cadernos de Filosofia Alemã, vol. XVIII, jul-dez/2011, pp. 105-132.

KLEMME, Heiner. "A liberdade do arbítrio e o domínio do mal: a doutrina de Kant do mal radical entre moral, religião e direito". In: Studia Kantiana, nº 15, 2013, pp. 5-37.

KORSGAARD, Christine. Creating the kingdom of ends. Cambridge: Cambridge University Press, 1996.

LAURSEN, J. C. "The subversive Kant: the vocabular of 'public' and 'publicity". In: Political Theory, vol. 14, n 4, 1986, pp. 438-455.

LEBRUN, Gerard. Kant e o fim da metafísica. São Paulo: Martins Fontes, 2002.

LINDEN, Harry van der. Kantian ethics and socialism. Indianapolis: Hackett Publishing Company, 1988.

LONGUENESSE, Beatrice. Kant on the human standpoint. Cambridge: Cambridge University Press, 2005.

MARCOS, Maximiliano Hernández. "Política y antropología en Kant”. In: SANTOS, Leonel Ribeiro; ANDRÉ, José Gomes. Filosofia kantiana do direito e da política: seminário internacional. Lisboa: Universidade de Lisboa, 2007, pp. 65-100.

NADAI, Bruno. Progresso e moral na filosfia da história de Kant. Tese (Doutorado) Faculdade de Filosofia, Letras e Ciências Humanas. Departamento de Filosofia. USP, 2011.

"A moralidade no mundo: o sumo bem e a filosofia da história kantiana". In: Cadernos de Filosofia Alemã, n ${ }^{\text {a }}$ 20, jul-dez/2012, pp. 55-80.

NOUR, Soraya. À paz perpétua de Kant. São Paulo: Martins Fontes, 2004.

O’NEILL, Onora. Constructions of reason. Cambridge: Cambridge University Press, 1989. 
Bounds of Justice. New York: Cambridge University Press, 2000.

. "Kant and the social contract tradition". In: ELLIS, Elisabeth. (org.) Kant's

political theory: interpretations and applications. University Park: Pennsylvania State University Press, 2012.

“Autonomia, pluralidade e razão pública”. In: Cadernos de Filosofia Alemã, v. 19, n. 1, jan-jun 2014, pp. 15-34.

PATON, Herbert James. The categorical imperative. Philadelphia: University of Pennsylvania Press, 1971.

PERES, Daniel Tourinho. Kant: metafísica e política. Salvador: EDUFBA/UNESP, 2004.

PHILONENKO, Alexis. "Souveranité et legitimité chez Kant et Fichte”. In: Études kantiennes. Paris: Vrin, 1982.

Theorie et Praxis dans la pensée de Kant et Fichte en 1793. Paris: Vrin, 2000.

POGGE, Thomas. “Is Kant's Rechtslehre a 'comprehensive liberalism'?”. In: TIMMONS, Mark (org.) Kant's Metaphysics of Morals: interpretative essays. Oxford: Oxford University Press, 2002, pp. 133-158.

RAWLS, John. História da Filosofia Moral. São Paulo: Martins Fontes, 2005.

Lectures on the history of moral philosophy. Cambridge: Harvard University Press, 2000.

REATH, Andrews. Agency and autonomy in Kant's moral theory. Oxford: Clarendon Press, 2006.

RENAULT, Alain. Kant aujourd'hui. Paris: Flammarion, 1997.

RILEY, Patrick. "On Kant as the most adequate of the social contract theorists". In: Political Theory, vol. 1, no 4 (nov./1973), pp. 450-471.

RIPSTEIN, Arthur. "Kant and the circunstances of Justice”. In: ELLIS, Elisabeth. (org.) Kant's political thought: interpretations and applications. University Park: Pennsylvania State University, 2012.

ROHDEN, Valério. Kant e a instituição da paz. Porto Alegre: Editora da UFRS, 1997.

ROUANET, Luiz Sérgio. A paz perpétua: estudo sobre o pensamento político kantiano. Dissertação (mestrado). - Faculdade de Filosofia, Letras e Ciências Humanas. Departamento de Filosofia. USP, 1993. 
SAINT-PIERRE, Abbé de. Projet pour rendre la paix perpétuelle en Europe. Disponível em: <http://www.calameo.com/read/0020594285a4ea192fbe7>. Acesso em: 19/09/2015.

SANTOS, Leonel Ribeiro. Metáforas da razão. Lisboa: Fundação Calouste Gulbenkian, 1994. . "Da linguagem jurídica da filosofia crítica à arqueologia da razão prática". In: SANTOS, Leonel Ribeiro; ANDRÉ, José Gomes. Filosofia kantiana do direito e da política: seminário internacional. Lisboa: Universidade de Lisboa, 2007, pp.205-223 . "Kant: da reinvenção do republicanismo à ideia de uma 'república mundial'". In: Cadernos de Filosofia Alemã, vol. XVI, nº 1, jul-dez/2010.

SCHALK, Fritz. (org.) Französische Moralisten: La Rochefoucauld, Vauvenargues, Montesquieu, Chamfort. Zurich: Diogenes, 1995.

SCHNEEWIND, Jerome B. The invention of autonomy. New York: Cambridge University Press, 1998.

TERRA, Ricardo Ribeiro. A política tensa. São Paulo: Iluminuras, 1995. . Kant e o Direito. Rio de Janeiro: Jorge Zahar Editor, 2004. . "Juízo político e prudência em À paz perpétua". In: ROHDEN, Valério. (org.) Kant e a instituição da paz. Porto Alegre: Editora da UFRGS, 1997, pp. 222-232.

TRENTANI, Federica. “A política como realização do projeto da razão prática”. In: Studia Kantiana, $n^{\circ}$ 16, 2004, pp. 91-104.

TREVISAN, Diego Kobisbau. A Metafísica dos Costumes: a autonomia para o ser humano. Dissertação (Mestrado) - Faculdade de Filosofia Letras e Ciências Humanas. Departamento de Filosofia, Universidade de São Paulo, 2011

WEBB, Clement Charles Julian. Kant's philosophy of religion. Oxford: Clarendon Press, 1926. WILLASCHEK, Marcus. "Porque a doutrina do direito não pertence à metafísica dos costumes: algumas distinções básicas na filosofia moral de Kant”. In: TRAVESSONI, Alexandre. (org.) Kant e o Direito. Belo Horizonte: Mandamentos, 2009.

"Which imperatives for Right? On the non-prescriptive character of juridical laws in Kant's Metaphysics of Morals". In: TIMMONS, Mark. (org.) Kant's Metaphysics of Morals: interpretative essays. New York: Oxford University Press, 2004. 
WILLIAMS, Howard. "Liberty, equality and independence: core concepts in Kant's political philosophy". In: BIRD, G. (org.) A companion to Kant. Oxford: Blackwell Publishing Ltd, 2006, pp. 365-366.

WOOD, Allen. "The final form of Kant's practical philosophy". In: TIMMONS, Mark. (org.) Kant's Metaphysics of Morals: interpretative essays. New York: Oxford University Press, 2004.

YOVEL, Yarmiyahhu. Kant et la philosophie de l'histoire. Paris: Meridièns Klincksieck, 1989. ZINGANO, Marco. Razão e história em Kant. São Paulo: Brasiliense, 1988.

\section{Bibliografia consultada}

ALLISON, H. Idealism and freedom. Cambridge: Cambridge University Press, 1996. " Kant on freedom of the will". In: GUYER, P. (org.) The Cambridge Companion to Kant and Modern Philosophy. Cambridge: Cambridge University Press, 2007.

ALMEIDA, G. A. "Introdução". In: Fundamentação da Metafísica dos Costumes. São Paulo: Barcarolla, 2009. . "Liberdade e moralidade segundo Kant”. In: Analytica, vol. 2, n 1, 1997. . "Sobre o Princípio e a Lei Universal do Direito em Kant”. In: Kriterion 14.

2006.

BOBBIO, Norberto. "Deux notions de la liberté dans la pensée politique de Kant". In: WEIL, E. (org) La philosophie politique de Kant. Paris: Presses Universitaires de France, 1962, pp. 105-118.

. Direito e poder. São Paulo: Editora da UNESP, 2006. O futuro da democracia. São Paulo: Paz e Terra, 1997

BOHMAN, J.; LUTZ-BACHMANN, M. (orgs.). Perpetual peace: essays on Kant's cosmopolitan ideal. MIT Press, 1997.

CICOVACKI, P. (org.) Kant's legacy: essays in honor of Lewis White Beck. Rochester: University of Rochester Press, 2000. 
CONSTANT, Benjamin. De la liberté des Anciens comparée à celle des Modernes. Paris: Mille et une nuits, 2010.

DELBOS, Victor. Kant. São Paulo: Cultura Moderna, 194-?

DERRIDA, J. "O direito à filosofia de um ponto de vista cosmopolítico". In: GUINSBERG, J. (org.) A paz perpétua: um projeto para hoje. São Paulo: Perspectiva, 2004, pp. 11-29.

FLIKSCHUH, K. Kant and Modern Political Philosophy. Cambridge: Cambridge University Press, 2000.

GIANNOTTI, José Artur. "Kant e o espaço da história universal”. In: KANT, I. Ideia de uma história universal de um ponto de vista cosmopolita. São Paulo: Martins Fontes, 2011.

HERMAN, B. "A Cosmopolitan Kingdom of Ends". In: HERMAN, B.; KORSGAARD, C. M.; REATH, A. (eds) Reclaiming the history of ethics: essays for John Rawls. Cambridge, Cambridge University Press, 1997.

HÖFFE, Otfried. Kant's cosmopolitan theory of Law and Peace. New York: Cambridge University Press, 2006.

HOLTMAN, S. “Autonomy and Kingdom of Ends”. In: HILL JR, T. E. The Blackwell Guide to Kant's Ethics. Oxford: Blackwell Publishing, 2009.

HORN, C.; SCHÖNECKER, D. (org.) Groundwork for the Metaphysics of Morals. Berlin: Walter de Gruyter, 2006.

KELSEN, Hans. Teoria geral do Direito e do Estado. São Paulo: Martins Fontes, 2000.

KERSTING, W. "The civil constitution in every state shall be a Republican One". In: AMERIKS, K.; HÖFFE, O. (org.) Kant's moral and legal philosophy. Cambridge: Cambridge University Press, 2009.

KERVÉGAN, Jean-François. "La théorie kantienne de la normativité" In: KERVÉGAN, J-F. (org) Raison pratique et normativité chez Kant. Lyon: ENS Éditions, 2010, pp. 89-109.

LEBRUN, Gerard. "Uma escatologia para a moral”. In: KANT, I. Ideia de uma história universal de um ponto de vista cosmopolita. São Paulo: Martins Fontes, 2011.

LISSER, K. El concepto del derecho en Kant. México: Centro de Estúdios Filosóficos, Universidad Autónoma de México, 1959.

REATH, A. "Legislating for a Realm of Ends: the social dimension of autonomy”. In: HERMAN, B.; KORSGAARD, C. M.; REATH, A. (org.) Reclaiming the history of ethics: essays for 
John Rawls. Cambridge, Cambridge University Press, 1997.

ROMANO, R. "Ensaio para um posfácio". In: GUINSBERG, J. (org.) A paz perpétua: um projeto para hoje. São Paulo: Perspectiva, 2004, 101-153.

ROSENFELD, A. "O problema da paz universal: Kant e as Nações Unidas". In: GUINSBERG, J. (org.) A paz perpétua: um projeto para hoje. São Paulo: Perspectiva, 2004, pp. 89-99.

SCHNEEWIND, J. B. “Autonomy, obligation, and virtue. An overview of Kant's moral philosophy". In: GUYER, P. (org.) The Cambridge Companion to Kant. Cambridge: Cambridge University Press, 1999.

TERRA, Ricardo Ribeiro. "História universal e direito em Kant". In: Revista Discurso, no 34, 2004, pp. 09-32.

TIMMERMANN, J. (org) Kant's Groundwork of the Metaphysics of Morals: a critical guide. New York: Cambridge University Press, 2009.

WOOD, A. Kant's Ethical Thought. Cambridge: Cambridge University Press, 1999. . "Kant's Project for Perpetual Peace”. In: CHEAH, P.; ROBBINS, B. (orgs.) Cosmopolitics: thinking and feeling beyond the nation. Minneapolis: University of Minnesota Press, 1998.

. "Kant's formulations of the Moral Law". In: BIRD, G. (ed.) A companion to Kant. Oxford: Blackwell Publishing Ltd, 2006, pp. 291-307.

. "General introduction". In: KANT, I. Practical Philosophy. New York: Cambridge, 1996. 